\title{
Assessing the Economic Impact of North-South Free Trade Agreements \\ ---- China-New Zealand Free Trade Agreement and \\ China-Australia Free Trade Agreement
}

By

\author{
Jinzhu ZHOU
}

A Thesis

Submitted to Victoria University of Wellington in Fulfilment of the Requirements for the Degree of

Master of Arts

In

International Relations

School of History \& Philosophy \& Political Science \& International Relations

Victoria University of Wellington

25 January 2010 


\section{Abstract}

This research develops a model of assessing the economic impact of free trade agreements (FTAs) between developed countries and developing countries (north-south FTAs). This model goes beyond the conventional studies that use static effects in traditional gains as primary indicators of the economic impact, and incorporates dynamics effects as well as non-traditional gains for a more accurate assessment. The research uses China's north-south FTAs, namely, China's FTA with New Zealand - the first comprehensive FTA that China has signed with a developed country - and the proposed FTA between China and Australia. Both cases provide an ideal empirical basis for testing the proposed model.

After introduction of the research problem, design and methodology, Part I of the study provides a general discussion of the FTAs between China and New Zealand, and China and Australia as a background to the research. Part II starts with the conventional model of traditional gains. It first demonstrates how the static effect of the north-south FTA is analyzed in Robson's three-country model. It shows that in his model, the trade creation effect is dominant in the free trade area. The study then introduces the concept of dynamic effect of traditional gains. The study first uses the Revealed Comparative Advantage (RCA) index to analyse the competition effect of trade in goods by industries among China, New Zealand and Australia. It then discusses the competition effect of trade in services in categories through Trade Competitive Power (TC) indexes. The study further examines the effect of investment creation after the China-New Zealand FTA and China-Australia FTA entered into force. The findings of this section on the dynamic effect are that China would 
have negative impact on cattle husbandry, forestry, mining and some categories of services which are also the industries that New Zealand and Australia would further develop in China's market.

In Part III, the study discusses non-traditional gains as important indicators of the economic impact of FTAs. It incorporates the hub \& spoke theory (H\&S) with Regional Trade Agreements (RTAs) strategies of China, New Zealand and Australia. The study shows that the north-south FTAs are important components for both developed countries and developing countries' RTAs strategies. The China-New Zealand FTA and the proposed China-Australia FTA are the wedges between China and the advanced economies system. Meanwhile, the China-New Zealand FTA will be a model for future north-south FTAs involving China.

This thesis contributes to our understanding of the complicated and dynamic relationship between FTAs among countries of different levels of economic development and their overall economic growth and development. It also adds to our knowledge about how this relationship can be better analyzed and explained.

Key Words: North-South FTA, China, New Zealand, Australia, traditional gains, non-traditional gains. 
Contents

List of Figures and Tables

Abbreviations 


\section{Contents}

1 INTRODUCTION

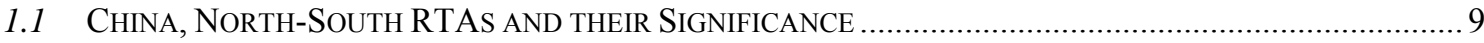

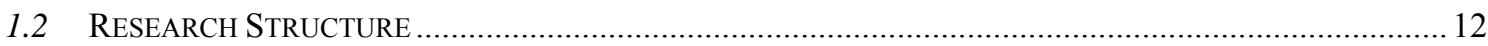

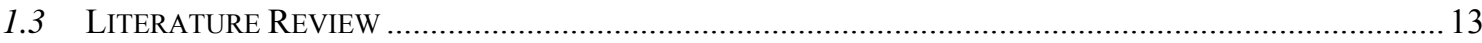

1.3.1 Economic Research and the Theory of Traditional Gains .................................................. 13

1.3.2 Economic Research and the Theory of Non-Traditional Gains ............................................. 18

1.4 Methodology, CONTRIBUtions AND LiMitATIONS OF THIS RESEARCH.....................................22

2 THE CHINA-NEW ZEALAND FTA AND THE CHINA-AUSTRALIA FTA ........................ 26

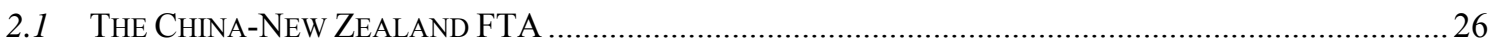

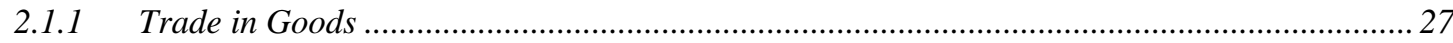

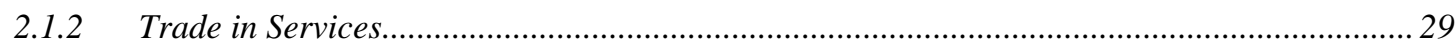

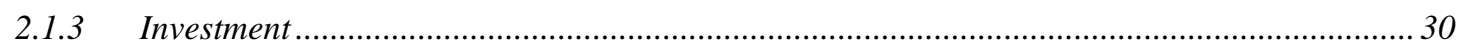

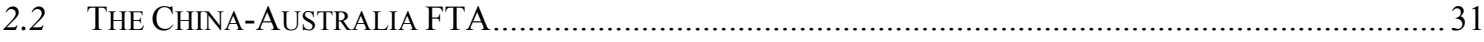

2.3 The TRAdE STATUS QUO AMONG ChinA, NEW ZEALAND AND AUSTRALIA ..................................... 32

3 TRADITIONAL GAINS OF NORTH-SOUTH FTAS ........................................................... 35

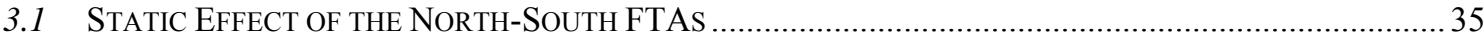

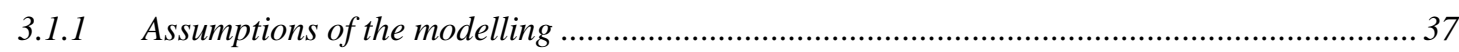

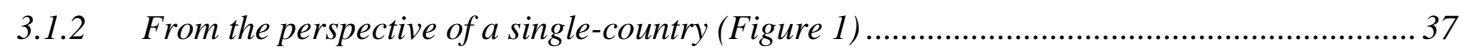

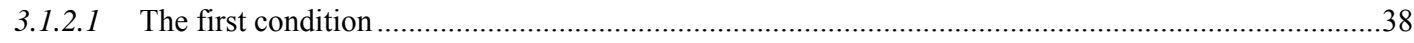

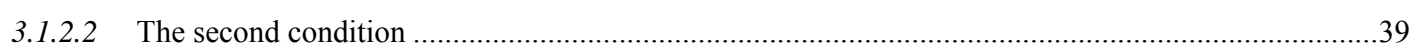

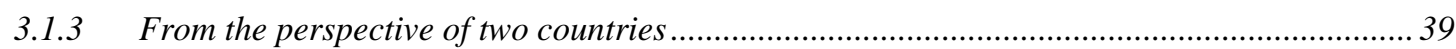

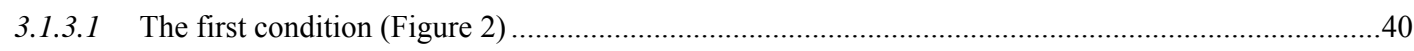

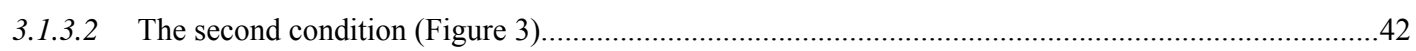

3.2 DynAmic EFFECT OF THE ChinA-NEW ZEALAND FTA AND THE CHINA-Australia FTA ...............44

3.2.1 Competitive Effect of Trade in Goods.................................................................................... 44

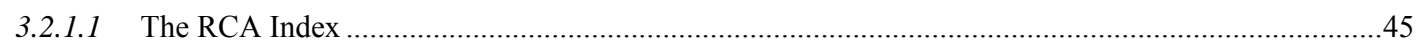

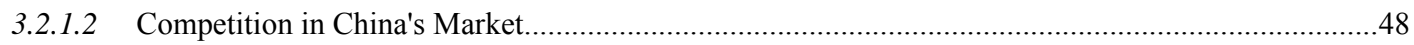

3.2.1.3 Competition in New Zealand's Market.....................................................................................56

3.2.1.4 Competition in Australia's Market...............................................................................................61

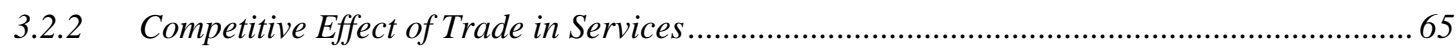

3.2.2.1 Status Quo Trade in Services: China, New Zealand and Australia.....................................................67

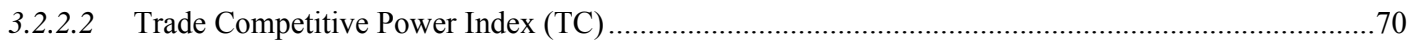

3.2.3 Investment Creation among China, New Zealand and Australia ......................................... 75

3.2.3.1 Investment status quo among China, New Zealand and Australia.....................................................76

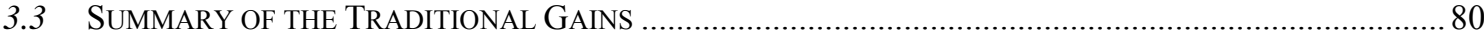

4 NON-TRADITIONAL GAINS OF THE CHINA-NEW ZEALAND FTA AND THE

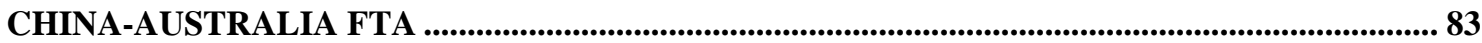

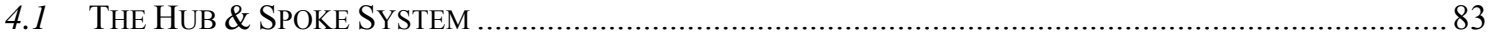

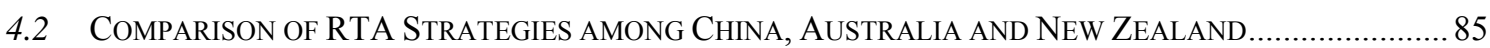

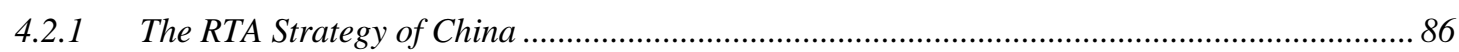

4.2.1.1 The requirement of diplomacy with important surrounding neighbours ..........................................89 
4.2.1.2 Establishing long-term and reliable energy and resource supply relationships ...............................91

4.2.1.3 Coordinating the "Going Out" strategy ...........................................................................................93

4.2.2 The RTA Strategies of Australia and New Zealand............................................................. 94

4.2.3 The RTA Web of China, Australia and New Zealand.......................................................... 98

4.3 The InSURANCE EFFECT OF THE CHINA-NEW ZEALANd FTA AND THE CHINA-Australia FTA

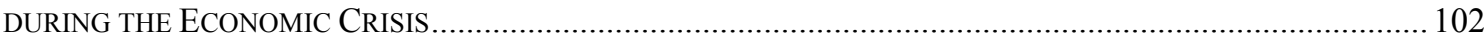

4.4 The Meaning of the ChInA-New Zealand FTA And the ChinA-Australia FTA................... 104

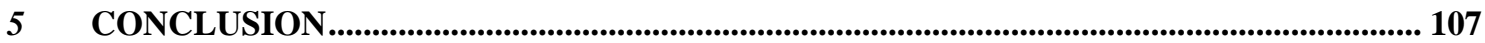

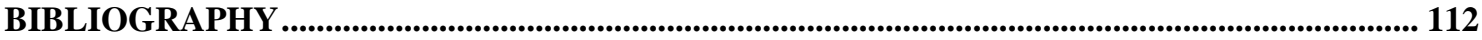

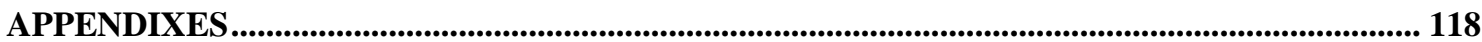

APPENDIX 1 MAJOR EXPORTS FROM NEW ZEALAND TO CHINA BY COMMODITY (HS 2002)............... 117

APPENDIX 2 MAJOR IMPROTS OF NEW ZEALAND FROM CHINA BY COMMODITY (HS 2002)................ 119

APPENDIX 3 MAJOR EXPORTS FROM AUSTRALIA TO CHINA BY COMMODITY (HS 2002) .................... 121

APPENDIX 4 MAJOR IMPORTS OF AUSTRALIA FROM CHINA BY COMMODITY (HS 2002) .................... 123

APPENDIX 5 MAJOR EXPORTS FROM NEW ZEALAND TO AUSTRALIA BY COMMODITY (HS 2002) ....... 125

APPENDIX 6 MAJOR IMPORTS OF NEW ZEALAND FROM AUSTRALIA BY COMMODITY (HS 2002)........ 127

APPENDIX 7 ORIGINAL DATA FOR RCA INDEX

EXPORTS TO THE WORLD BY COMMODITY (HS 2007) AND COUNTRY IN 2007 (1)............... 129

APPENDIX 8 EXPROTS TO THE WORLD BY COMMODITY (HS 2007) AND COUNTRY IN 2007 (2) .......... 130

APPENDIX 9 EXPORTS TO THE WORLD BY COMMODITY (HS 2007) AND COUNTRY IN 2007 (3) .......... 131

APPENDIX 10 ORIGIONAL DATA FOR TC INDEX

EXPORTS AND IMPORTS OF SERVICES BY COUNTRY IN 2006 ............................................. 132

APPENDIX 11 EXPORTS AND IMPORTS OF SERVICES BY COUNTRY IN 2005 ...................................... 133 


\section{List of Figures and Tables}

FIGURE 1 THE STATIC EFFECTS OF A FTA ON A SINGLE COUNTRY …................................................ 1

Figure 2 The Static EFFEct Of A FTA on Two CounTries (A) ..................................................... 41

Figure 3 The Static EFFEct Of A FTA on Two CounTries (B) ....................................................... 1

Figure 4 COMPARISONS OF H\&S AND "Global FreE TradE" Mode ................................................... 1

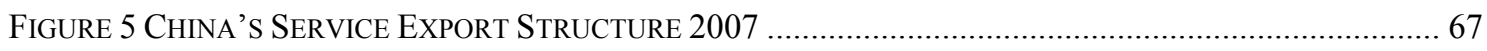

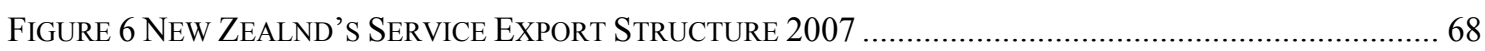

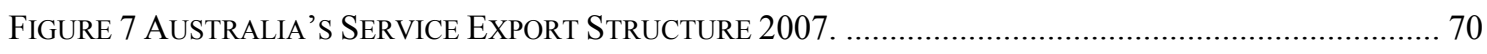

Figure 8 RTAs WEB Of ChINA, AUSTRALIA AND NEW ZEALAND ..................................................... 1

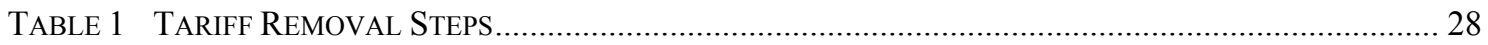

TABle 2 EXPORT AND IMPORT AMONG ChINA, NEW ZEALAND AND Australia In 2007 ....................... 33

TABLE 3 EXPORT FROM NEW ZEALAND TO CHINA IN HS CODE 2003-2007.........................................49

TABLE 4 RCA INDEXES OF NEW ZEALAND AND CHINA ON CHINA'S MARKET 2007 .............................. 50

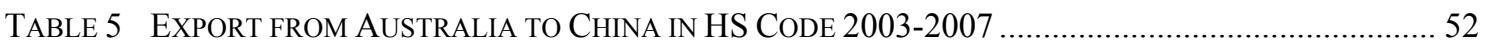

TABLE 6 RCA INDEXES OF AUSTRALIA AND CHINA ON CHINA's MARKET 2007.................................. 52

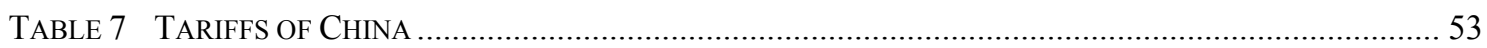

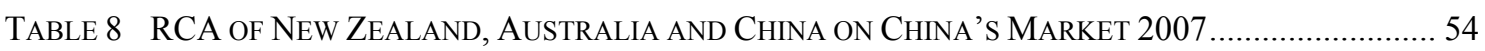

TABLE 9 EXPORT FROM CHINA TO NEW ZEALAND IN HS CODE 2003-2007...........................................5

TABle 10 RCA IndeXes of ChInA AND NeW ZEALAND ON NEW ZEALAND'S Market 2007................ 58

TABLE 11 EXPORTS FROM AUSTRALIA TO NEW ZEALAND IN HS CODE 2003-2007 ..............................59

Table 12 RCA IndeXes of China, Australia AND New ZEAland on New Zealand's Market 2007

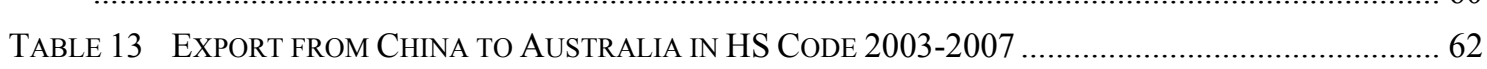

TABLE 14 RCA INDEXES OF ChINA AND Australia ON AUSTRALIA's MARKET 2007...........................62

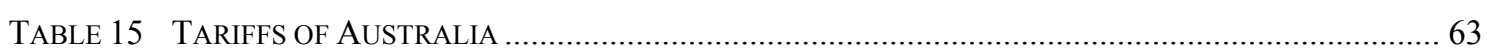

TABle 16 TC IndeXes of ChINA, NeW ZEALAND AND Australia By SERViCES Categories ............. 72

TABLE 17 ChINA'S OUTWARd FDI Flows TO Australia AND NEW ZEALAND.................................... 78

TABLE 18 CHINA'S OUTWARD FDI STOCKS TO AUSTRALIA AND NEW ZEALAND ................................... 78

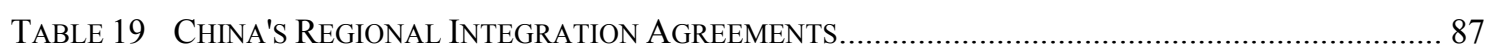

TABLE 20 AUSTRALIA'S REGIONAL INTEGRATION AGREEMENTS..........................................................9. 95

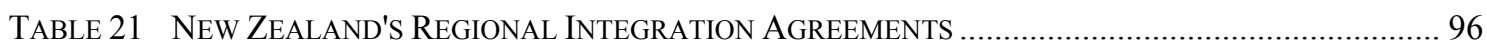




\section{Abbreviations}

ASEAN

Association of Southeast Asian Nations

CER

Closer Economic Relations between Australia and New Zealand

FDI

Foreign Direct Investment

FTA

Free Trade Agreement

GATS

General Agreement on Trade in Service

GATT

General Agreement on Trade and Tariffs

GCC

Cooperation Council for the Arab States of the Gulf

GDP

Gross Domestic Product

HS

Harmonized Commodity Description and Coding System

$\mathrm{H} \& \mathrm{~S}$

Hub \& Spoke

MOFCOM China Ministry of Commerce

NZMFAT New Zealand Ministry of Foreign Affairs and Trade

OECD Organization for Economic Co-operation and Development

RCA Revealed Comparative Advantage

RTA Regional Trade Agreement

SCO Shanghai Cooperation Organization

TC Trade Competitive Power

UN Comtrade United Nations Commodity Trade Statistics Database

WTO World Trade Organization 


\section{Introduction}

\subsection{China, North-South RTAs and their Significance}

The China-New Zealand Free Trade Agreement (FTA) is the first north-south FTA ${ }^{1}$ for China and its economic impact draws the attention of scholars, business leaders and the public in both countries and around the world. The FTA between China and Australia, both large economies with important status in the Asia-Pacific region, is as of early 2009 still under negotiation. The China-Australia FTA, which is of a larger economic scale than the China-New Zealand FTA, will probably be the second north-south FTA for China. Considering this and the existence of Closer Economic Relations (CER) between Australia and New Zealand, it is clear that a "global free trade" mode is being created between the Chinese, New Zealand and Australian economies. The economic impacts of the north-south FTAs to China are comprehensive as combined analyses of the China-New Zealand FTA and the China-Australia FTA show.

There has been a surge in regional trade integration all over the world since the early 1990s. Some 421 regional trade agreements (RTAs) had already been notified to the GATT/WTO by December 2008 and 230 of them have already entered into force. Of these RTAs, free trade agreements (FTAs) and partial scope agreements account for over $90 \%$ of the agreements, while customs unions account for less than 10\% (WTO 2009). In recent times, FTAs have been the preferred option as compared to customs unions they provide more freedom and greater preservation of economic sovereignty. In this new round of regional

1 'North' here refers to a developed country and 'south' to a developing country. 
trade integration since the 1990 s, developing countries have increasingly been interested in north-south trade agreements. This trend is an interesting puzzle considering that these asymmetric north-south FTAs do not satisfy the conditions of traditional regional trade integration theories. Traditional theories argue that the RTAs should be signed between members with similar levels of economic conditions, north to north or south to south. So far there is no one successful north-south RTA of a large economic scale in the Asia-Pacific region. For this reason China's FTA with New Zealand and the proposed FTA between China and Australia represent a unique case study of north-south RTAs. Moreover, as the biggest developing country in the world, these two north-south FTAs are not only important to China but also to China's developed partners, New Zealand and Australia.

This research groups the China-New Zealand FTA and the Australia-China FTA together for two reasons. Firstly, the "global free trade" mode among China, New Zealand and Australia makes the economic effects of each FTA un-separable. ${ }^{2}$ The economic effects of these two north-south FTAs with China affect each other. Secondly, China chose New Zealand as the first developed partner to sign an FTA with as a trial. When choosing New Zealand, not only New Zealand's small economic scale was considered but also New Zealand's international status and especially its special economic relationship with Australia. The geographic location of Australia and New Zealand and the Closer Economic Relations (CER) trade agreement may decrease the possibility of a trade diversion effect among China, New Zealand and Australia. Therefore, this research groups the New

\footnotetext{
${ }^{2}$ The "global free trade" mode is formed by three FTAs (Australia-New Zealand CER, China-New Zealand FTA and China-Australia FTA). In the mode every country implements free trade with each other.
} 
Zealand-China FTA and the currently being negotiated Australia-China FTA together to provide a more accurate assessment of the economic impact of China's north-south trade agreements.

This research approaches economic analyses of the north-south FTAs from two perspectives, traditional gains and non-traditional gains. This research focuses on the dynamic effect and the non-traditional gains of the China-New Zealand FTA and the proposed China-Australia FTA. Existing research about north-south FTAs and China mainly study the static effects and neglect the dynamic effects and non-traditional gains. However, for China with one of the biggest markets in the world, the trade creation effect and the trade diversion effects (traditional focus) are hypothesised to be less important in comparison to the dynamic effects and the non-traditional gains of the trade agreement. Traditional gains of an FTA mainly refer to the observable benefits obtained from increased trade, competition and investment. Traditional gains include the Static Effect and the Dynamic Effect which are usually used to measure benefit allocation between members. Non-traditional gains on the other hand refer to policy benefits derived from international cooperation between FTA members. Non-traditional gains explore the economic effects of an FTA from a new perspective of international political economy. Furthermore, non-traditional gains provide a powerful explanatory tool to show the reasons why developing countries sign RTAs with major economies even when the developing countries are not likely to benefit from the FTA in terms of traditional gains. 
In summary, this thesis researches north-south RTAs and uses the recently signed FTA between China and New Zealand and the proposed FTA between China and Australia as case studies to analyse the traditional and non-traditional gains. The focus of the research is on presenting data to show the combined effect of these trade agreements and to compare the traditional and non-traditional gains. It is hypothesised that whilst the traditional benefits for China are negative or non-significant, the non-traditional dynamic effects of this set of north-south agreements are significant and provide an explanation of why China has entered into this "global free trade" mode with New Zealand and Australia. This research aims to contribute to the overall understanding of north-south RTAs by including non-traditional gains as part of the analysis and aims to provide some understanding of possible future trends for China's willingness to sign RTAs with developed countries in the future and to the study of north-south RTAs in general.

\subsection{Research Structure}

This research is organized as follows. Chapter 1 introduces the significance of the topic and the methodology. This chapter also summarizes and critiques the regional trade theories and reviews research on the China-New Zealand FTA and the China-Australia FTA. Chapter 2 provides an introduction to the China-New Zealand FTA and the China-Australia FTA. Chapter 3 explains the traditional gains of the China-New Zealand FTA and the China-Australia FTA over two aspects, the static effect and the dynamic effect. The first section of this chapter analyses the static effect of the north-south FTA in general by using Robson's (1980) three-country model. The second section of this chapter analyses the dynamic effects of the China-New Zealand FTA and the China-Australia FTA. 
The dynamic effects include competitive effects of trade in goods, in services and investment creation. Chapter 4 shows the non-traditional gains of the China-New Zealand FTA and the China-Australia FTA again over two aspects, the RTAs strategies of China, New Zealand and Australia and the insurance effect under the world economic crisis. The last chapter is conclusion which summarises the results and relates these findings back to the existing literature.

\subsection{Literature Review}

After several decades of economic integration in many parts of the world there has been an explosion of detailed theoretical accounts of regional economic integration. These theories roughly sit in two camps: those that study traditional gains; and those that study non-traditional gains as well as the traditional gains. Most studies on the traditional gains of RTAs are constructed based on Viner's or Balassa's core theories. The study of non-traditional gains of RTAs is a relatively new theoretical perspective. The work of Fernández and Portes is representative of this new theoretical field. This research utilises both classic theories to evaluate the economic impacts of the north-south FTAs and the newer non-traditional gains theories. The following three sections of this literature review summarise and critique the classic theories, the non-traditional theories and explain the methodology of this research.

\subsubsection{Economic Research and the Theory of Traditional Gains}

Viner (1950) first used the concepts Trade-Creating Effect and Trade-Diverting Effect in his 1950 book "The Customs Union Issue". He uses these two concepts to measure the 
benefits and damages caused by a customs union. Viner found that trade creation benefits (from a customs union) derive from free trade. Free trade is made possible by eliminating trade barriers between members of a customs union. On the contrary he also found that the damage of trade diversion is induced by protection in a customs union to the external trading world. Viner argues that a customs union should be operated by members with less complementarity or with greater degree of rivalry and points out that "...Customs unions, actual or projected, however, appear invariably to include only contiguous territory" (Viner 1950, 60). That means a customs union should also be operated between those geographically close members.

Krugman (1991) disagreed with Viner on the point of geographic location between the members of customs unions. He believes that customs unions should not be established between partners in the same contiguous territory. He affirms that most members of RTAs suffer from decreased welfare caused by the trade-diverting effect precisely because of their contiguous territory. In essence, Krugman argues that before establishing the regional trade agreements members of the customs union already have a certain degree of trade with each other. In this case, the small members would lose the tariff revenue and have to assume the damage of re-allocation after the agreements are signed.

Corden (1972) supports Viner's argument. He explains that the concepts of trade creation and trade diversion are relevant and adds two new concepts, the Cost Reduction Effect and the Trade-Suppression Effect using a three-country model. Corden argues that there is a cost reduction created by an economy of scale. Trade suppression refers to the idea that "...when the union is formed ...imports from the external world may cease because they 
are replaced by domestic production." (Corden 1972, 473) All four effects (the trade creation effect, the trade diversion effect, the cost reduction effect and the trade suppression effect) have a production and a consumption component and all the gains and losses from them are borne by consumers in the union.

Robson (1980) uses Viner's and Corden's classic theories about customs unions to develop a new theory about free trade agreements. He compares the economic effects between FTAs and customs unions by using a comparative-static analysis method and by constructing a three-country model. Robson's research showed that FTAs are preferable to customs unions because of their effects on static allocative efficiency. Allocative efficiency means overall economic efficiency ${ }^{3}$ in a society and static can be explained that the situation does not change in-period. Robson's finding has been used as a persuasive argument for the FTA becoming a more important form of regional integration in the last two decades. ${ }^{4}$

Balassa (1961) argues that the static effect that Viner discovered is just a part of the overall regional economic integration effect. He argues that the dynamic effects of regional economic integration include economic growth, economies of scale and external economies and so on. He discusses the advantages and the risks of large-scale international production from the perspective of industries. His theory offers a whole new perspective to

\footnotetext{
${ }^{3}$ Economic efficiency is a state where nothing can be adjusted so that someone is made better off without someone else being made worse off, and is formally called Pareto Efficiency.

${ }^{4}$ It should be noted that the limitation of FTAs in terms of regional integration are their few vacancies for financial and currency integration.
} 
survey the benefits of regional integration. Balassa's explanation becomes the foundational theory of dynamic effects.

Based on these orthodox theories, many Chinese scholars have constructed models to analyse the traditional gains for China from RTAs. CHEN and YIN (2008) use the Vector Error Correction (VEC) model to predict the dynamic economic impacts on Chinese industry production, trade and investment. Their analysis shows that after signing FTA agreements, China will suffer decreases in industry production and employment in the short term, but in the long run increase and go beyond the original level. Their findings showed that Chinese exports will expand continually but imports will expand first then shrink in the long term. Moreover, they argued that FTAs would have little impact on investment. They did however show that a negative effect of the FTA strategy for China is that wage levels will continually decrease from the beginning of the agreements.

There are also many studies that analyse the effects of the China-New Zealand FTA and the Australia-China FTA. MAI, ADAMS, FAN, LI and ZHENG (2005) construct a Computable General Equilibrium (CGE) Model to analyse the potential benefits of a China-Australia FTA. They assert that the FTA will generally have positive effects for both countries through increases in real GDP, partly via productivity improvements and welfare enhancement. Another perspective is given by YANG, HUANG and QIU (2005). They created the Global Trade Analysis Project (GTAP) to model the China-Australia FTA. Their analysis shows that the gains for China come from labour-intensive industries but that the conditions of Chinese agriculture would deteriorate due to increased competition. 
They assert that Australia would benefit far more from the FTA than China. Notably, Australia's GDP would increase by $0.21 \%$ induced by their advantages in agriculture and industry sectors. ${ }^{5}$

This conclusion is supported by the findings of ZHOU, WU, HU and CUI (2006). They also predict that New Zealand will suffer a trade diversion effect because of the proposed China-Australia FTA. However, the authors seem to have failed to follow carefully the negotiation of China-New Zealand FTA. It is unlikely that a trade diversion effect will occur among China, New Zealand and Australia because of the "global free trade" mode constructed by the three FTAs (Australia-New Zealand Closer Economic Relations, China-New Zealand FTA and China-Australia FTA). The "global free trade" mode guarantees neither China, New Zealand nor Australia will suffer trade discrimination in the scope of the FTAs.

LI, SHAO and CHEN (2008) construct the GTAP model and discuss the influences of China-New Zealand FTA. They contend that China would suffer negative impacts on GDP and welfare but New Zealand would get positive impact for GDP and welfare. Specifically the terms of trade would deteriorate by $0.03 \%$ for China and for New Zealand it would be improved by $0.3 \%$.

All these studies have similar findings showing the GDP and welfare for Australia and New Zealand improving due to the FTAs but an uncertain situation for China or possibly

\footnotetext{
${ }^{5}$ The dedication rate of the agriculture sector to Australia's GDP growth is twice that of the industry sector.
} 
economic trade conditions even worse than before. In both the New Zealand and proposed Australian FTAs, China's concessions are far greater than Australia's and New Zealand's. These conclusions show some positive aspects to the FTAs and provide some evidence to support their findings. However, the newest data for GTAP is from 2001. Out of date data affects the accuracy of the conclusions and does not provide a clear picture of the contemporary effects that can be expected from the creation of the 'global free trade' mode. Furthermore, the GTAP is a static model and it can not reflect the influence of policy changing on regional economic integration. In addition all analyses above about the China-New Zealand FTA or the China-Australia FTA neglect the existence of dynamic effects and non-traditional gains. This research seeks to address these issues by utilising up to date data and models that incorporate both traditional and non-traditional gains in the analysis of the FTAs effect. The next section overviews theory and research of non-traditional gains.

\subsubsection{Economic Research and the Theory of Non-Traditional Gains}

Fernández and Portes (1998) argue that the motivation for smaller or economically weaker countries making the bulk of concessions to join in RTAs with larger countries is non-traditional gains. They contend that the non-traditional gains help solve the time-inconsistency problem ${ }^{6}$ and that free trade agreements provide a positive signal for the future relationship between governments. Non-traditional gains also include insurance against possible future events and represent a form of bargaining power with respect to

\footnotetext{
${ }^{6}$ Time inconsistency problem means the government changes its policy under the given situation without a commitment mechanism. However, the changed policy makes the overall welfare worse off because the policy and its work time is inconsistent.
} 
third parties. Fernández and Portes (1998) argue that these effects happen after RTAs are signed because retaliatory punishment and reputation loss are more efficient in RTAs than in the WTO. Besides, the cost of exiting from RTAs is large enough to outweigh the gains from simply abrogating the agreements. For the reasons above the members tend to comply with the commitments they made in the RTAs. Another reason Fernández and Portes (1998) give for small developing countries to form their own regional block is "...fearing more protectionist responses from 'fortress Europe' and seeing a reduction in the number of potential alternative trade partners". (Fernández and Portes 1998, 211)

Another point of view is provided by Hoekman (2005). He discusses the reasons for many poor developing countries pursuing preferential trade agreements (PTAs) with powerful developed countries even when they are confronting potential loss of wealth. Hoekman argues that this is not based on mercantilist ideas or deep integration of markets but is motivated by the desire to achieve economic self-development. Developing countries already have good access to the major markets of developed countries but at the same time they have high tariffs or other trade barriers to protect their small developing domestic markets. This situation suggests they will not benefit greatly from a traditional trade agreement. However, because they treat the PTAs with major markets as "a mechanism to lock in trade reforms, a focal point for future reforms and a device to help overcome resistance by vested interests" (Hoekman 2005, 26) they are motivated to be involved with PTAs even when the traditional economic gains are most likely negative. Thus, Hoekman argues that an improving investment climate and a developing trade capacity are the main objectives for poor developing countries to sign PTAs with developed partners. In order to 
achieve these objectives they are compelled to accept some sensitive requests from the developed economies, for example government reform monitoring, policy transparency and opening of the financial market and so on.

The opinions above are echoed by LI (2002). He agrees that developing countries use north-south RTAs to promote reforms, attract foreign investment and narrow the income gap between the RTA members. He also reveals that great changes have taken place not only in incentives and the forms of the RTAs but also in the effects these RTAs have on regional economic integration. Specifically, LI (2002) argues that for developing countries dynamic effects of the RTAs attract more attention than static effects. Moreover, in the forms of the RTAs north-south RTAs are preferable than north-north RTAs or south-south RTAs for both the developed and developing economies. Furthermore the competition among the great powers such as the US or Japan becomes the competition among the RTAs such as NAFTA and EU.

The general assumption in orthodox theories about small or developing countries is that these countries have small domestic markets and are economically weak. On the contrary China is a big developing country with a huge domestic market and the third highest ranking of GDP value of the world in year 2008 (CIA 2008). New Zealand is relatively small developed country with limited population and domestic market. Even though Australia is an important advanced economy in the Asia-Pacific region, it is not as big as China in terms of the scale and the value of the economy. New Zealand's GDP value was $54^{\text {th }}$ and Australia's $14^{\text {th }}$ highest in the world in 2008 (CIA 2008). This means the 
traditional assumptions about the north and the south countries do not fit the reality of the north south agreements between New Zealand, Australia and China. This also means it is highly likely the conclusions of the traditional theories are also incorrect.

Although after the establishment of the WTO in 1995 world trade was initially more prosperous for several years, multilateral trade has been gradually being replaced by regional or bilateral trade. This is because even though the international trade rules became clearer and the tariffs of the WTO members were reduced a lot, the implementation of multilateral trade has been hindered by stalls in negotiations during the Doha Round in 2001. Considering that economic connections and dependence is growing by the day, signing stable regional integration agreements is a significant tool for governments to avoid trade barriers or retaliation by partners under some circumstances.

In summary, even though in many circumstances the traditional gains of joining an RTA are negative for a developing country the non-traditional gains can be significant leading the developing country to partake. Moreover, traditional analysis of the gains of RTAs has focused on a limited definition of north and south countries. China, whilst remaining a developing country, is a large economy of scale in comparison to the north countries New Zealand and Australia. For these reasons the following research seeks to gain a better understanding of both the traditional gains and non-traditional gains of RTAs between cases that do not easily fit into existing traditional theories of why countries enter into FTAs. 


\subsection{Methodology, Contributions and Limitations of this Research}

The following section outlines the methodology, contributions of this research to the literature and the limitations of this research. The methodology of the research will be discussed first. For the convenience of analysis this research assumed that the China-Australia FTA has already entered into force as the China-New Zealand FTA already has. The previously mentioned discussion of the static effect of the north-south FTA relied heavily on theories of economic gain. This research relies on an empirical method to evaluate the dynamic economic effects and non-traditional gains of the China-New Zealand FTA and the China-Australia FTA. The conclusion will discuss the implications of the findings of this research in relation to these theories and conclude as to the efficacy of their approach and provide a possibility for new theoretical innovation in light of the findings.

Traditional gains will be measured by the static effect and the dynamic effect. The static effect of the north-south FTA is measured by the balance of trade creation and trade diversion. The dynamic effects of the China-New Zealand FTA and the China-Australia FTA will include the competitive effects on trade in goods, in services and investment creation. Then the non-traditional gains will be examined over three aspects: the Hub \& Spoke (H\&S) effect, the RTAs strategies of China, New Zealand and Australia and the insurance effect under the economic crisis. 
The static effect of trade-creation and trade-diversion was illustrated by Robson's (1980) three-country model which will be modified a little to make it appropriate to the north-south model. While the dynamic effects of an FTA are plentiful this research can not fully capture all of them and is therefore limited in scope. This analysis will utilise the most obvious and important one- the Competitive Effect, for the reason that it is generally considered to be the greatest dynamic effect and is the easiest to measure. The competitive effect will focus on the competition among China, New Zealand and Australia after the tariffs are eliminated when the China-New Zealand FTA and the China-Australia FTA enter into force. The competitive effects of trade in goods and in services will be calculated using the Revealed Comparative Advantage (RCA) Index (Balassa 1965) and the Trade Competitive Power (TC) Index (Peterson and Barras 1987) respectively. The competitiveness of China, New Zealand and Australia will be quantified by the RCA and the TC indexes over different industries.

There are four steps involved in the RCA index calculation. Firstly, collect trade data in all kinds of industries (export and import data) between China, New Zealand and Australia in the five years between 2003 and 2007. Secondly, find the products in competition on the markets of China, New Zealand and Australia separately. For example, the products in competition on the market of China can be found in the following way: (1) Comparing every year's top 20 import products from New Zealand and finding the overlapped ones between 2003 and 2007. These products will be New Zealand's main exports to China and also the products in competition with China. (2) Finding the products in competition between Australia and China in the same way. (3) Comparing the main imports from New 
Zealand and Australia. The overlapping products will be the products in competition between New Zealand and Australia on China's market. The way to find competing products on New Zealand and Australia markets is exactly the same three steps. Thirdly, calculate the RCA indexes of the competing products and combine them with tariff elimination in the FTAs. Finally, estimate the competitive effects and the economic impacts on different industries.

There are three steps involved in measuring the competition effect of trade in services in the TC indexes. Firstly, collect data of trade in services of China, New Zealand and Australia during 2005 and 2006 (the newest available data from United Nations Conference on Trade and Development for all the three countries). Second, calculate the TC indexes of China, New Zealand and Australia by different categories of the services industry. Finally, estimate the services competition among China, New Zealand and Australia through the quantified competitiveness of the three countries.

Turning to the non-traditional gains this research will combine the H\&S theory ${ }^{7}$ with the RTAs strategies of China, New Zealand and Australia. It is hypothesised that this part of the analysis will provide an explanation of why the China-New Zealand FTA and the China-Australia FTA were significant especially under the global economic crisis. The hub and spoke theory explains the situation of international regional integration and analyses the different gains for the hub country and the spoke country. The method for analysing the

\footnotetext{
${ }^{7}$ Hub \& Spoke Theory was created by Wonnacott 1996.
} 
RTA strategies of China, New Zealand and Australia is based on the signing of their regional agreements. This research will dig further for their motivations for signing RTAs.

The contribution to existing literature of this research is the combined analyses of economic impacts of the China-New Zealand FTA and the China-Australia FTA. This research focuses on the dynamic effects and the non-traditional gains and hypothesises that this will be the main source of benefits for China. This contributes to the literature because these benefits have for most been neglected by most scholars studying north-south RTAs and in particular the 'global free trade' mode of New Zealand, Australia and China. Furthermore, this research will quantify the competitiveness of China, New Zealand and Australia on trade in goods and in services using the RCA and TC indexes separately. One limitation of this approach is that conclusions relating to the dynamic effects will be based on indexes which are calculated using trade data in the past. As a result, the conclusions may be affected by some temporary trade policies or special events and distort the realities of competition. This is also a limitation of this research. The next chapter provides an introduction to the China-New Zealand FTA and the China-Australia FTA. 


\section{The China-New Zealand FTA and the China-Australia FTA}

Both the proposed China-Australia FTA and the recently signed China-New Zealand-China FTA are significant RTAs for China. They represent China's entrance into North-South RTAs and signal a new regional economic strategy for both New Zealand and Australia. This chapter will overview the China-New Zealand FTA under the sections, trade in goods, trade in services and investment before providing an introduction to the proposed China-Australia FTA. The chapter will conclude by discussing the status quo trade situation amongst China, New Zealand and Australia.

\subsection{The China-New Zealand FTA}

The Free Trade Agreement between China and New Zealand was signed on 7th April 2008 after 15 rounds of negotiation over 3 years and entered into force on 1st October 2008. This is the first comprehensive trade agreement that China has signed and also the first trade agreement between China and a developed economy. The Free Trade Agreement between the Government of the People's Republic of China and the Government of New Zealand has 18 chapters which cover nearly all the economic sectors of China (trade in goods, in services, investment, labour and cooperation etc.). ${ }^{8}$ This treaty aims to liberalise and facilitate trade in goods and services, to encourage mutual investments, to improve

\footnotetext{
${ }^{8}$ The 18 chapters are: Initial provisions, General definitions, Trade in goods

Rules of origin and operational procedures, Customs procedures and cooperation Trade remedies, Sanitary and phytosanitary measures, Technical barriers to trade Trade in services, Movement of natural persons, Investment, Intellectual property Transparency, Cooperation, Administrative and institutional provisions Dispute settlement, Exceptions and Final provisions.
} 
business environment and to promote cooperation between China and New Zealand in a broad range of economic areas. (NZMFAT 2008)

\subsubsection{Trade in Goods}

According to the agreement, New Zealand will remove all the tariffs on China exports before $1^{\text {st }}$ January $2016.63 .6 \%$ of them were removed immediately when the FTA took effect. China will eliminate the tariffs on $96 \%$ of New Zealand exports before $1^{\text {st }}$ January 2019 and $24.3 \%$ of them went into effect on $1^{\text {st }}$ October 2008 . Table 1 outlines the specific tariff removal steps of the China-New Zealand FTA. 
TABle 1 TARIfF Removal Steps

\begin{tabular}{|c|c|c|c|c|}
\hline \multirow[b]{2}{*}{$\begin{array}{l}\text { Date for } \\
\text { Tariff } \\
\text { elimination }\end{array}$} & \multicolumn{2}{|c|}{ New Zealand Exports to China } & \multicolumn{2}{|c|}{ New Zealand Imports from China } \\
\hline & $\begin{array}{l}\% \text { of total } \\
\text { NZ exports } \\
\text { to China }\end{array}$ & Key products & $\begin{array}{l}\text { \% of total NZ } \\
\text { imports from } \\
\text { China }\end{array}$ & Key products \\
\hline $\begin{array}{lr}1 & \text { October } \\
2008 \text { (date of } \\
\text { entry into } \\
\text { force) }\end{array}$ & $35.30 \%$ & $\begin{array}{l}\text { Certain types of } \\
\text { fibreboard, fish meat, } \\
\text { scrap metal (copper and } \\
\text { aluminium), coking coal } \\
\text { and iron slag }\end{array}$ & $38.60 \%$ & $\begin{array}{l}37 \% \text { of trade is } \\
\text { already duty free }\end{array}$ \\
\hline 1 January 2009 & $6.00 \%$ & $\begin{array}{l}\text { Around } 75 \% \text { of current } \\
\text { wool exports (with the } \\
\text { balance of current exports } \\
\text { becoming duty-free over } \\
8 \text { years) }\end{array}$ & & \\
\hline $\begin{array}{l}1 \quad \text { January } \\
2012 / 2013\end{array}$ & $31.20 \%$ & $\begin{array}{l}\text { Infant milk formula, } \\
\text { casein, yoghurt, frozen } \\
\text { fish, frozen fish fillets, } \\
\text { methanol, animal fats \& } \\
\text { oils, apples and wine }\end{array}$ & $35.30 \%$ & $\begin{array}{l}\text { Steel, white ware } \\
\text { plastics, furniture, } \\
\text { tyres, pens }\end{array}$ \\
\hline 1 January 2014 & & & $4.20 \%$ & $\begin{array}{lr}\text { Textiles, } & \text { some } \\
\text { clothing } & \text { and } \\
\text { footwear } & \text { and } \\
\text { carpets } & \end{array}$ \\
\hline 1 January 2016 & $4.60 \%$ & $\begin{array}{l}\text { Edible offal, oranges, } \\
\text { orange juice, milking } \\
\text { machines Sheep \& beef } \\
\text { meat, kiwifruit, } \\
\text { sheepskins }\end{array}$ & $21.50 \%$ & $\begin{array}{l}\text { Clothing } \\
\text { footwear }\end{array}$ \\
\hline 1 January 2017 & $2.50 \%$ & $\begin{array}{l}\text { Butter, cheese and liquid } \\
\text { milk }\end{array}$ & & \\
\hline 1 January 2019 & $15.20 \%$ & $\begin{array}{l}\text { Whole and skim milk } \\
\text { powders }\end{array}$ & & \\
\hline $\begin{array}{l}\text { Country-Specif } \\
\text { ic Tariff Quota } \\
\text { for wool }\end{array}$ & $8.10 \%$ & Wool and wool tops & & \\
\hline $\begin{array}{l}\text { No tariff } \\
\text { reductions } \\
\text { under the FTA. }\end{array}$ & $4.00 \%$ & $\begin{array}{l}\text { Certain paper products } \\
\text { and certain processed } \\
\text { wood products. Wheat, } \\
\text { sugar, rice }\end{array}$ & & \\
\hline
\end{tabular}

Source: New Zealand Ministry of Foreign Affairs \& Trade (NZMFAT), December 2008. 


\subsubsection{Trade in Services}

According to the agreement, China and New Zealand will reduce the barriers to trade in services and open service markets to each other. Both countries have made commitments in the FTA that expanded on their respective commitments in the WTO General Agreement on Trade in Services (GATS). It should be noted that the service trade barriers refer to different rules or requirements for foreign companies compared to local companies that are designed to give local companies a competitive advantage. The barriers also refer to requirements for foreign companies to employ a certain percentage of locals or to enter into a joint venture with a local company (NZMFAT 2008). Specifically, the China-New Zealand FTA includes a reciprocal Most Favoured Nation (MFN) provision covering the services in the following sectors: construction services (construction work for buildings, assembly and erection of prefabricated constructions, installation work and building completion and finishing work); environmental services; services incidental to agriculture and forestry; engineering services; integrated engineering services; computer and related services; and tourism services.

The MFN provision means that exporters of these services will automatically receive the benefit of commitments that each country makes in future free trade agreements that are more liberal than those in the China-New Zealand FTA. This will help to ensure that each country's competitive position for the supply of services in the other country's market is not eroded. The obligation of "most favoured nation" does not apply to treatment granted 
by either country to third countries under any previous free trade agreement (NZMFAT 2008).

\subsubsection{Investment}

The China-New Zealand FTA contains measures to encourage and promote the flow of investment between New Zealand and China. The parties also work together to increase the security of investments in each country (NZMFAT 2008). Both countries have agreed to treat investors and investments of the other country at least as well as they treat their own investors ("national treatment") on investment administration, management, interest and disposition. Both countries have also agreed to give Most Favoured Nation treatment to investment and investors of the other country, except in respect of fisheries and maritime matters. Otherwise the obligations on trade in services and investment do not apply in respect of subsidies or government procurement.

A Joint Study Report on a Free Trade Agreement between China and New Zealand modelled the implementation of China-New Zealand FTA with global general equilibrium model and analyzed the possible effects on production (real GDP) and welfare (real consumption). The study shows that if the China- New Zealand FTA was to commence from 2007, the static gains would induce New Zealand's real GDP and real consumption by 0.15 and 0.35 percent higher than it would be in the absence of a China- New Zealand FTA over a ten year period. On the other hand China's real GDP and real consumption would only rise by 0.001 and 0.006 percent respectively under similar conditions. Instead if the gains from China-New Zealand FTA including benefits derived from static and 
dynamic effects, in a decade, the numbers for real GDP and real consumption would be, respectively, 0.25 and 0.55 percent higher for New Zealand and 0.07 and 0.17 percent higher for China $(2004,78)$. The joint study on the China-New Zealand FTA shows that the benefits derived from static effect for China are insignificant for China.

Overall, the New Zealand China FTA is a significant RTA that covers trade in goods, services, investment and other areas between the two countries. It is a significant step for both China and New Zealand that is predicted to benefit both economies, though traditional analysis shows those benefits are better for New Zealand than China, and enhance the level of trade and business between them. The proposed China-Australia FTA is also a significant RTA that should encompass many of the aspects of the China-New Zealand FTA but that also has some significant differences leading to prolonged negotiation.

\subsection{The China-Australia FTA}

Australia and China agreed to commence a negotiation of a Free Trade Agreement after Australia's recognition of China's economy market status on $18^{\text {th }}$ April 2005. ${ }^{9}$ This negotiation has lasted for three years and the $13^{\text {th }}$ round was held in Beijing in December 2008. So far both sides have made great progress on the framework for the FTA and the discussions includes trade in goods, in services, investment, rules of origin, customs procedures, sanitary and phytosanitary issues. They have also discussed technical barriers to trade, intellectual property and government procurement. However, Chinese market access for agriculture products and Australia's sensitivity about further tariff liberalisation

\footnotetext{
${ }^{9}$ New Zealand recognised China’s market economy status in April 2004.
} 
of certain manufactured products are the main reasons for the slow progress of this negotiation.

The Australia-China Free Trade Agreement Joint Feasibility Study anticipated the aggregate economic impact from the FTA. If the FTA was fully implemented in 2006, the model suggested that "...Tariff and tariff rate quota liberalisation was estimated to increase Australia's and China's average annual real GDP growth rate by 0.012 and 0.006 percentage points respectively." $(2005,127)$ However, the combined effect of liberalising services and investment was estimated to increase the average annual real GDP growth rate for both Australia and China by 0.039 and 0.042 percentage points respectively. The joint study on China-Australia FTA indicates that the gains only acquired from merchandise trade are insignificant. The situation improves when the dynamic effect or the services trade gains are considered. Therefore it is essential for China to build comprehensive north-south FTAs including services and investment liberalisation to capitalise on the growing trade between New Zealand, China and Australia and to ensure Chinese companies have a strong market position in the growing regional economy.

\subsection{The trade status quo among China, New Zealand and Australia}

In 2007 the bilateral trade in goods between China and New Zealand was 5.31 billion US dollars, an increase of $25.5 \%$ from 2006. In the same period, New Zealand's trade in goods achieved an average growth of $18.6 \%$ which is lower than the trade growth rate between New Zealand and China. China is the $3^{\text {rd }}$ trade partner, $4^{\text {th }}$ export market and $2^{\text {nd }}$ source of imports for New Zealand (MOFCOM 2008). In 2007 bilateral trade in goods between 
China and Australia was 44.48 billion US dollars with a growth rate of $28.5 \%$ from 2006 . In the same period, Australia's trade made an average growth of $16.8 \%$. China is Australia's $1^{\text {st }}$ trade partner, $2^{\text {nd }}$ export market and $1^{\text {st }}$ source of imports (MOFCOM 2008). Undoubtedly, China is an important trade partner and a huge destination of exports for both New Zealand and Australia.

Table 2 Export And Import among China, New Zealand and Australia in 2007 Unit: billion US Dollars

\begin{tabular}{l|lll|llll|lll|lll|l}
\hline \multicolumn{3}{c|}{ China } & \multicolumn{9}{c|}{ New Zealand } & \multicolumn{1}{c|}{ Total } \\
\hline & Export & Growth & Proportion & Export & Growth & Proportion & Export & Growth & Proportion & Export & Proportion \\
\hline China & $/$ & $/$ & $/$ & 3.87 & $28.5 \%$ & $0.32 \%$ & 24.46 & $27.2 \%$ & $2.01 \%$ & 28.33 & $2.33 \%$ \\
NZ & 1.44 & $18.3 \%$ & $5.3 \%$ & $/$ & $/$ & $/$ & 5.93 & $29.2 \%$ & $22 \%$ & 7.37 & $27.3 \%$ \\
Australia & 20.01 & $30.1 \%$ & $14.2 \%$ & 6.06 & $20.2 \%$ & $5.6 \%$ & $/$ & $/$ & $/$ & 26.07 & $19.8 \%$ \\
\hline
\end{tabular}

Data Source: Calculated based on trade data from Country Trade Report, China MOFCOM.

Table 2 shows that export from New Zealand to China accounted for 5.3\% of its total export in the year 2007 and the proportion for Australia was 14.2\%. This again points out the fact that China is a large export market for both Australia and New Zealand. On contrary, export to New Zealand and Australia only accounted for $2.33 \%$ of China's total export in 2007. The small percentage of China's total exports means that New Zealand and Australia are not very important export markets for China. Data also showed that imports from New Zealand and Australia only accounted for $2.24 \%$ of China's total imports in 2007. However, it is too simplistic to merely conclude that Australia and New Zealand are not an important import source of imports for China. Beyond the statistics we should also look at the types of products China imports from New Zealand and Australia. Imports from New Zealand to China mainly consist of live animals, animal products, wool and wood products. Imports from Australia mainly consist of minerals, wool and non-ferrous metals. 
All these resource products are very important for the development of China. Furthermore, to some extent, the prices and supply of these resource products are a key element of the cost control and the long-term plan for China's development.

According to China Custom Statistics, iron ore is the $4^{\text {th }}$ import product of China and Australia is China's biggest iron ore import resource. Considering the quality of iron ore, the location of iron ore supply countries and relative transportation expenses the status of Australia in the iron ore area means that there is no alternative for China. On the other hand the exports from China to Australia are mainly textiles and low-technology manufactures which could be substituted easily by other suppliers. This asymmetric relationship between demand the supply results in a unilateral dependence and trade sensitivity of China to Australia. Thus signing FTAs with New Zealand and Australia plays a key role in reducing the cost of development and searching for stable resource providers for China. On the other hand, the FTAs bring New Zealand and Australia the biggest and fastest growing goods and services market in the world with no tariff or trade barriers. The next chapter will measure the traditional gains of these FTAs. 


\section{Traditional Gains of North-South FTAs}

This chapter will measure the traditional gains for China, New Zealand and Australia from the FTAs. The chapter is structured into two main sections, the static effects of the North-South FTAs and the dynamic effects of the FTAs. After measuring the static effects the focus of the chapter will be on the competitive effect on trade in goods, trade in services and investment creation. The chapter will conclude by summarising these traditional gains.

\subsection{Static Effect of the North-South FTAs}

The core theory on regional trade integration comes from Viner's two definitions, the Trade Creating Effect and the Trade Diverting Effect. These are the foundation of the static effect which essentially is a measurement for benefit allocation between the members of a customs union. Robson (1980) expanded the theory to apply to free trade agreements. The static effect in this research used Robson's three-country model and made some minor alterations to depict the benefit distribution in the north-south FTA.

The Trade Creating Effect is defined as: "There will be commodities, however, which one of the members of the customs union will now newly import from the other but which it formerly did not import at all because the price of the protected domestic product was lower than the price at any foreign source plus the duty." (Viner 1950, 43)

The trade creation effect derives from free trade after the removal of trade barriers. Such a shift has two aspects, the product effect and the consumption effect. The production effect 
involves the removal of tariffs creating new imports from the member country with lower cost. The new import substitutes identical commodities produced by the home country at a higher cost. From the perspective of the whole free trade area the cost of production is lowered. The consumption effect argues that consumers in the home country are satisfied with lower cost goods from the member country which induces the benefit of consumers' surplus.

The Trade Diverting Effect is defined as: "There will be other commodities which one of the members of the customs union will now newly import from the other whereas before the customs union it imported them from a third country. Because that was the cheapest possible source of supply even after payment of duty." (Viner 1950, 43) The trade diversion effect derives from trade protection against the outside world by the regional integration area. Such a shift can also be divided into two aspects, the cost inflation and decreased consumer welfare. Cost inflation describes the original lower cost import from the outside world being replaced by a higher cost import from the member of the FTA, which induces increased cost of production. Decreased consumer welfare describes the consumption of the lower cost goods from the outside world being replaced by consuming higher cost goods from the member. This substitution results in a loss of consumer surplus.

Where the trade creating effect is predominant, at least one member of the FTA can benefit. Where the trade diverting effect is predominant, there are at least two parties injured. One is a member of the customs union and the other is the original trade partner from the outside world. (Viner 1950, 44) When the trade creating effect weighs more than trade 
diverting effect, the static effect in this customs union is positive, and vice versa. This theory is also appropriate for free trade areas, but two key features are different from the customs union: Firstly, the members of the FTA keep their own tariff systems to the outside world; Secondly, the rules of origin, the preferential terms are only applied to the commodities originally produced in the free trade area. The rules of origin are intended to prevent trade deflection, that is "...a redirection of imports through the country with the lowest tariff for the purpose of exploiting the tariff differential." (Robson 1987, 23)

\subsubsection{Assumptions of the modelling}

Assumptions: there are three countries in the world, one is an efficient country in the North, another is a non-efficient country in the South with a large market and the rest of the world is the third country. The two countries from the North and the South form a free trade area, which means no tariff or trade barriers between the two countries and in this area competition is perfect. However, both countries retain their tariffs on the third country; the country in the North with low tariffs and the country in the South with high tariffs.

\subsubsection{From the perspective of a single-country (Figure 1)}

Before the FTA is established, both countries produce one kind of identical commodity of their own with different tariffs for this commodity. The country in the South has a prohibitive high tax $\mathrm{WT}_{\mathrm{S}}$, and excluding all imports, the supply curve is $\mathrm{S}_{\mathrm{S}}$ and the supply is OL. Meanwhile the country in the North has a much lower tariff $\mathrm{WT}_{\mathrm{N}}$. After the FTA is brought into force, the country in the South's demand curve stays the same, but the supply curve becomes $\mathrm{S}_{\mathrm{N}+\mathrm{S}}$, which is the sum of the North and South's supply curves horizontally. 
Although OW is the world's supply price, goods from the third country cannot be imported from the country in the North to the Southern market because of the rules of origin. Consequently the prices for the commodity are different in and outside the area. The price in the country in the South is between $\mathrm{OT}_{\mathrm{N}}$ and $\mathrm{OT}_{\mathrm{S}}$ as long as the free trade area is still a net importer. From the country in the South's point of view, the efficient supply curve is $\mathrm{T}_{\mathrm{N}} \mathrm{BFGK}$ including commodities produced both in and outside the area. The country in the North's supply to the Southern market is decided by the price in the country in the South. Furthermore, the price in the country in the South is decided by the demand curve of the country in the South. There are two possible conditions depending on the two kinds of demand curves $\mathrm{D}_{\mathrm{S}}$ and $\mathrm{D}_{\mathrm{S}}$ '.

\subsubsection{The first condition}

Figure 1 The static effects of a FTA on a single country

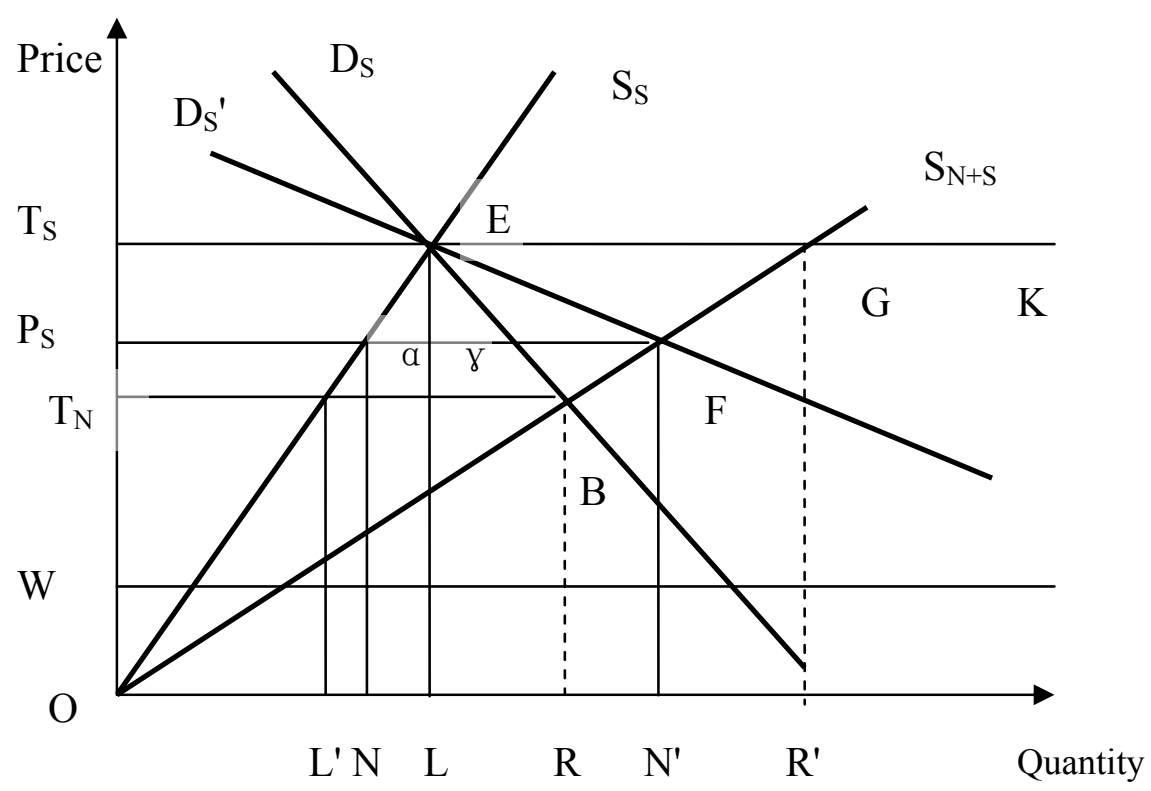

Adapted from Robson 1987, 24. 
In the first condition, the demand curve of the country in the South is $\mathrm{D}_{\mathrm{S}}$. The price in the country in the South drops to $\mathrm{OT}_{\mathrm{N}}$ which is the single equilibrium price in the free trade area. The country in the North provides all their production (L'R) to the country in the South at the price $\mathrm{OT}_{\mathrm{N}}$ and imports the same quantity from the outside world for their own consumption. At the same time, the production of the country in the South decreases to OL'. In that case, parts of the high cost domestic production ( $\left.\mathrm{L}^{\prime} \mathrm{L}\right)$ is replaced by the low cost production of the north, which is the production effect and is represented by $\alpha$. Meanwhile $\gamma$ represents the positive consumption effect which is caused by the lower price. Together the two effects constitute the trade creation effect in the north-south FTA.

\subsubsection{The second condition}

In the second condition, the demand curve of the country in the South is more elastic $\left(\mathrm{D}_{\mathrm{S}}{ }^{\prime}\right)$. $D_{S}$ ' has an intersection $F$ with the efficient supply curve $T_{N} B F G K$. The intersection $F$ decides the price $\left(\mathrm{P}_{\mathrm{S}}\right)$ in the country in the South which is between $\mathrm{T}_{\mathrm{S}}$ and $\mathrm{T}_{\mathrm{N}}$. At this price, the production in the country in the South itself is ON. The country in the North provides the Southern market $\mathrm{NN}^{\prime}$ and the insufficiency of its own is satisfied by imports from the outside world. Similar to the first condition, the efficient production substitutes the inefficient one. The substitution causes production effects and consumption effects which are the bases of the trade creation effect (the triangle area constituted by $\mathrm{D}_{\mathrm{S}}$, $\mathrm{S}_{\mathrm{S}}$ and $\mathrm{P}_{\mathrm{S}}$ ).

\subsubsection{From the perspective of two countries}

Before the FTA is established, the country in the North has a prohibitive tax $\mathrm{WT}_{\mathrm{N}}$ for the commodity. However, the prohibitive tax is not as high as the tax in the country in the 
South because the country in the North is an efficient producer. At the beginning, the country in the North is self-sufficient on commodities and the equilibrium quantity is OM.

\subsubsection{The first condition (Figure 2)}

Before the FTA enters into force, the production of the country in the South is OL and the consumption is ON. The balance LN is satisfied by the import from the outside world at the lowest price. There is a duty revenue $\mathrm{LN} \times \mathrm{WT}_{\mathrm{S}}$ for the country in the South. It is assumed that the demand terms of the countries in the North and South are similar. The supply curve of the country in the North is elastic and competitive. As a result the quantity beyond OL" is produced at the price over OW. In that case, the countries in the North and South establish an FTA, which creates a single equilibrium price. The equilibrium price should equal the previous lower price of the members.

As shown in Figure 2, the price in the area drops to TN, and the combined supply of the countries in the North and South $(\mathrm{OM}+\mathrm{OL})$ is obviously lesser than the combined demand of this area $\left(\mathrm{OM}+\mathrm{ON}^{\prime}\right)$. Therefore in an FTA that excludes the lowest world price $\mathrm{OW}$, the country in the North satisfies its Southern partner's demand with L'N' (=L"M) at the price TN, leaving its own market OL". On the other hand the country in the North imports L"M to fill up the balance from the outside world at the lowest price OW. 
The production effect $\alpha$ and consumption effect $\gamma$ constitute the trade creation effect. It is bigger than the trade diversion effect $\beta$ which is conduced by the replacement of the higher

Figure 2 The Static Effect of a FTA on Two Countries (a)

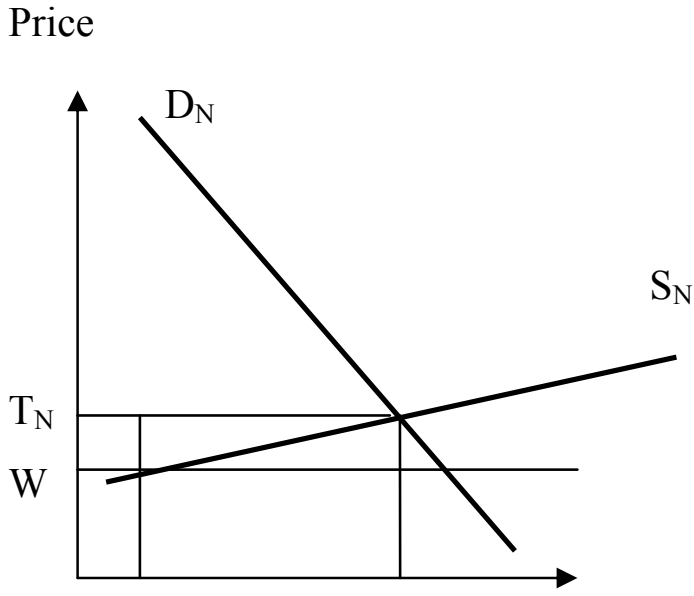

$\mathrm{O} \quad \mathrm{L} "$

M Quantity
Price

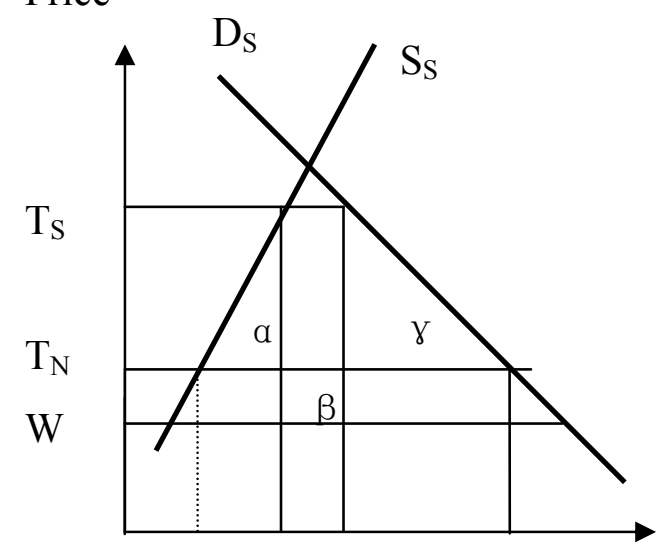

$\begin{array}{llllll}\mathrm{O} & \mathrm{L}^{\prime} & \mathrm{L} & \mathrm{N} & \mathrm{N}^{\prime} & \text { Quantity }\end{array}$

Adapted from Robson 1987, 26.

cost production of the Northern member to the lowest cost import from the outside world. Consequently, the static effect for the country in the South is positive. It is also good for the country in the North since the consumption and production stay the same. The government of the country in the North has tariff revenue which is represented by the square area in shadow. The outside world can also benefit from the establishment of the FTA. The export $\mathrm{L}^{\prime} \mathrm{N}^{\prime}$ from the Northern to the Southern country is bigger than the previous import $\mathrm{LN}$ from the outside world, that is $\mathrm{L}$ 'N $>\mathrm{LN}$. That means the export of the outside world increases ( $\mathrm{L} " \mathrm{M}>\mathrm{LN})$ and so does the income of the outside world. The reason for this increased export is that the demand of the country in South expands because of the lower price after the tariff is eliminated between the Southern and the Northern countries. 
Normally in a FTA, the country in the North always supplies the country in the South at the price TN or higher until its biggest quantity. The shortage on the market of the country in the North is solved by imports from the outside world. This kind of trade flow is called the Indirect Trade Deflection which means the original goods originally produced in the Northern market is substituted by products from the outside world. Even the rules of origin cannot reduce the indirect trade deflection.

\subsubsection{The second condition (Figure 3)}

When the demand curve of the country in the South is more elastic, it has an intersection E with the combined supply curve $\mathrm{S}_{\mathrm{N}+\mathrm{S}}$. The intersection decides the equilibrium price $\mathrm{P}_{\mathrm{FTA}}$

\section{Figure 3 The Static Effect of a FTA on Two Countries (b)}

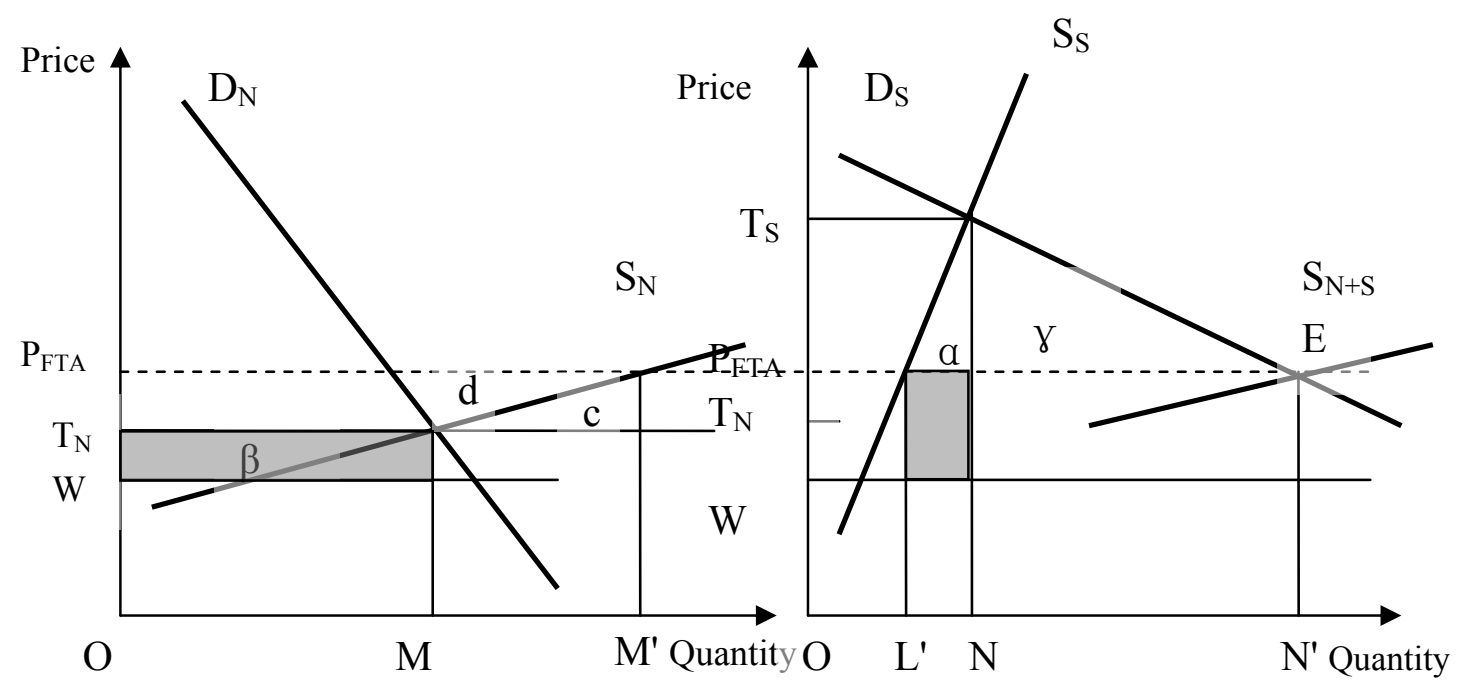

Adapted from Robson 1987, 29.

in the FTA which is higher than $\mathrm{T}_{\mathrm{N}}$. The prices of the same commodity are different on the

Northern and Southern markets. It is assumed that the supply curve of the country in the North is elastic and competitive. 
Before the FTA is established, both members have prohibitive tax. In that case, the North's equilibrium quantity is OM and the South's is ON. After the FTA is built, the supply of the North at the price $\mathrm{OT}_{\mathrm{N}}$ cannot satisfy the increased demand of the South. As a result the price on the Southern market climbs to $\mathrm{P}_{\mathrm{FTA}}$ and the South's import is $\mathrm{L}^{\prime} \mathrm{N}^{\prime}=\mathrm{OM}$. Under these circumstances, the country in the South has one trade creation effect $(\alpha+\gamma)$ and the country in the North has a producer surplus $\mathbf{d}$, because it produces and exports $\mathrm{OM}^{\prime}$ at a higher price $\mathrm{P}_{\mathrm{FTA}}$ and imports $\mathrm{OM}$ at a lower price $\mathrm{OW}$. The country in the North also suffers a negative production effect $\mathbf{c}$ which is conduced by the extra production MM' with more expensive cost. For the country in the North, the export revenue is $\mathrm{OP}_{\mathrm{FTA}} \times \mathrm{OM}^{\prime}$ and the cost of imports from the outside world is $\mathrm{OW} \times \mathrm{OM}$. This gives $\mathrm{OP}_{\mathrm{FTA}} \times \mathrm{OM}^{\prime}>\mathrm{OW} \times \mathrm{OM}$. As a result the static effect for the country in the North is positive and it also has a tariff revenue $\beta$. Similar to the first condition, the outside world again benefits because of the increased exports.

In conclusion, the FTA between countries in the North and South generally has a positive static effect for both members and even for the outside world. The effect derives from two aspects, the production effect and the consumption effect. The production effect comes from efficient production substituting inefficient production and the latter comes from the reduction of prices on the Southern market. However, the country in the South looses a large quantity of tariff revenue because of the trade liberalization in the free trade area. 


\subsection{Dynamic Effect of the China-New Zealand FTA and the China-Australia FTA}

This second section of chapter three moves on to look at the dynamic effect of the North-South FTAs. The section focuses on the competitive effect created by FTAs under the subjects, trade in goods, trade in services and investment creation.

\subsubsection{Competitive Effect of Trade in Goods}

The economic effects of FTAs are not limited to the static effects but also refer to the dynamic effects. One of the dynamic effects is the Competitive Effect which comes from fierce competition between companies of members of the RTA after the elimination of tariffs and market integration. The competitive effect results in the specialization of production and improves the efficiency of production. Due to the markets in the RTA opening to each other, local companies may face bigger and stronger rivals from companies in the member countries. At the same time this is also a great chance to occupy another member country's market. When companies from the country in the South consider their survival and development, they need to improve the operating system, efficiency of production and innovation after entering a North-South FTA.

The North-South FTA can help the Southern countries to improve their competitive ability in 3 ways. Firstly, when the companies of the developed countries use the cheap labour and resources from the developing countries they also bring the techniques and capital to their Southern partners. That helps the labour-intensive products of the Southern country to have more technical and capital ability. When the proportion of technical and capital ability to 
labour and resource is high enough the labour or resource intensive products change into technical or capital intensive products. That is a way for the developing counties to upgrade the products.

Secondly, due to investment facilitation in the North-South FTA, an increasing level of foreign direct investment (FDI) from the developed countries accelerates the developing countries' industrial restructuring. The technology spill over effect (Kokko 1993) helps the developing countries to upgrade their industrial structure gradually.

Finally, after the establishment of the North-South FTA, the companies from both sides face the same rules and markets but they are not at the same level of development. So it is compulsory for the companies in the South to optimize their operating systems, strengthen their effective management and improve their product efficiency to survive the struggling competition with their advanced rivals. The competition is an external stimulus for the Southern companies to activate their inefficient systems.

\subsubsection{The RCA Index}

The Revealed Comparative Advantage (RCA) Index is usually used to measure the trade comparative advantage of a country compared to the average level of the world. The formula is expressed as follows: 


$$
\mathrm{RCA}_{\mathrm{ij}}=\frac{X_{i j} / X_{i w}}{\sum_{i=1} X_{i j} / \sum_{i=1} X_{i w}}
$$

$\mathrm{RCA}_{\mathrm{ij}}$ is the comparative advantage of $\mathbf{j}$ country on $\mathbf{i}$ product;

$\mathrm{X}_{\mathrm{ij}}$ is the export of $\mathbf{i}$ product by $\mathbf{j}$ country;

$\mathrm{X}_{\mathrm{iw}}$ is the total export of $\mathbf{i}$ product by the whole world;

$\sum_{\mathrm{i}=1} \mathrm{X}_{\mathrm{ij}}$ is the total export of $\mathbf{j}$ country;

$\sum_{\mathrm{i}=1} \mathrm{X}_{\mathrm{iw}}$ is the total export of the whole world;

$\mathrm{X}_{\mathrm{ij}} / \mathrm{X}_{\mathrm{iw}}$ is $\mathrm{j}$ country's relative share to the world on i product;

$\sum_{\mathrm{i}=1} \mathrm{X}_{\mathrm{ij}} / \sum_{\mathrm{i}=1} \mathrm{X}_{\mathrm{iw}} \mathrm{j}$ country's relative share to the world on total export.

$0<\mathrm{RCA}_{\mathrm{ij}}<1$ means $\mathrm{j}$ country has a comparative disadvantage on $\mathrm{i}$ product; $\mathrm{RCA}_{\mathrm{ij}} \geqslant 1$ means $\mathrm{j}$ country has comparative advantage on i product. The bigger the RCA index the stronger the competitive ability.

The virtue of RCA is using the outcomes of trade to measure the comparative advantages of countries from the perspective of industries indirectly, rather than analyzing the trade structure directly. It reveals the comparative advantage of merchandise trade in circulation. Because the RCA Index calculation result is based on trade data it can avoid some strict assumptions which are usually necessary in some other calculation methods. The RCA Index method could also adjust to the practice of the international trade. However, the trade data is also the same reason for the RCA Index's defect. Because the trade data could 
be affected by temporary trade policies or other factors, this may cause the RCA index to distort the real competitive ability.

As mentioned earlier, it is assumed that the China-Australia FTA has already come into force. Considering the implementations of the China-New Zealand FTA and the Australia-New Zealand CER, the "global free trade" mode is formed among China, New Zealand and Australia (See figure 4). This means in the markets of China, New Zealand and Australia local companies have to compete with the rivals from the other two countries.

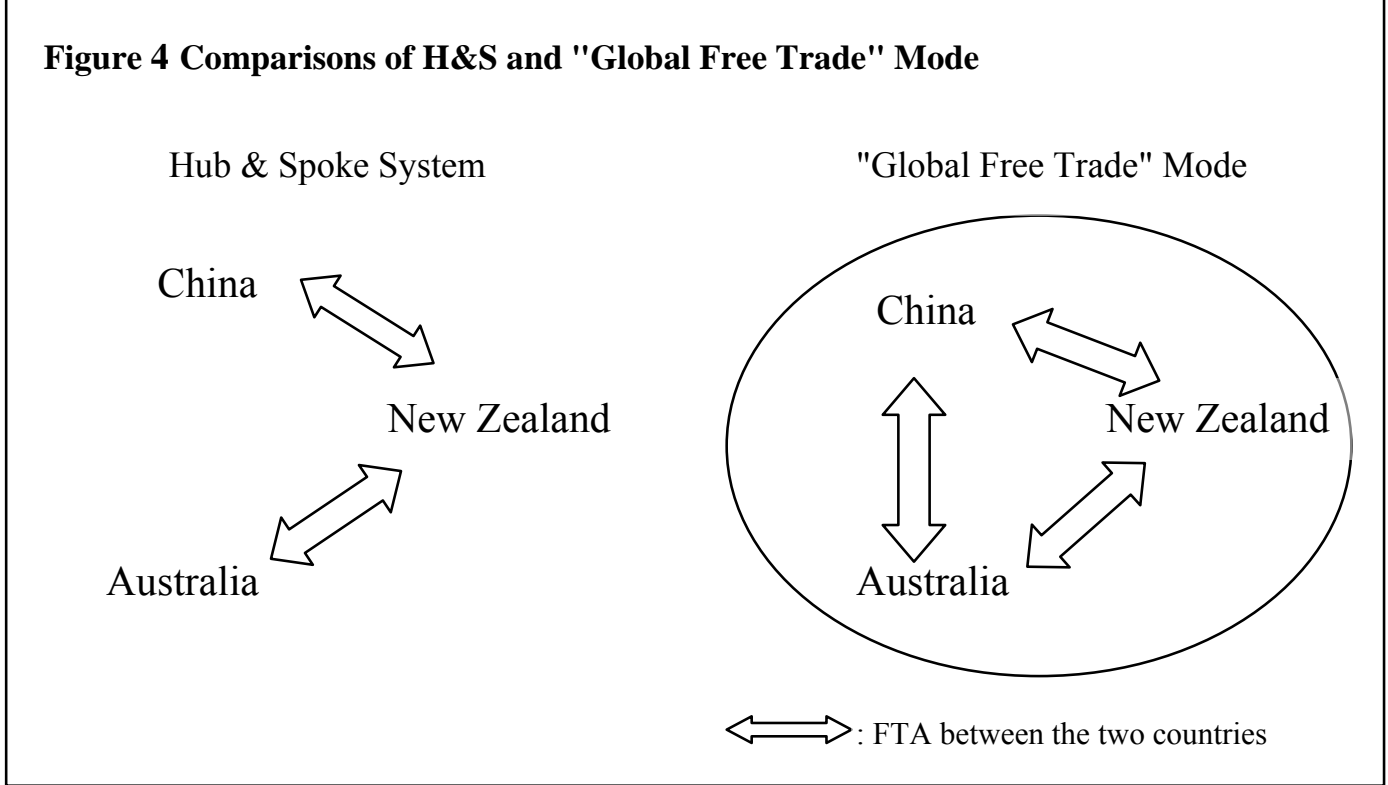

The analysis of the competitive effect of trade in goods was based on each market (China, New Zealand and Australia) separately. For example, the discussion about the competition on China's market followed four procedures. The first step was to compare the top 20 chapters of products (in HS Code) which were exported to China from Australia and New 
Zealand in five years between 2003 and 2007. ${ }^{10}$ The second step was to select the overlapped ones which were the products in competition. The next step was to calculate the RCA indexes of China, New Zealand and Australia on these competitive products. The outcomes of the RCA calculation show the advantages and disadvantages of China, New Zealand and Australia on products in competition. The last step was to compare the RCA indexes with the tariff reduction and predicted future competition. The analyses of the markets in China, Australia and New Zealand were done using these steps and the results are presented below.

\subsubsection{Competition in China's Market}

New Zealand mainly exports products of animal husbandry to China. Products of this type worth of 480 million US dollars were exported to China in 2007. This accounted for $33 \%$ of the total exports from New Zealand to China and was $17.5 \%$ higher than the previous year. Pulp of wood, wood and wood articles were the second and third largest chapters of exports from New Zealand to China in 2007. The values of these two chapters of export were 180 million US dollars and 170 million US dollars respectively. The proportion of wood pulp, wood and articles of wood to the total export from New Zealand to China were $12.7 \%$ and $12 \%$, with the growth rates of $44.4 \%$ and $9.1 \%$ respectively. (MOFCOM 2008)

After comparing the top 20 chapter export products from New Zealand to China every year between 2003 and 2007, the main exports were as follows: 02 (Meat and edible meat offal), 03 (Fish and crustaceans, molluscs and other aquatic invertebrates), 04 (Dairy produce;

\footnotetext{
${ }^{10}$ HS Code, The Harmonized Commodity Description and Coding System.
} 
birds eggs), 05 (Products of animal origin, not elsewhere specified), 15 (Animal or vegetable fats and oils), 19 (Preparations of cereals, flour, starch or milk; bakers' wares), 23 (Residues and wastes from the food industries), 26 (Ores, slag and ash), 35 (Albuminoids, modified starches, glues, enzymes), 41 (Raw hides and skins (other than fur skins) and leather), 44 (Wood and articles of wood, wood charcoal), 47 (Pulp of wood or of other fibrous cellulose material), 48 (Paper and paperboard; articles of paper pulp, of paper or of paperboard), 51 (Wool, fine or coarse animal hair; horsehair yarn and woven fabric), 74 (Copper and articles thereof), 76 (Aluminium and articles thereof), 84 (Machinery and mechanical appliances; parts thereof) and 85 (Electrical, electronic equipment). The details about the top 20 chapters of export from New Zealand to China are listed in the following table (products per annum are in descending order according to value and the original data was in Appendix 1).

Table 3 Export from New Zealand to China in HS Code 2003-2007

\begin{tabular}{l|llllllllllllllllllll}
\hline 2003 & 04 & 44 & 51 & 41 & 47 & 05 & 02 & 99 & 15 & 03 & 23 & 85 & 48 & 76 & 01 & 35 & 84 & 26 & 19 & 74 \\
2004 & 04 & 47 & 44 & 51 & 41 & 01 & 03 & 05 & 15 & 02 & 48 & 23 & 26 & 85 & 76 & 84 & 19 & 35 & 74 & 72 \\
2005 & 04 & 51 & 44 & 47 & 03 & 05 & 41 & 26 & 19 & 15 & 02 & 48 & 85 & 74 & 23 & 35 & 76 & 84 & 01 & 72 \\
2006 & 04 & 44 & 51 & 47 & 03 & 05 & 19 & 41 & 15 & 02 & 85 & 35 & 74 & 26 & 48 & 76 & 23 & 84 & 72 & 08 \\
2007 & 04 & 44 & 47 & 51 & 41 & 03 & 15 & 19 & 05 & 02 & 85 & 74 & 35 & 48 & 84 & 26 & 23 & 76 & 08 & 72 \\
\hline
\end{tabular}

Data source: UN Comtrade Database and MOFCOM, 2008.

The RCA Index is calculated according to the previously mentioned formula (1). The RCA indexes of these 18 chapters of China and New Zealand in 2007 are shown in Table 4. The calculation is also based on the data from Annex 7, 8 and 9 of the same document. 
Table 4 RCA Indexes of NeW Zealand and China on China's Market 2007

\begin{tabular}{lllllllllllllllllll}
\hline HS & 02 & 03 & 04 & 05 & 15 & 19 & 23 & 26 & 35 & 41 & 44 & 47 & 48 & 51 & 74 & 76 & 84 & 85 \\
\hline NZ & 21.89 & 8.81 & 50.36 & 18.80 & 1.63 & 7.08 & 2.22 & 0.18 & 21.996 .73 & 7.63 & 7.72 & 1.26 & 21.40 & 0.53 & 4.10 & 0.44 & 0.26 \\
China & 0.11 & 1.14 & 0.09 & 2.29 & 0.11 & 0.30 & 0.33 & 0.16 & 0.64 & 0.52 & 1.07 & 0.03 & 0.52 & 1.73 & 0.61 & 0.94 & 1.59 & 2.25 \\
\hline
\end{tabular}

Data source: UN Comtrade Database, 2008.

As the table shows, China has a greater advantage than New Zealand in only three chapters: 74 (Copper and articles thereof), 84 (Machinery and mechanical appliances; parts thereof) and 85 (Electrical, electronic equipment). Both China and New Zealand have similar disadvantages on chapter 26 (Ores, slag and ash). The RCA indexes of China are far behind New Zealand's in all other 14 chapters. The RCA indexes of China are above the world average level on 03 (Fish and crustaceans, molluscs and other aquatic invertebrates), 05 (Products of animal origin, not elsewhere specified), 44 (Wood and articles of wood, wood charcoal) and 51 (Wool, fine or coarse animal hair; horsehair yarn and woven fabric). However, the competitiveness of New Zealand on these four chapters is incomparable to China's. Furthermore, the difference in competitiveness between China and New Zealand is enormous on chapter 04 (Dairy produce; bird's eggs; natural honey). The RCA index of New Zealand on chapter 04 is 50.36 but the number for China is only 0.09 . This means that trade liberalization will most likely result in destructive damage on uncompetitive Chinese producers in the Chinese market in this area.

From Table 4, we can see the great difference between China and New Zealand on the productivity of animal husbandry and forestry. All 14 chapters in which China is disadvantaged are in the tariff schedule of the China-New Zealand FTA. The tariff on chapter 02 (Meat and edible meat offal) will drop to $0 \%$ from $15.56 \%$ before 2016 . The 
tariffs on chapters 04 (Dairy produce; birds eggs; natural honey), 05 (Products of animal origin, not elsewhere specified), 35 (Albuminoids, modified starches, glues, enzymes) and 51 (Wool, fine or coarse animal hair; horsehair yarn and woven fabric) will drop from $12.53 \%, 9.75 \%, 7.54 \%$ and $5.00 \%$ respectively to $0 \%$ (MOFCOM 2008). After the loss of this high tariff protection the animal husbandry and forestry industries of China will suffer the effects of competition and most likely negatively impact on the profitability of these producers. The proposed FTA between China and Australia will also greatly impact on China's economy.

The main export (in HS Code) from Australia to China in the five years between 2003 and 2007 were the chapters as follows: 10 (Cereals), 15 (Animal or vegetable fats and oils), 26 (Ores, slag and ash), 27 (Mineral fuels, mineral oils and products of their distillation), 32 (Tanning or dyeing extracts), 39 (Plastics and articles thereof), 41 (Raw hides and skins (other than fur skins) and leather), 44 (Wood and articles of wood, wood charcoal), 51 (Wool, fine or coarse animal hair; horsehair yarn and woven fabric), 52 (Cotton), 72 (Iron and steel), 74 (Copper and articles thereof), 75 (Nickel and articles thereof), 76 (Aluminium and articles thereof), 84 (Machinery and mechanical appliances; parts thereof) and 85 (Electrical, electronic equipment). The details of the top 20 chapters of export from Australia to China are presented in Table 5 (products per annum are in descending order according to value and the original data is in Appendix 3). The RCA indexes of Australia and China for the products of the competitive 16 chapters are presented in Table 6 . The calculation was based on the data from Appendixes 7,8 and 9. 
TABle 5 EXPORT from Australia to China in HS CODE 2003-2007

\begin{tabular}{l|llllllllllllllllllll}
\hline 2003 & 26 & 27 & 51 & 99 & 76 & 72 & 84 & 41 & 74 & 32 & 10 & 85 & 15 & 01 & 48 & 44 & 75 & 39 & 90 & 52 \\
2004 & 26 & 51 & 27 & 76 & 84 & 10 & 74 & 41 & 52 & 72 & 32 & 75 & 01 & 15 & 85 & 44 & 03 & 02 & 39 & 04 \\
2005 & 26 & 51 & 27 & 76 & 52 & 84 & 10 & 74 & 41 & 32 & 75 & 03 & 85 & 44 & 15 & 72 & 71 & 79 & 39 & 30 \\
2006 & 26 & 51 & 27 & 76 & 74 & 41 & 75 & 52 & 84 & 10 & 79 & 32 & 85 & 30 & 44 & 15 & 39 & 47 & 03 & 72 \\
2007 & 26 & 51 & 27 & 75 & 41 & 76 & 84 & 74 & 15 & 52 & 30 & 85 & 39 & 32 & 44 & 79 & 47 & 72 & 10 & 04 \\
\hline
\end{tabular}

Data source: UN Comtrade Database and MOFCOM, 2008.

Table 6 RCA IndeXes of Australia and China on China's Market 2007

\begin{tabular}{llllllllllllllllll}
\hline HS & 10 & 15 & 26 & 27 & 32 & 39 & 41 & 44 & 51 & 52 & 72 & 74 & 75 & 76 & 84 & 85 \\
\hline Aus & 3.52 & 1.12 & 33.42 & 2.81 & 0.86 & 0.23 & 3.54 & 1.13 & 16.33 & 1.35 & 0.38 & 2.90 & 3.76 & 3.72 & 0.29 & 0.16 \\
China & 0.36 & 0.11 & 0.16 & 0.20 & 0.69 & 0.75 & 0.52 & 1.07 & 1.73 & 2.97 & 1.26 & 0.61 & 0.20 & 0.94 & 1.59 & 2.25 \\
\hline
\end{tabular}

Data source: UN Comtrade Database, 2008.

Compared to Australia, China has better RCA indexes on chapters 39 (Plastics and articles thereof), 52 (Cotton), 72 (Iron and steel), 84 (Machinery and mechanical appliances; parts thereof) and 85 (Electrical, electronic equipment). However, the advantages of China on these 5 chapters are limited because the differences between China and Australia are small. The competition between Australia and China will be fierce on chapter 44 (Wood and articles of wood, wood charcoal) because the RCA indexes of both countries are close to each other and higher than the average level of the world. Australia has absolute advantages on the other 9 chapters, namely 10 (Cereals), 15 (Animal or vegetable fats and oils), 26 (Ores, slag and ash), 27 (Mineral fuels, mineral oils and products of their distillation), 41 (Raw hides and skins (other than fur skins) and leather), 51 (Wool, fine or coarse animal hair; horsehair yarn and woven fabric), 74 (Copper and articles thereof), 75 (Nickel and articles thereof) and 76 (Aluminium and articles thereof). The advantages of Australia on these 9 chapters will be more significant after the high tariffs are eliminated, 
which are $24.5 \%$ for cereals, $11.2 \%$ for fats and oils, $7.9 \%$ for minerals and metals, $13.5 \%$ for leather.

TABle 7 TARIfFs OF China

\begin{tabular}{l|lll|lll}
\hline & \multicolumn{3}{|l|}{ Final bound duties } & \multicolumn{3}{l}{ MFN applied duties } \\
\hline Product groups & AVG & $\begin{array}{l}\text { Duty-free } \\
\text { in } \%\end{array}$ & Max & AVG & $\begin{array}{l}\text { Duty-free } \\
\text { in } \%\end{array}$ & Max \\
\hline Animal products & 14.8 & 9.4 & 25 & 14.8 & 10.1 & 25 \\
Dairy products & 12.2 & 0 & 20 & 12.2 & 0 & 20 \\
Fruit, vegetables, plants & 15 & 4.8 & 30 & 14.9 & 5.3 & 30 \\
Coffee, tea & 14.9 & 0 & 32 & 14.9 & 0 & 32 \\
Cereals \& preparations & 23.7 & 2.6 & 65 & 24.5 & 3.4 & 65 \\
Oilseeds, fats \& oils & 11.6 & 6.2 & 30 & 11.2 & 5.4 & 30 \\
Sugars and confectionery & 27.4 & 0 & 50 & 27.4 & 0 & 50 \\
Beverages \& tobacco & 24.1 & 2.5 & 65 & 23 & 2.2 & 65 \\
Cotton & 22 & 0 & 40 & 22 & 0 & 40 \\
Other agricultural products & 11.9 & 10.2 & 38 & 11.7 & 9.1 & 38 \\
Fish \& fish products & 11 & 6.7 & 23 & 10.9 & 6.2 & 23 \\
Minerals \& metals & 8 & 5.7 & 50 & 7.9 & 5.8 & 50 \\
Petroleum & 3.3 & 50.0 & 9 & 5.1 & 20.0 & 9 \\
Chemicals & 6.7 & 0.5 & 47 & 6.9 & 0.4 & 47 \\
Wood, paper, etc. & 5 & 23.0 & 20 & 4.6 & 35.3 & 20 \\
Textiles & 9.7 & 0.2 & 38 & 9.7 & 0 & 38 \\
Clothing & 16.2 & 0 & 25 & 16 & 0 & 25 \\
Leather, footwear, etc. & 13.7 & 0.7 & 25 & 13.5 & 0.6 & 25 \\
Non-electrical machinery & 8.4 & 7.9 & 35 & 8.3 & 8.8 & 35 \\
Electrical machinery & 8.8 & 26.6 & 35 & 9 & 24.0 & 35 \\
Transport equipment & 11.5 & 0.8 & 45 & 11.5 & 0.8 & 45 \\
Manufactures & 12.3 & 14.9 & 35 & 12.2 & 9.7 & 35 \\
\hline Adapted fro WTO Statstcs Dat & $56,2008$. & & & & \\
\hline
\end{tabular}

Adapted from WTO Statistics Database, 2008.

The tariff level of China is normally high on agricultural products which are competitive for both China and Australia. The duty-free proportion of China is quite low. Australia will benefit a lot from tariff elimination after the China-Australia FTA comes into force. The benefit for Australia is not only the duties saving but also the promotion of their 
competitive ability. Table 7 presents the tariff level of China and Australia as applicable to the MFN (Most Favoured Nation) duties.

Comparing Table 3 and Table 5, the competition among China, Australia and New Zealand will be on chapters $15,26,41,44,51,74,76,84$ and 85 . The RCA indexes of China, New Zealand and Australia on these 9 chapters are presented in Table 8. Both Australia and New Zealand will be unable to compete with China on chapters 84 (Machinery and mechanical appliances; parts thereof)and 85 (Electrical, electronic equipment). However, China falls behind Australia and New Zealand on the other 7 chapters. Australia shows great competitiveness on chapters 26 (Ores, slag and ash) and 74 (Copper and articles thereof) while New Zealand has the best RCA indexes on chapters 15 (Animal or vegetable fats and oils), 41 (Raw hides and skins (other than fur skins) and leather), 44(Wood and articles of wood, wood charcoal), 51 (Wool, fine or coarse animal hair; horsehair yarn and woven fabric) and 76 (Aluminium and articles thereof).

Table 8 RCA of New Zealand, Australia and China on China's Market 2007

\begin{tabular}{llllllllll}
\hline HS & 15 & 26 & 41 & 44 & 51 & 74 & 76 & 84 & 85 \\
\hline New Zealand & 1.63 & 0.18 & 6.73 & 7.63 & 21.40 & 0.53 & 4.10 & 0.44 & 0.26 \\
Australia & 1.12 & 33.42 & 1.13 & 1.13 & 16.33 & 2.90 & 3.72 & 0.29 & 0.16 \\
China & 0.11 & 0.16 & 1.07 & 1.07 & 1.73 & 0.61 & 0.94 & 1.59 & 2.25 \\
\hline
\end{tabular}

Data source: UN Comtrade Database, 2008.

On the down side for China is their competitive ability in products such as meat, products of animal origin, dairy produce, wool and cattle husbandry. China's status quo for cattle husbandry is low cultivation and processing standards with poor equipment compared to the international average. In addition the deficiencies for China in cattle husbandry are 
lacking technology, lacking an economy of scale and the fact that suppliers in this market are still small farmers. The gap between China and its developed partners in this area is enormous. The differences are not only on the quality of products and the standard of health quarantine procedures, but also on the economy scale of the whole cattle husbandry industry. It is difficult for cattle husbandry farmers from China to compete with the developed and large-scale companies from New Zealand and Australia.

The free trade of cattle husbandry does not only have an impact on the economy of China but also has an influence on social stability in China. Because most ranches in China are occupied by people from minority ethnic groups such as Inner Mongolia, Xinjiang, Gansu and Tibet provinces, stockbreeding is the main source of income for the minority ethnic people. If the market of cattle husbandry in China is occupied by the advanced companies from Australia and New Zealand those minority ethnic people will lose their income. The unemployed population will be mainly from minority ethnic groups which will create an extremely sensitive problem for the Chinese government.

On the upside, although China is traditionally a big agricultural country, China's available arable land per capita equals only $2 / 5^{\text {th }}$ of the world's average level and the level of China's available pasture land per capita is half of the world's average level (National Bureau of Statistics of China 2006). At the same time, increasing urbanization and industrialization result in the shrinking of agricultural land in China every year. In 2007, China's arable land and pasture land both were decreased by $0.03 \%$ compared to 2006 . The reduction of arable land and pastoral land were 40.7 thousand hectares and 67.4 thousand hectares respectively 
(China Ministry of Land and Resources 2007). Under these circumstances, the FTAs creation of increased competition in animal husbandry from New Zealand and Australia will lessen the stress on pastoral land through increased import of animal husbandry products. Similarly, the situation for available forest land will be improved if China imports more products of forestry from New Zealand and Australia. In the long term, the increased import of cattle husbandry and forestry products will help China reduce soil erosion, save water and improve the ecological environment. The increased export of cattle husbandry and forestry products will also provide New Zealand and Australia with more export revenue and more employment opportunities. Overall, the competition created by the FTAs, though leading to a period of economic adjustment with social consequences, will benefit China's domestic economy in the long term.

\subsubsection{Competition in New Zealand's Market}

Competition created by the China-New Zealand FTA in the New Zealand market will not be fierce because China already has almost open market access on most of the products it exports to New Zealand. However, textiles, clothes and shoes from China will benefit a lot due to the establishment of China-New Zealand FTA.

New Zealand mainly imports electrical products, textiles, toys and furniture, base metals and chemical products from China. The import values of these five kinds of products amounted to 3 billion US dollars in 2007 , accounting for $77.6 \%$ of the total imports from China that year (MOFCOM 2008). In New Zealand's market, the rivals of China on these products are the United States and Australia. Considering the Closer Economic Relations 
Trade Agreement between New Zealand and Australia and the fact that there is no preferential agreement between the United States and New Zealand to date, the competition on these products is mainly among New Zealand, China and Australia.

After comparing the top 20 export products from China to New Zealand in the five years between 2003 and 2007, the 19 chapters in competition are listed as follows: 28 (Inorganic chemicals), 29 (Organic chemicals), 39 (Plastics and articles thereof), 42 (Articles of leather, saddlery and harness), 48 (Paper and paper board; articles of paper pulp, of paper or of paperboard), 61 (Articles of apparel, accessories, knitted or crocheted), 62 (Articles of apparel, accessories, not knitted or crocheted), 63 (Other made up textile articles; sets; worn clothing and worn textile article), 64 (Footwear, gaiters and the like; parts of such articles), 69 (Ceramic products), 70 (Glass and glass wear), 73 (Articles of iron and steel), 82 (Tools, implements, cutlery, spoons and forks, of base metal), 84 (Machinery and mechanical appliances; parts thereof), 85 (Electrical, electronic equipment), 87 (Vehicles other than railway or tramway rolling stock), 90 (Optical, photo, technical, medical, etc apparatus), 94 (Furniture; bedding, mattress, Cushions and similar stuffed furnishing) and 95 (Miscellaneous manufactured articles). Details about the top 20 chapters of export from China to New Zealand are presented in Table 9 (products per annum are in descending order according to value and the original data is in Appendix 2). The RCA indexes of China and New Zealand on the 19 chapters in competition are shown in Table 10. The calculation was based on the data in Appendixes 7,8 and 9. 
Table 9 EXPort from China to NeW Zealand in HS Code 2003-2007

\begin{tabular}{l|llllllllllllllllllll}
\hline 2003 & 85 & 84 & 61 & 62 & 95 & 64 & 94 & 63 & 39 & 73 & 90 & 42 & 87 & 28 & 69 & 70 & 48 & 82 & 25 & 29 \\
2004 & 85 & 84 & 61 & 62 & 94 & 95 & 64 & 73 & 39 & 63 & 90 & 42 & 87 & 28 & 82 & 70 & 69 & 48 & 29 & 40 \\
2005 & 84 & 85 & 61 & 62 & 94 & 95 & 64 & 73 & 39 & 63 & 90 & 42 & 87 & 48 & 70 & 28 & 29 & 69 & 82 & 40 \\
2006 & 84 & 85 & 61 & 62 & 94 & 95 & 64 & 73 & 39 & 63 & 90 & 42 & 48 & 87 & 70 & 28 & 69 & 82 & 40 & 29 \\
2007 & 85 & 84 & 61 & 62 & 94 & 95 & 73 & 64 & 39 & 63 & 42 & 87 & 48 & 70 & 90 & 29 & 40 & 69 & 28 & 82 \\
\hline
\end{tabular}

Data source: UN Comtrade Database and China MOFCOM, 2008.

Table 10 RCA Indexes of China ANd New Zealand on New Zealand's Market 2007

\begin{tabular}{llllllllllllllllllll}
\hline HS & 28 & 29 & 39 & 42 & 48 & 61 & 62 & 63 & 64 & 69 & 70 & 73 & 82 & 84 & 85 & 87 & 90 & 94 & 95 \\
\hline China & 1.28 & 0.75 & 0.75 & 4.07 & 0.52 & 5.15 & 4.12 & 5.12 & 4.12 & 2.22 & 1.53 & 1.85 & 1.88 & 1.59 & 2.25 & 0.33 & 1.19 & 2.88 & 3.95 \\
NZ & 0.09 & 0.07 & 0.42 & 0.15 & 1.26 & 0.30 & 0.42 & 0.74 & 0.32 & 0.08 & 0.19 & 0.47 & 0.61 & 0.44 & 0.26 & 0.09 & 0.57 & 0.53 & 0.22 \\
\hline
\end{tabular}

Data source: UN Comtrade Database, 2008.

As shown in Table 10, China has better RCA indexes than New Zealand on 18 chapters except chapter 48 (Paper and paper board; articles of paper pulp, of paper or of paperboard), that is to say, China is more competitive on these 18 chapters. Furthermore, all 19 chapters are in the tariff schedule of the China-New Zealand FTA. Although the tariffs are extremely low for most of the 19 chapters, (some of them are already duty free such as chapters 28, 29 and 48), China will still benefit a lot from the tariff reduction on chapters 61,62 and 64 . The duties for these three chapters are almost the highest in the tariff structure of New Zealand and will drop to $0 \%$ from $15.2 \%, 15.5 \%$ and $9.9 \%$ before 2016 (NZMFAT 2008). The tariffs for the other chapters are around 5\%. The duty reduction will bring more competitive advantages for China on these products.

Since Australia is the biggest rival of China in New Zealand's market, it is necessary to observe which chapters are in competition between China and Australia. The main exports from Australia to New Zealand in the five years between 2003 and 2007 were the 17 
chapters of $19,21,22,27,28,30,32,39,49,72,73,76,84,85,87$ and $90 .{ }^{11}$ The details of the top 20 chapters of export from Australia to New Zealand during the five years are presented in Table 11 (products per annum are in descending order according to value and the original data is in Appendix 6).

Table 11 Exports from Australia to New Zealand in HS Code 2003-2007

\begin{tabular}{l|llllllllllllllllllll}
\hline 2003 & 87 & 27 & 84 & 48 & 85 & 39 & 28 & 30 & 49 & 22 & 73 & 72 & 21 & 19 & 76 & 90 & 33 & 17 & 32 & 20 \\
2004 & 27 & 87 & 84 & 48 & 85 & 28 & 39 & 72 & 30 & 73 & 49 & 22 & 21 & 19 & 76 & 90 & 33 & 17 & 32 & 20 \\
2005 & 27 & 87 & 84 & 85 & 48 & 39 & 28 & 30 & 73 & 72 & 49 & 22 & 19 & 21 & 90 & 76 & 17 & 33 & 74 & 32 \\
2006 & 27 & 87 & 84 & 85 & 28 & 48 & 39 & 30 & 72 & 73 & 22 & 74 & 19 & 49 & 21 & 76 & 17 & 90 & 33 & 32 \\
2007 & 27 & 87 & 84 & 85 & 48 & 28 & 30 & 39 & 72 & 73 & 19 & 22 & 49 & 21 & 76 & 90 & 74 & 17 & 32 & 38 \\
\hline
\end{tabular}

Data source: Statistics New Zealand 2008.

After comparing Table 11 and Table 9, the overlapping 7 chapters are listed as follows: 28 (Inorganic chemicals), 39 (Plastics and articles thereof), 73 (Articles of iron or steel), 84 (Machinery and mechanical appliances; parts thereof), 85 (Electrical, electronic equipment), 87 (Vehicles other than railway or tramway rolling stock) and 90 (Optical, photo, technical, medical, etc apparatus). The RCA indexes of China, Australia and New Zealand are presented in Table 12 which shows the three countries' competitive abilities on the 7 chapters. The calculation is based on the data in Appendixes 7, 8 and 9.

\footnotetext{
${ }^{11}$ These chapters are: 19-Preparations of cereals, flour, starch or milk; bakers' wares. 21-Miscellaneous edible preparations. 22-Beverages, spirits and vinegar. 23-Residues and wastes from the food industries. 27-Mineral fuels, mineral oils and products of their distillation. 28-Inorganic chemicals.

30-Pharmaceutical products. 32-Tanning or dyeing extracts. 39-Plastics and articles thereof.

49-Printed books, newspapers, pictures and other products of the printing industries. 72 - Iron and steel.

73-Articles of iron or steel. 76-Aluminium and articles thereof. 84-Machinery and mechanical appliances; parts thereof. 85-Electrical, electronic equipment. 87-Vehicles other than railway or tramway rolling stock. 90 - Optical, photo, technical, medical, etc apparatus.
} 
Australia has the best competitiveness on chapter 28 (Inorganic chemicals). However, the situation reverses for Australia on the other 6 chapters. China has the best RCA indexes on the other 6 chapters but the competitive advantages of China are limited on chapter 39 (Plastics and articles thereof) and 87 (Vehicles other than railway or tramway rolling stock), because the competitiveness of China, Australia and New Zealand are really close to each other on these two chapters.

Table 12 RCA Indexes of China, Australia and New Zealand on New Zealand's

MARKET 2007

\begin{tabular}{llllllll}
\hline HS & 28 & 39 & 73 & 84 & 85 & 87 & 90 \\
\hline China & 1.28 & 0.75 & 1.85 & 1.59 & 2.25 & 0.33 & 1.19 \\
Australia & 6.42 & 0.23 & 0.31 & 0.29 & 0.16 & 0.32 & 0.58 \\
New Zealand & 0.09 & 0.42 & 0.47 & 0.44 & 0.26 & 0.09 & 0.57 \\
\hline
\end{tabular}

Data source: UN Comtrade Database, 2008.

In general, China will not face fierce competition from New Zealand except in chapter 48

(Paper and paper board; articles of paper pulp, of paper or of paperboard). Due to tariff elimination China will benefit a lot on chapters 61 (Articles of apparel, accessories, knitted or crocheted), 62 (Articles of apparel, accessories, not knitted or crocheted) and 64 (Footwear, gaiters and the like; parts of such articles). However, China will most likely have severe competition from Australia on chapters 39 (Plastics and articles thereof) and 87 (Vehicles other than railway or tramway rolling stock) especially as China has competitive disadvantages compared to the average level of the world on these two chapters. 


\subsubsection{Competition in Australia's Market}

Australia mainly imports from China manufacturing products such as electrical equipments, textiles, toys and furniture. The import value of these products was 15.93 billion US dollars in 2007 accounting for $66.2 \%$ of total imports from China in that year. These products from China are predominant in Australia's market. As a result, the competitive situation will not change a lot for China in the Australian market if the proposed FTA is ratified.

Specifically, Australia's main imports from China in the five years between 2003 and 2007 are the following 17 chapters: 29 (Organic chemicals), 39 (Plastics and articles thereof), 42 (Articles of leather, saddlery and harness), 48 (Paper and paperboard; articles of paper pulp, of paper or of paperboard), 61 (Articles of apparel, accessories, knitted or crocheted), 62 (Articles of apparel, accessories, not knitted or crocheted), 63 (Other made up textiles articles; sets; worn clothing and worn textile article), 64 (Footwear, gaiters and the like; parts of such articles), 69 (Ceramic products), 73 (Articles of iron and steel), 76 (Aluminium and articles thereof), 84 (Machinery and mechanical appliances; parts thereof), 85 (Electrical, electronic equipment), 87 (Vehicles other than railway or tramway rolling stock), 90 (Optical, photo, technical, medical, etc apparatus), 94 (Furniture; bedding, mattress, cushions and similar stuffed furnishing) and 95 (Toys, games and sports requisites; parts and accessories thereof). Details of the top 20 chapters of exports from China to Australia are shown in Table 13 (products per annum are in descending order according to value and the original data is in Annex 4). The RCA indexes of China and 
Australia on these 17 chapters in competition are presented in Table 14. The calculation is based on the data in Appendixes 7, 8 and 9.

TABle 13 EXPort from China to Australia in HS CODE 2003-2007

\begin{tabular}{l|llllllllllllllllllll}
\hline 2003 & 84 & 85 & 61 & 62 & 94 & 73 & 95 & 27 & 63 & 39 & 64 & 42 & 76 & 87 & 29 & 69 & 48 & 70 & 90 & 28 \\
2004 & 84 & 85 & 61 & 62 & 95 & 94 & 64 & 73 & 39 & 63 & 42 & 90 & 87 & 27 & 76 & 29 & 48 & 69 & 82 & 83 \\
2005 & 84 & 85 & 62 & 61 & 94 & 95 & 73 & 64 & 39 & 90 & 63 & 42 & 72 & 87 & 76 & 48 & 27 & 29 & 40 & 69 \\
2006 & 84 & 85 & 62 & 61 & 94 & 95 & 73 & 64 & 39 & 63 & 87 & 42 & 90 & 76 & 48 & 40 & 29 & 69 & 72 & 83 \\
2007 & 85 & 84 & 61 & 62 & 94 & 95 & 73 & 39 & 64 & 87 & 63 & 42 & 76 & 40 & 48 & 29 & 90 & 72 & 69 & 83 \\
\hline
\end{tabular}

Data source: UN Comtrade Database and China MOFCOM, 2008.

Table 14 RCA IndeXes of China ANd Australia on Australia's Market 2007

\begin{tabular}{llllllllllllllllll}
\hline HS & 29 & 39 & 42 & 48 & 61 & 62 & 63 & 64 & 69 & 73 & 76 & 84 & 85 & 87 & 90 & 94 & 95 \\
\hline China & 0.75 & 0.75 & 4.07 & 0.52 & 5.15 & 4.12 & 5.12 & 4.12 & 2.22 & 1.85 & 0.94 & 1.59 & 2.25 & 0.33 & 1.19 & 2.88 & 3.95 \\
Australia & 0.04 & 0.23 & 0.09 & 0.40 & 0.06 & 0.07 & 0.23 & 0.05 & 0.21 & 0.31 & 3.72 & 0.29 & 0.16 & 0.32 & 0.58 & 0.14 & 0.44 \\
\hline
\end{tabular}

Data source: UN Comtrade Database, 2008.

As shown in the tables, China has absolute advantages compared to Australia on most of the products except three chapters which are chapters 48 (Paper and paperboard; articles of paper pulp, of paper or of paperboard), 76 (Aluminium and articles thereof) and 87 (Vehicles other than railway or tramway rolling stock). The RCA Index superiorities of China are quite limited on chapters 39, 48 and 87 and they are all less than 1. As a result, the competition between China and Australia will most likely be fierce on these three chapters. China may even face competition from other countries with similar products. The automotive industry in Australia is a key industry which receives great assistance and support from the Australian government. Considering the disadvantage of China in the automotive industry compared to the average level of the world, China will not have the ability to compete with Australian companies in the Australian market on chapter 87. 
Australia has much better RCA than China in chapter 76. However, Australia's duty on mine and metal is currently just $2.8 \%$. Consequently, the gap between China and Australia in the mine and metal industry will not be narrowed even after the proposed Australia-China FTA comes into force. The tariffs operating in Australia are shown in Table 15. China receives the MFN duties in the Australian tariff structure.

TABle 15 Tariffs Of Australia

\begin{tabular}{|c|c|c|c|c|c|c|}
\hline \multirow[b]{2}{*}{ Product groups } & \multicolumn{3}{|c|}{ Final bound duties } & \multicolumn{3}{|c|}{ MFN applied duties } \\
\hline & AVG & $\begin{array}{l}\text { Duty-free } \\
\text { in } \%\end{array}$ & $\operatorname{Max}$ & AVG & $\begin{array}{l}\text { Duty-free } \\
\text { in } \%\end{array}$ & Max \\
\hline Animal products & 1.6 & 75.3 & 16 & 0.4 & 91.2 & 5 \\
\hline Dairy products & 4.4 & 20.0 & 21 & 4.1 & 75.0 & 21 \\
\hline Fruit, vegetables, plants & 3.6 & 23.6 & 29 & 1.6 & 68.9 & 5 \\
\hline Coffee, tea & 3.9 & 50.0 & 17 & 1 & 79.2 & 5 \\
\hline Cereals \& preparations & 2.5 & 31.7 & 17 & 1.3 & 72.4 & 5 \\
\hline Oilseeds, fats \& oils & 2.9 & 31.6 & 14 & 1.6 & 67.4 & 5 \\
\hline Sugars and confectionery & 7 & 0 & 15 & 1.9 & 59.4 & 5 \\
\hline Beverages \& tobacco & 10.3 & 3.8 & 25 & 3.6 & 28.8 & 5 \\
\hline Cotton & 1.2 & 40.0 & 2 & 0 & 100.0 & 0 \\
\hline Other agricultural products & 1.9 & 31.0 & 20 & 0.3 & 94.7 & 5 \\
\hline Fish \& fish products & 0.8 & 80.4 & 10 & 0 & 99.2 & 5 \\
\hline Minerals \& metals & 6.7 & 21.2 & 45 & 2.8 & 45.3 & 10 \\
\hline Petroleum & 0 & 100.0 & 0 & 0 & 100.0 & 0 \\
\hline Chemicals & 9.1 & 8.7 & 55 & 1.8 & 64.3 & 18 \\
\hline Wood, paper, etc. & 7 & 26.2 & 25 & 3.4 & 33.2 & 10 \\
\hline Textiles & 18.3 & 14.2 & 55 & 6.8 & 16.3 & 18 \\
\hline Clothing & 41.1 & 6.7 & 55 & 15.4 & 8.0 & 18 \\
\hline Leather, footwear, etc. & 14.4 & 12.7 & 55 & 5.5 & 16.7 & 18 \\
\hline Non-electrical machinery & 8.2 & 18.5 & 50 & 3.1 & 43.4 & 10 \\
\hline Electrical machinery & 10.3 & 30.7 & 45 & 3.2 & 42.2 & 10 \\
\hline Transport equipment & 12.6 & 9.0 & 40 & 5.9 & 34.5 & 245 \\
\hline Manufactures, n.e.s. & 6.3 & 33.2 & 40 & 1.4 & 73.5 & 10 \\
\hline
\end{tabular}

Adapted from WTO Statistics Database, 2008.

For most Australia is an open market to the world. Most of its duties are quite low except in the textile and clothing sectors. These two sectors with the highest duties are also the 
main export sectors from China to Australia. Although China receives the MFN duties, the tariffs for textiles, clothing and footwear are still high at $6.8 \%, 15.4 \%$ and $5.5 \%$ respectively. The proportion of duty-free for these three sectors are relatively low which only are $16.3 \%, 8.0 \%$ and $16.7 \%$. These sectors' tariffs are the highest in Australia's duty structure.

However, Australia announced to reduce the tariffs of textiles and articles thereof since $1^{\text {st }}$ January 2005. The specific policy about the removal of tariffs is listed as follows: The tariff of clothing and articles reduces to $17.5 \%$ from $25 \%$; The tariffs of footwear, cotton sheet, carpets and articles knitted reduce to $10 \%$ from 15\%; The tariffs of sleeping bags, table cloth and parts of footwear reduce to $7.5 \%$ from $10 \%$; The tariffs of yarn and thread used in textiles, articles of leather maintained at 5\%. (MOFCOM 2006)

This duty-reduction on textiles and clothing could cause Australia's market to be occupied by the influx of textile exports from the whole world. In that case, China has to compete with other countries for Australia's textiles market. However, in the condition that the China-Australia FTA enters into force, China would share a bigger part of Australia's textiles market because of the further textile duty-reduction making Chinese textiles more competitive in the Australian market.

Generally, the competition between China and Australia in Australia's market will not be too intense except on chapters 48 (Paper and paperboard; articles of paper pulp, of paper or of paperboard), 76 (Aluminium and articles thereof) and 87 (Vehicles other than railway or 
tramway rolling stock). China will benefit a lot on textiles, clothing and footwear sectors due to the trade liberalization proposed in the China-Australia FTA.

\subsubsection{Competitive Effect of Trade in Services}

Services are the most dynamic component of economies for both developed and developing countries. The General Agreement on Trade in Service (GATS) of the WTO was signed on Uruguay Round on 1994. The GATS gives explicit concepts of the services modes. The definition of services trade under the GATS is four-pronged, depending on the territorial presence of the supplier and the consumer at the time of the transaction. The four modes are:

Mode 1 - Cross-border trade: from the territory of one member into the territory of any other member. This mode is usually implemented through telecommunications or postal infrastructure without labour movement such as consulting by international calls.

Mode 2 - Consumption abroad: in the territory of one member to the service consumer of any other member. For instance, nationals of one member have moved abroad as tourists, students, or patients to consume the respective services.

Mode 3 - Commercial presence: by a service supplier of one member, through commercial presence, in the territory of any other member. This kind of service is supplied by a locally-established affiliate, subsidiary or representative office of a foreign-owned company. 
Mode 4 - Presence of natural persons: by a service supplier of one member, through the presence of natural persons of a member in the territory of any other member. That means a foreign national provides a service within a member as an independent supplier or employee of a service supplier. (WTO 2008)

However, these four modes do not identify the specific categories of service trade. There were more than 150 kinds of services shown in the documents which were submitted during the trade in service negotiations around the world. According to those documents, the United Nations classifies all services into 11 categories, which are: 1, Transportation; 2, Travel; 3, Communications services; 4, Construction services; 5, Insurance services; 6, Financial services; 7, Computer and Information services; 8, Royalties and license fees; 9, Other business services; 10, Personal, culture, recreational services; and 11, and Government services not informed elsewhere.

The calculation about trade in services was based on these 11 categories in this research. The schedules of specific commitments on trade in services nearly covered all the 11 categories except government services in China-New Zealand FTA.

Since 1960s, services are the fastest growing sector in the global economy. The output of services accounts for two thirds of global output and trade in services accounts for $1 / 5$ of the global trade. The proportion of services to GDP value is higher than $70 \%$ for developed countries, and the number has grown to $50 \%$ for developing countries. Accompanied by the fast development of services, the trade in services increases quickly too. Between 1980 
and 2007, the total export of trade in services grew to 2777.9 billion US dollars from 365 billion US dollars (WTO 2008), increased 7.6 times. In view of the importance of trade in services, China-New Zealand FTA aims to reduce barriers to trade in services and increase the cooperation in this area.

\subsubsection{Status Quo Trade in Services: China, New Zealand and Australia}

China has complied with the commitment of opening service markets step by step after joining the WTO in 2001. In 2007, the service export of China was 121.65 billion US dollars which had increased by $33.1 \%$ compared to 2006 . In the same year, the service import of China was 129.26 billion US dollars with a growth rate of $28.8 \%$ compared to 2006. The deficit of trade in services was 7.61 billion US dollars which was much lower than before 2007. (MOFCOM 2008) China is the only developing country in the top ten large countries on trade in services. However, the statistical standard is just the total value of trade in services not the degree of service development. Most of the services of China are still in developing.

The service export structure of China is presented in the following pie chart. As shown in Figure 5, the structure of trade in services in China is unbalanced. Travel, transportation and other business accounted for $31 \%, 26 \%$ and $22 \%$ of the total service export in 2007 . Financial, royalties and license fees were the weakest points and only accounted for $0.19 \%$ and $0.28 \%$ of total service exports in the same year. 


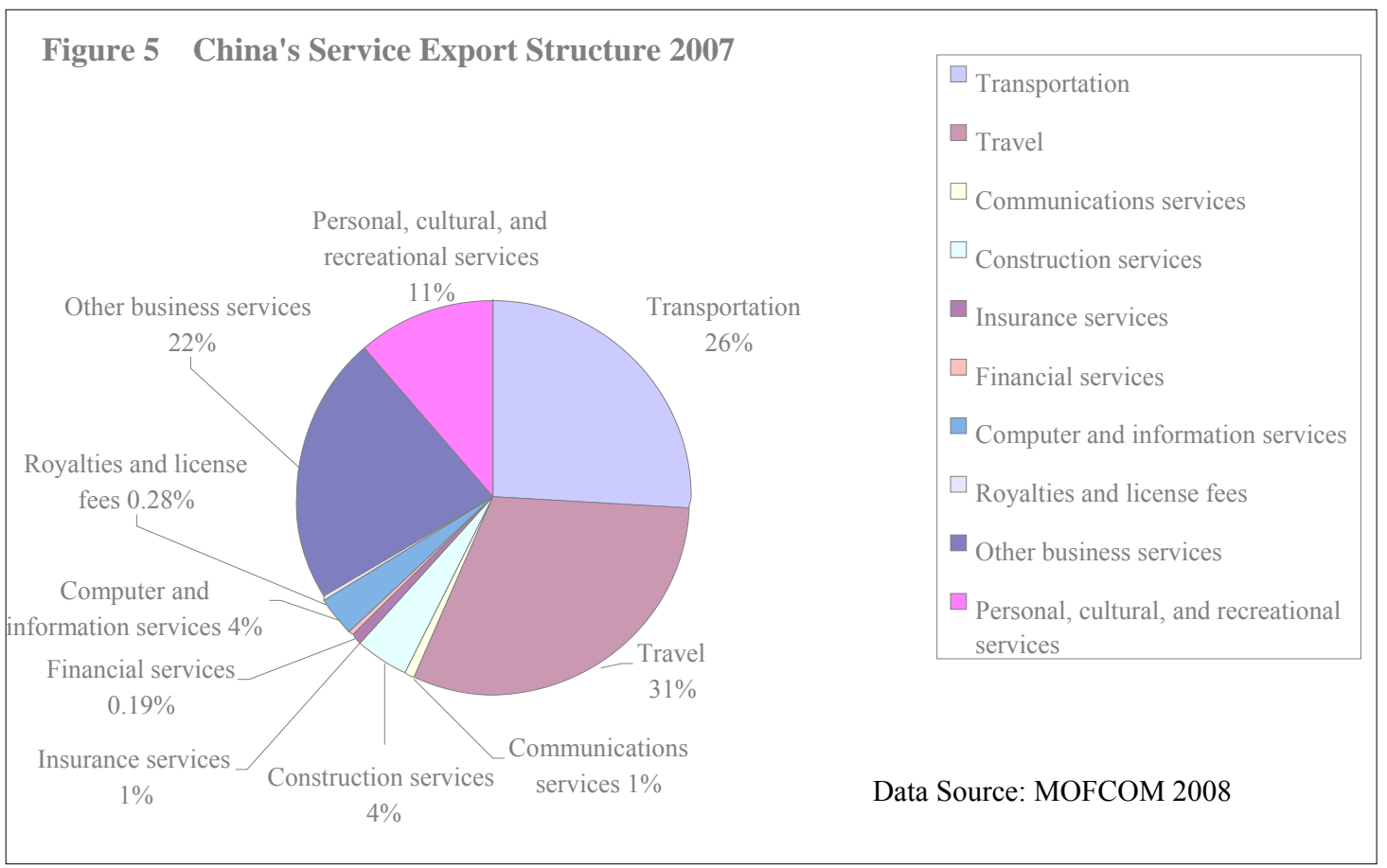

New Zealand's service industry is considerably advanced. The output of services accounts for two thirds of New Zealand's GDP value. The service export of New Zealand was 9.3 billion US dollars and the import was 9.05 billion US dollars in 2007 (OECD 2008). The service export structure of New Zealand in 2007 is depicted in Figure 6. The sectors which contributed the most to economic growth are travel, transportation and other business. These three categories accounted for $59 \%, 22 \%$ and $10 \%$ of the total service export of New Zealand in 2007. Education exports are the fastest growing part and are listed under the travel sector. Moreover, China was the largest export destination for New Zealand in the travel category. In 2007 international students in New Zealand from China reached more than 40 million and tourists from China more than 68.3 million (WTO 2008). 


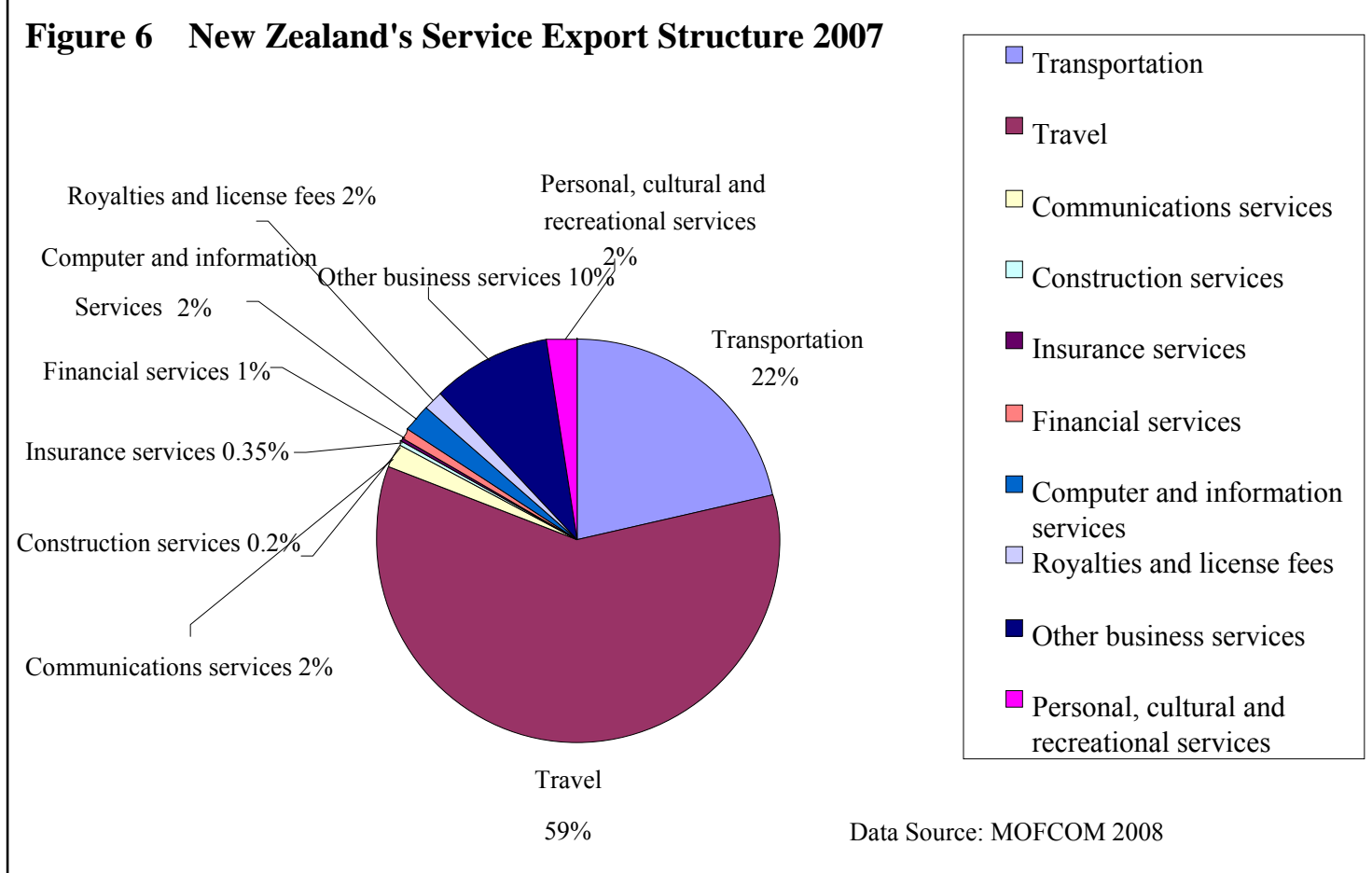

Service is already the pillar industry for Australia. The output of services accounts for $80 \%$ of the total GDP value of Australia. In 2007, trade in services reached 77.926 billion US dollars with a surplus of 1.525 billion US dollars (WTO 2008). In the same year, trade in services accounted for $20.7 \%$ of the total trade value (goods and services trade) in Australia. The service export structure of Australia in 2007 is shown in Figure 7. As presented in the pie chart, the largest sectors of service export in 2007 were travel, transportation and other business which accounted for $59 \%, 22 \%$ and $13 \%$ of the total service exports. The proportion of construction services to the total service export was the smallest at only $0.29 \%$. However, construction services are a protected industry with no imports in Australia. 
Figure 7 Australia's Service Export Structure 2007

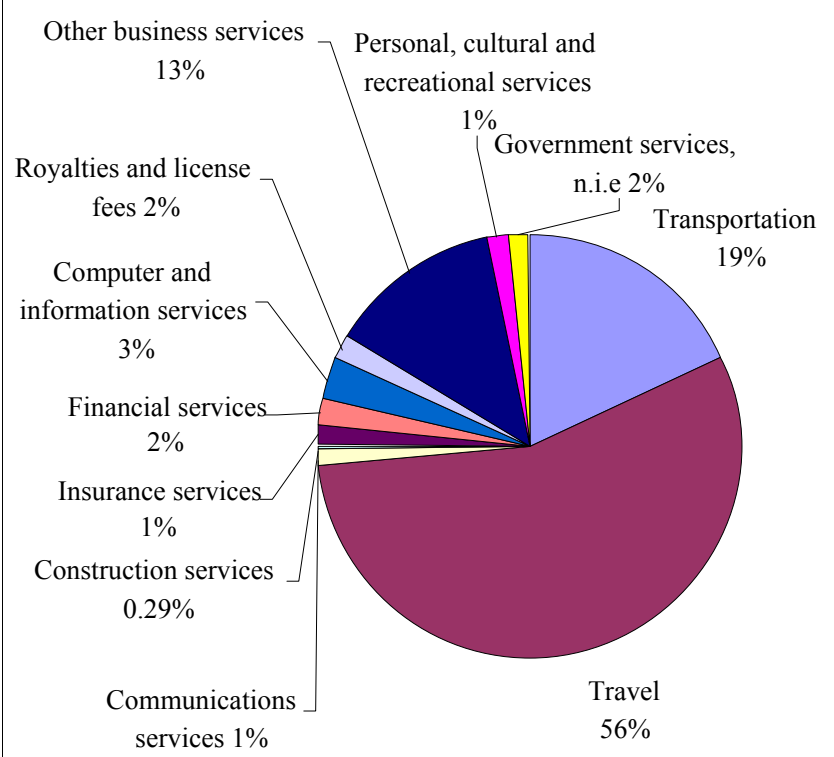

$\square$ Transportation

$\square$ Travel

$\square$ Communications services

$\square$ Construction services

Insurance services

$\square$ Financial services

$\square$ Computer and information services

$\square$ Royalties and license fees

Other business services

$\square$ Personal, cultural and recreational services

$\square$ Government services, n.i.e

\subsubsection{Trade Competitive Power Index (TC)}

In order to compare the service competitive abilities of China, New Zealand and Australia, this research chose Trade Competitive Power Index as an analyzing instrument. The TC index (Peterson and Barras 1987) is an indicator usually used to measure the international competitiveness of trade in services. It measures the proportion of trade balance (surplus or deficit) to the total trade volume. The formula of TC is expressed as follows:

$$
\mathrm{TC}_{\mathrm{i}}=\frac{\mathrm{X}_{\mathrm{i}}-\mathrm{M}_{\mathrm{i}}}{\mathrm{X}_{\mathrm{i}}+\mathrm{M}_{\mathrm{i}} \quad-1 \leq \mathrm{TC}_{\mathrm{i}} \leq 1}
$$

$\mathrm{TC}_{\mathrm{i}}$, Trade Competitive Power Index on $\mathbf{i}$ industry of a country;

$\mathrm{X}_{\mathrm{i}}$, export of $\mathbf{i}$ industry of this country;

$\mathrm{M}_{\mathrm{i}}$, import of $\mathbf{i}$ industry of this country. 
The TC ranges from -1 to 1 . When the value is negative, the competitiveness of this industry is below the average level; on the other hand, when the value is positive, the industry is more competitive than the average level. The average level means the TC value equals 0 . The TC range is separated into several areas representing different meanings: (-1 to -0.6$)$ shows the industry has extremely strong competitive disadvantage; $(-0.6$ to -0.3$)$, shows the industry has relatively strong competitive disadvantage; $(-0.3$ to 0$)$, shows the industry has minor competitive disadvantage; ( 0 to 0.3$)$, shows the industry has minor competitive advantage; ( 0.3 to 0.6$)$, shows the industry has relatively strong competitive advantage; (0.6 to 1$)$ shows the industry has an extremely strong advantage.

The TC indexes of China, New Zealand and Australia on the 11 service categories are presented in Table 16. The calculation is based on formula (2) and the export and import data in Appendixes 10 and 11. Through the TC indexes, the competitiveness of China, New Zealand and Australia on services can be quantified. As indicated in Table 16 the situation for China on trade in services is in deficit but not to an extreme. China is a net importer on services while the total TC index of China is near to 0. China has a minor competitive disadvantage from the perspective of the whole service industry. On the contrary both New Zealand and Australia are net exporters on trade in services with minor competitive advantages overall. 
Table 16 TC Indexes of China, New Zealand and Australia by Services Categories

\begin{tabular}{lllllll}
\hline & China & \multicolumn{3}{c}{ New Zealand } & \multicolumn{3}{c}{ Australia } \\
\hline & $\mathbf{2 0 0 5}$ & $\mathbf{2 0 0 6}$ & $\mathbf{2 0 0 5}$ & $\mathbf{2 0 0 6}$ & $\mathbf{2 0 0 5}$ & $\mathbf{2 0 0 6}$ \\
\hline Total services & -0.059 & -0.046 & 0.005 & 0.006 & 0.009 & 0.013 \\
Transportation & -0.297 & -0.241 & -0.259 & -0.219 & -0.271 & -0.281 \\
Travel & 0.148 & 0.165 & 0.293 & 0.287 & 0.200 & 0.209 \\
Communications services & -0.109 & -0.966 & -0.049 & -0.127 & 0.000 & 0.001 \\
Construction services & 0.231 & 0.565 & 0.317 & -0.433 & 1.000 & 1.000 \\
Insurance services & -0.858 & -0.883 & -0.796 & -0.776 & -0.121 & -0.122 \\
Financial services & -0.047 & -0.720 & -0.181 & 0.034 & 0.303 & 0.252 \\
Computer and information services & 0.063 & 0.260 & -0.130 & -0.197 & 0.050 & 0.063 \\
Royalties and license fees & -0.943 & -0.940 & -0.713 & -0.595 & -0.568 & -0.563 \\
Other business services & 0.177 & 0.169 & -0.172 & -0.200 & 0.139 & 0.174 \\
Personal, cultural, and recreational services & -0.069 & 0.061 & 0.596 & 0.577 & -0.277 & -0.258 \\
Government services, n.i.e & -0.115 & 0.067 & -0.003 & -0.009 & 0.058 & 0.024 \\
\hline
\end{tabular}

Data source: United Nations Conference on Trade and Development, 2008.

Among all 11 categories in which China has a positive TC index in both 2005 and 2006 are travel, construction services, computer and information services and other business services. New Zealand has only two categories with positive TC indexes in both years, travel and personal and cultural and recreation services. Australia is in a better situation with 7 categories with positive TC indexes. They are travel, communications services, construction services, financial services, computer and information services, other business services and government services.

China, New Zealand and Australia all have competitive advantages on travel, but New Zealand has the highest. The travel resources of different countries are not comparable. Because of the particularity of travel and the reduction of trade barriers, the trade on travel will be prosperous after the FTAs are established. However, there may be slight competition on the sector of education exports between New Zealand and Australia. 
Australia has an extremely strong competitive advantage on construction services with a TC number of 1 . The condition of construction services for New Zealand is unstable because there is a big fall in TC indexes from relatively strong competitive advantage to relatively strong competitive disadvantage in 2006. China's TC index on construction services improved inform 2005 to 2006 and is now a relatively strong competitive advantage coming mainly from the abundant low cost labour resources. China faces strong competition from Australia on construction services.

China made a big forward step on computer and information services in 2006 with the TC indexes increasing from 0.064 to 0.260 . These TC numbers are much higher than Australia, not to mention New Zealand, which has a negative TC index. However, it should be noticed that the advantage of China on this area is mainly due to the policy monopoly and outsourcing of services. ${ }^{12}$ When the FTAs come into force, China will need to transfer this monopolistic advantage into a competitive advantage to maintain the better status it has at present.

China, New Zealand and Australia all have negative TC indexes on transportation, insurance and royalties and license fees. Although all three countries are net importers on insurance and royalties and license fees, the differences between China and its developed partners is still apparent. The status for China on these two areas is extremely strong

\footnotetext{
${ }^{12}$ Outsourcing services is subcontracting a progress to a third-party company in order to reduce cost. The development of this form is based on the progress of IT technology.
} 
competitive disadvantages with the TC indexes nearly equalled to -1 . China will suffer negative impacts on insurance and royalties and license fees after the North-South FTAs come into force. There will also be fierce competition among China, New Zealand and Australia on transportation because the TC indexes are very close. Since the 1980s, ocean-going container ships have been dominant and transportation has become a capital and technology intensive service from a labour intensive service. In this case the competition on transportation among China, New Zealand and Australia will be competition on capital and technology.

However, the most worrying area for China is financial services. The TC numbers on financial services fall greatly from -0.047 to -0.720 in 2006 when China fully opened its banking market in the same year. In 2006, the export of financial services remained at the same level but the imports increased 51 times compared to 2005 (MOFCOM, 2007). On the other hand New Zealand made a great forward step on financial services in 2006. The TC indexes of New Zealand on financial services increased from -0.181 to 0.034 . Meanwhile, Australia maintained stability with TC indexes of 0.3 for both years. The North-South FTAs are a big challenge for China on financial services especially as the at present China's financial system remains defective.

The communication services sector is still in danger in China. At the end of 2005, to fulfil the commitments in the WTO, China permitted foreign express enterprises to enter into the service market in China. That resulted in a big fall in the TC index of communications services from -0.109 to -0.966 in 2006 . Australia and New Zealand are doing much better 
than China in this sector. However, the main rivals of Australia and New Zealand are the communications tycoons from other developed countries such as the United States and Japan, not China.

Although according to Table 16 Australia is doing much better than New Zealand on most of the service categories, New Zealand has entered into China's service market much earlier than Australia. This early entry is a great chance to occupy the huge service market of China by New Zealand companies. The difficulty for China is to change the advantages from policy monopolistic or low labour cost into competitive advantages from the industries themselves in order to compete with this greater competition.

\subsubsection{Investment Creation among China, New Zealand and Australia}

Investment is a key aspect of the development of an economy and therefore promoting investment is a main objective of regional integration. The logic between investment and regional integration is simple. Market integration and improvements in the governments' reputation are caused by regional integration stimulating investment in the free trade area. (SUN 2007) Furthermore, investment increases output in two ways: firstly, by enhancing capital-intensive production directly; and secondly by encouraging technology progress, an indirect way to increase output.

Normally an FTA creates two effects on investment, the Investment Creation Effect and the Investment Diversion Effect (Dunning 1998). The establishment of the FTA will eliminate the investment barriers between members. A more transparent, stable investment 
environment and a better rate of return will not only stimulate investment in a particular area but also attract more investment from the outside world. This shift is investment creation. Members of the FTA will promote investment inside the FTA area in order to achieve the economy of scale and satisfy the increasing demand. Because members of the FTA keep the original tariff barriers on other countries separately, the free trade area leads to an indirect trade discrimination against other countries. For the sake of avoiding trade barriers and potential loss, non-member countries will increase the foreign direct investment in the free trade area. The Investment Diversion Effect suggests the capital flow between members will increase because of the production restructuring and resource reallocation and that members and non-members will also be more likely to search for a better place to increase investment in the FTA area to take advantage of a better rate of return.

\subsubsection{Investment status quo among China, New Zealand and Australia}

New Zealand is a free market economy with traditional capital inflow. The stock of foreign direct investment (FDI) in New Zealand was 67.1 billion US dollars until March 2008 (MOFCOM 2008). Investment from Australia accounted for $52 \%$ of the total FDI which

New Zealand attracted. In recent years China has increased FDI in New Zealand. At the end of 2007, the stock of non-financial direct investment from China to New Zealand was 4.106 million US dollars. This investment from China mainly covers resource, transportation, insurance, trade in goods and real estate sectors. At the same time New Zealand encourages investment in China as well. New Zealand has constructed 1223 investment projects with an actual investment stock of 720 million US dollars in China to 
the end of 2007 (MOFCOM 2008). Those investment projects are mostly in the sectors, manufacturing, real estate, agriculture, forestry, fishery, charter business, construction, transportation and cultural recreation.

According to the analysis above in dynamic effect of trade in goods and services, New Zealand has extremely strong competitiveness on forestry and cattle husbandry, also the main export sectors to China. However, the utilization of foreign capital on the sectors of forestry and cattle husbandry only accounted for $1.23 \%$ of the total utilization of foreign capital for China in 2007 (MOFCOM 2008). Therefore, there is a lot of potential for investment in forestry and cattle husbandry sectors in China for New Zealand investors.

China encourages all kinds of enterprises in China, ${ }^{13}$ to invest abroad and develop transnational business. From 2002 to 2007 the average growth rate of non-financial outward foreign direct investment of China was $56 \% .{ }^{14}$ In addition China's outward investment flows achieved 26.51 billion US dollars in 2007, the highest record in history. The situation of China's outward FDI to Australia and New Zealand in recent years is presented in Table 17 and Table 18, from the perspectives of investment flow and investment stocks.

\footnotetext{
${ }^{13}$ Both privately owned or government owned and controlled.

${ }^{14}$ Calculated according to the data from "2007 Statistical Bulletin of China's Outward Foreign Direct Investment", October 30,2008.
} 
Table 17 China's Outward fDi flows to Australia and New Zealand

2003-2007 Unit: million US dollars

\begin{tabular}{llllll}
\hline Country & 2003 & 2004 & 2005 & 2006 & 2007 \\
\hline Australia & 3.039 & 12.495 & 19.307 & 8.76 & 53.159 \\
New Zealand & 0.307 & -0.49 & 0.347 & 0.349 & -0.16 \\
\hline
\end{tabular}

Adapted from MOFCOM 2008

Table 18 China's Outward fDi Stocks to Australia And New Zealand

Unit: million US dollars

\begin{tabular}{lllll}
\hline Country & 2004 end & 2005 end & 2006 end & 2007 end \\
\hline Australia & 49.458 & 58.746 & 79.435 & 144.401 \\
New Zealand & 3.322 & 3.518 & 5.127 & 5.117 \\
\hline
\end{tabular}

Adapted from MOFCOM 2008

As indicated in the two tables above, investment in Australia from China increased steadily during the five years and there was a leap in 2007 with a growth rate of 507\% compared to 2006. At the end of 2007 Australia was the fifth largest country to attract China's outward FDI. On the contrary the investment from China to New Zealand fluctuated heavily and even showed negative growth in 2004 and 2006. The situation for the stock of China's outward FDI in New Zealand improved a lot in 2006 but was reduced in 2007.

The limited domestic market of New Zealand is the constraint of attracting more FDI from China compared to other countries. However, the potential of resource sectors in New Zealand should also be noticed. Considering the investment creation effect of regional integration, there will be a double win situation for both China and New Zealand after the China-New Zealand FTA comes into force. The stimulation of investment will give companies from both sides the confidence to increase investment in each others' markets. Investment in New Zealand will help China obtain new business growth opportunities and 
FDI from China will give the economy of New Zealand stimulation. On the other hand, investment from New Zealand to China will bring New Zealand's advanced technology and administration experience to China.

The volume of FDI from China to Australia is much bigger and most of the FDI is concentrated in the mining industry. Investment in the mining sector from China to Australia accounted for 45.5\% of the total FDI in year 2007 (MOFCOM 2008). The main type of Chinese investment in Australia is resource exploitation (ferrous metal and non-ferrous metal). This kind of investment in resource area aims to compensate for the domestic resource shortage in China. This is a way to guarantee the long term economic development and resource security for Chinese sustainable development policy.

If the demand of resources is merely satisfied by imports, there will be two negative consequences. Firstly, the resource supply will be cut off by the exporters because resource trade is easily affected by international political relations or temporary policies from the exporting countries. Secondly, there may be continually increasing prices. Considering that scarcity of resources and demand of resources are usually nonflexible, the price of resources will increase sharply every year.

The best example of this is the price of ores which increased by $38.44 \%$ per annum during the last 6 years in the Asia area. The growth rate of the price of iron ores even achieved $82.06 \%$ in 2008 compared to year 2007 . The product with the highest growth rate $(96.5 \%)$ was block mine from Australia's mine tycoons, Rio Tinto and BHP (China United Steel 
2009). China is the biggest buyer of Australia's mining resources, which means China will be hurt the most by the inflation of mining resource prices. As a result, investment in the resource sector is the best way for China to avoid uncertainties in resource trading. In addition this could also bring benefits from exporting equipment and labour.

In these North-South FTAs, the investment creation effect has special features. From the perspective of the southern country, the FDI from the northern country brings technology which comes in with the investment. This situation is called Technology Spillover (Kokko 1994). However, when the southern country increases the FDI to the northern country, this is also a good channel for absorbing local technology and administrative experience. Furthermore, the control of skills could also be used to promote the industry upgrading in the domestic market of the southern country.

\subsection{Summary of the Traditional Gains}

Analysis of the static effect shows that the trade creation effect is dominant in the North-South FTA. The analysis of the dynamic effect gives details of the competitive situation of trade in goods, trade in services and the investment creation among China, New Zealand and Australia. The dynamic effect improves the industry structures from two aspects for both the northern and the southern countries. Initially, market integration increases the trade volume between members which then reinforces the competitiveness of the strong industries for both developing and developed countries.

New Zealand and Australia will benefit from the economy of scale effect by occupying the Chinese market. The economy of scale effect is not easily obtained in their own limited 
domestic markets. Moreover, the virtue of the economy of scale effect is the reduction of the long-term average cost of production which could reinforce the competitiveness of their products. The economy of scale effect also brings the enlarged transnational companies bargaining power with respect to the third party and greater access to industry information. These virtues of the economy of scale give New Zealand and Australia the initiative in industries such as cattle husbandry, forestry or mining in the market of China.

For China, despite the fact that China will not observe the economy of scale effect in the northern markets, it is still a good opportunity to develop transnational business. China will benefit from absorbing local technology and advanced administrative experience of the northern markets. Entry of advanced companies from New Zealand and Australia in the service market of the Chinese economy will stimulate further development of Chinese services.

Secondly, fierce competition will act as an engine to stimulate the development of the protected vulnerable industries, especially for the southern country. After the initial negative impact and painful adjustment, the vulnerable industries will possess the technology and improve production efficiency to survive the newly introduced competition. This improvement in production efficiency may take a much longer time for the protected industries without the external stimulus of the North-South FTAs. The affected vulnerable industries in China are agriculture, cattle husbandry and the service sector of China. 
Another positive impact of the North-South FTAs for China is that the enlarged import volume from developed countries will help China to enhance its influence on formulating the international trade rules. One of the important elements of influencing international trade rules is how big an import market the country can provide to the world (SU 2006). As this grows with the North-south FTAs, Chinese influence on setting the international trade rules should also grow.

Clearly, the traditional impacts of the North-South FTAs for China, New Zealand and Australia are significant when analysing the static effect and the dynamic effect. The next chapter moves away from analysis of these traditional gains to an analysis of the economic impact of the China-New Zealand FTA and the proposed China-Australia FTA in terms of non-traditional gains. This analysis provides a more encompassing view of the impact of these North-South FTAs on the economies of China, New Zealand and Australia and the RTA area created by the agreements. 


\section{Non-traditional Gains of the China-New Zealand FTA and the China-Australia FTA}

Non-traditional gains are the benefits which derive from regional integration policies. This research focuses on the regional trade agreements (RTAs) strategies of China, New Zealand and Australia. This chapter looks at how each country intends to build its own Hub \& Spoke system but it is drawn into the RTA web. Separate analysis of China, New Zealand and Australia's RTA strategies will be completed before moving on to look at the Insurance Effect of the China-New Zealand FTA and the proposed China-Australia FTA. The chapter will conclude by discussing the meaning of the two FTAs.

\subsection{The Hub \& Spoke System}

Since the 1980s the quantity of bilateral FTAs has surged. As a result an overlapping web of FTAs has created an RTA web. The country in the RTA web that signs agreements with more than two partners becomes the centre of the hub and its partners the spoke countries (Figure 4). In the original Hub \& Spoke system the spoke countries do not sign RTAs with each other (Wonnacott 1996).

The Hub \& Spoke system has different effects on the hub country and the spoke countries. From the perspective of the hub country, the advantages of the hub \& spoke system are threefold. Firstly, the hub country gains market access. The hub country has preference to enter all the spoke countries' markets. That is to say the hub country expands its available market several times. On the other hand, all the spoke countries' products crowd into the hub country's limited market and compete with each other to occupy a slice of the share. 
This competition causes a decrease in prices and an increase in the range of products available to consumers, which increases the surplus of consumers in the hub country.

Secondly, the hub country benefits from industry agglomeration. The Hub \& Spoke system gives the hub country inherent location advantages. The hub country's free access to all the spoke countries' markets attracts direct investment from both inside and outside the country. The hub country will become an economically active centre and gradually benefit from industry agglomeration.

Lastly, the hub country gains from increased bargaining power. The initiative in negotiation of the hub country with respect to a third-party increases along with the formation of the hub \& spoke system. The Hub \& Spoke system also promotes the status of the hub country in the world's multilateral trade system.

From the perspective of the spoke country, the disadvantages of the hub \& spoke system are threefold. Firstly, there is the problem of trade diversion. The trade between the spoke country and a non-system country could be replaced by the new trade between the spoke country and the hub country. The trade between spoke countries could also decrease because of the preferential trade agreements between the hub country and the spoke countries respectively.

Secondly, there is also a problem of trade discrimination. The spoke countries do not have any RTAs with each other. That is to say, compared to the products from the hub country, all the other products from the spoke countries are discriminated on the spoke countries' 
markets. Finally, there is a problem of the location disadvantage. The spoke country is in the situation of inferiority and could not attract more FDI compared to the hub country. Furthermore the spoke country is in the danger of suffering the investment diversion.

As a result, the spoke country's benefit is so limited in the hub \& spoke system. In other words, the income of the hub country is established at the loss of the spoke countries' income (Wonnacott 1996). However, even though the benefit to the spoke country is much lower than the hub country's, it is still a better situation for the spoke country to join in the system than stand outside. This is because the country which refuses to join in the hub \& spoke system faces the situation of fewer potential trade partners and more and more serious trade discrimination. Consequently, the spoke country has to accept the strict terms to join in the hub \& spoke system. However, the positive points for the spoke country are the hub country's market access and the direct investment from the hub country. The advanced technology which comes along with the hub country's FDI improves the spoke country's production efficiency. The hub \& spoke system could also narrow the income gap between the hub country and the spoke country.

\subsection{Comparison of RTA Strategies among China, Australia and New Zealand}

As indicated above, the dominant position and the advantages of the hub country is extremely important in the hub \& spoke system. In this case, most countries actively participate in the new round of signing RTAs. In addition, every country competes to be 
the hub country. This is also the case for the countries China, New Zealand and Australia in their RTAs. Each country is competing to maximise the benefits to themselves of the RTAs they enter into.

\subsubsection{The RTA Strategy of China}

China began its RTA plan late but has made rapid progress. From 2001 until now, China has already signed RTAs with 29 countries or regions and established 12 regional trade integration areas. The distribution of the 29 countries encompasses Asia, Oceania, Latin America, Europe and Africa. The trade volume in the 12 regional trade integration areas accounted for $1 / 4$ of China's total trade in 2007 (MOFCOM 2008). The situation of China's RTAs system is presented in Table 19 on the next page. 
Table 19 China's Regional Integration Agreements

\begin{tabular}{|c|c|c|}
\hline Members & Agreements & Stage in Processes \\
\hline \multicolumn{3}{|l|}{ Agreements in force } \\
\hline $\begin{array}{l}\text { Shanghai } \\
\text { Cooperation } \\
\text { Organization } \\
(\mathrm{SCO})^{15}\end{array}$ & $\begin{array}{l}\text { Declaration of Shanghai Cooperation } \\
\text { Organization }\end{array}$ & Entered into force in June 2001 \\
\hline \multirow[t]{2}{*}{ China-ASEAN $^{16}$} & $\begin{array}{l}\text { Agreement on Trade in Goods of the } \\
\text { Framework Agreement on Comprehensive } \\
\text { Economic Cooperation Between China and } \\
\text { ASEAN }\end{array}$ & Entered into force in July 2005 \\
\hline & $\begin{array}{l}\text { Agreement on Trade in Services of the Frame } \\
\text { work Agreement on Comprehensive Economic } \\
\text { Cooperation Between China and ASEAN }\end{array}$ & Entered into force in July 2007 \\
\hline $\begin{array}{l}\text { Mainland } \\
\text { China-Hong Kong } \\
\text { and Macau }\end{array}$ & $\begin{array}{l}\text { Closer Economic Partner Arrangement Between } \\
\text { Mainland China and Hong Kong, Macau }\end{array}$ & $\begin{array}{l}\text { Entered into force in January } \\
2006\end{array}$ \\
\hline $\begin{array}{l}\text { China-India, Laos, } \\
\text { Bangladesh, } \\
\text { Republic of Korea, } \\
\text { Sri Lanka }\end{array}$ & Asia-Pacific Trade Agreement & $\begin{array}{l}\text { Entered into force in September } \\
2006\end{array}$ \\
\hline \multirow[b]{2}{*}{ China- Chile } & $\begin{array}{l}\text { Free Trade Agreement Between China and } \\
\text { Chile (Trade in Goods) }\end{array}$ & $\begin{array}{l}\text { Entered into force in October } \\
2006\end{array}$ \\
\hline & $\begin{array}{l}\text { The Supplementary Agreement on Trade in } \\
\text { Services of Free Trade Agreement Between } \\
\text { China and Chile }\end{array}$ & Signed in April 2008 \\
\hline \multirow{3}{*}{ China-Pakistan } & $\begin{array}{l}\text { Agreement on The Early Harvest Program For } \\
\text { The Free Trade Agreement Between China and } \\
\text { Pakistan }\end{array}$ & Signed in April 2005 \\
\hline & $\begin{array}{l}\text { Agreement on Trade in Goods Between China } \\
\text { and Pakistan }\end{array}$ & Entered into force July 2007 \\
\hline & $\begin{array}{l}\text { Agreement on Trade in Services Between China } \\
\text { and Pakistan }\end{array}$ & Signed in February 2009 \\
\hline China-New Zealand & $\begin{array}{l}\text { Free Trade Agreement Between China and New } \\
\text { Zealand }\end{array}$ & $\begin{array}{l}\text { Entered into force in October } \\
2008\end{array}$ \\
\hline China-Singapore & $\begin{array}{l}\text { Free Trade Agreement Between China and } \\
\text { Singapore }\end{array}$ & $\begin{array}{l}\text { Entered into force in January } \\
2009 \text { by Singapore; China will }\end{array}$ \\
\hline
\end{tabular}

\footnotetext{
${ }^{15}$ SCO has six members and four observers. The six members are China, Kazakhstan, Kyrgyz, Tajikistan, Russian and Uzbekistan. The four observers are India, Iran, Pakistan and Mongolia. SCO is a regional integration agreement and it seeks for economic cooperation lately.

${ }^{16}$ ASEAN (Association of Southeast Asian Nations) was established in 1967. ASEAN includes 10 members: Brunei Darussalam, Cambodia, Indonesia, Lao, Malaysia, Myanmar, Philippines, Singapore, Thailand and Viet Nam.
} 


\begin{tabular}{|c|c|c|}
\hline & & enter into force in January 2010 \\
\hline \multicolumn{3}{|c|}{ Agreements under negotiation } \\
\hline China-GCC ${ }^{17}$ & Free Trade Agreement Between China and GCC & $\begin{array}{l}\text { Both sides have reached an } \\
\text { agreement on trade in goods. }\end{array}$ \\
\hline China-Australia & $\begin{array}{l}\text { Free Trade Agreement Between China and } \\
\text { Australia }\end{array}$ & $\begin{array}{l}\text { Report on round 13, } \\
\text { December } 2008\end{array}$ \\
\hline China-Iceland & $\begin{array}{l}\text { Free Trade Agreement Between China and } \\
\text { Iceland }\end{array}$ & Report on round 4, April 2008 \\
\hline China-Peru & Free Trade Agreement Between China and Peru & $\begin{array}{l}\text { Report on round 7, November } \\
2008\end{array}$ \\
\hline China- Norway & $\begin{array}{l}\text { Free Trade Agreement Between China and } \\
\text { Norway }\end{array}$ & Report on round 3, March 2009 \\
\hline China-SACU ${ }^{18}$ & $\begin{array}{l}\text { Free Trade Agreement Between China and } \\
\text { SACU }\end{array}$ & $\begin{array}{l}\text { Announced the launch of } \\
\text { negotiation in June } 2004\end{array}$ \\
\hline China-Costa Rica & $\begin{array}{l}\text { Free Trade Agreement Between China and } \\
\text { Costa Rica }\end{array}$ & $\begin{array}{l}\text { Announced the launch of } \\
\text { negotiation in November } 2008\end{array}$ \\
\hline \multicolumn{3}{|c|}{ Agreements under study } \\
\hline China-India & $\begin{array}{l}\text { Regional Trade Arrangement Between China } \\
\text { and India }\end{array}$ & Finished the feasibility study \\
\hline China-South Korea & $\begin{array}{l}\text { Free Trade Agreement Between China and } \\
\text { South Korea }\end{array}$ & $\begin{array}{l}\text { Finished 5th joint study in June } \\
2008\end{array}$ \\
\hline
\end{tabular}

As shown in Table 19, the partners of China's RTAs are mostly the surrounding countries of China. The balance of the distribution of the partners among continents is another consideration for China. There are three overriding considerations that drive China's RTAs strategy: the requirement of diplomacy with its surrounding neighbours; the establishment of long term and reliable energy and resource supply relationships, and coordination of the 'Go Out' strategy. Each of these considerations is discussed below in more detail.

\footnotetext{
${ }^{17}$ The GCC (Cooperation Council for the Arab States of the Gulf) was established in 1981 and has six members. They are Bahrain, Kuwait, Oman, Saudi Arabia and United Arab Emirates. GCC is the one of the fastest growing economies and mostly due to a boom in oil and natural gas revenues. The detected petroleum and natural gas reserves account for $45 \%$ and $23 \%$ of the world's total reserves.

${ }^{18}$ SACU (South Africa Customs Union) has five members. They are Botswana, Lesotho, Namibia, South Africa and Swaziland. The SACU was established in 1969. The GDP and trade of South Africa account for more than $90 \%$ of the total values of SACU.
} 


\subsubsection{The requirement of diplomacy with important surrounding neighbours}

Since China joined into the WTO and became more actively integrated into the global production system in 2001, the most important requirement for the development of China has been seen as peaceful and stable international circumstances. However, Asia is an unstable continent with a history of disputes for many reasons including historical grievances, religious tension and the remnant problem of war. At the same time, Asia is the area of the world with the most economic vitality. This economic vitality is dependent on maintaining a stable political situation in the region.

China pursued the diplomacy of a great power focusing on the international relationship with the United States after the beginning of the policies of reform and opening. Following this strategy provided China with a good international environment to develop in during the two decades after $1978 .{ }^{19}$ However, the rise in the economic strength of the European Union and Japan led to a relative decline of the economic strength of the United States in the global multilateral trade system. This, accompanied by the great economic development of China, has led to Asian neighbour countries showing more wariness towards China in the last decade. This caution comes mainly from Japan and Russia which are both great economic powers and the great military powers. Since the global economic and political balances begun changing China begun to pursue greater diplomacy with its surrounding neighbours in the early years of this century.

${ }^{19} 1978$ is the time when China started the reform and opening-up policy. 
China is seen as a great power in the Asia-Pacific region both economically and politically. It is therefore important for China to take more responsibility to maintain the peace and the stability of the Asia-Pacific region. China is surrounded by 29 countries and 15 of them share one section of the state boundary line with China. The other 14 neighbours are adjacent to China with the ocean separating the territories. In addition, the trade between China and all the other Asian countries accounted for $53.32 \%$ of China's total trade in $2008 .^{20}$ In that case, a friendly neighbouring environment is not only necessary for China's further economic development but also crucial for China's territorial security. As a result, signing institutional RTAs with surrounding neighbours is a key element of the diplomacy with China's surrounding neighbours.

The South-South FTA between China and ASEAN is one of the earliest RTAs that China signed. Choosing ASEAN as China's RTA partner is not only due to its economic activity and successful experience on South-South cooperation but also for the reason of its important geographic location. Firstly, ASEAN is near to the coastal provinces of China, an important component of China's surrounding neighbours. Secondly, ASEAN as a whole is located between the Pacific Ocean and Indian Ocean. It is the only channel for China's shipping to the other continents. Consequently, signing the FTA with ASEAN has two positive effects, establishing a stable Southeast Asian environment and constructing a safe shipping channel between China and other continents.

\footnotetext{
${ }^{20}$ The data was calculated based on the data from MOFCOM 2008. The total trade of China in 2008 is 2561.63 billion US dollars. The trade between China and Asia in 2008 is 1365.952 billion US dollars.
} 
Another geographically important RTA for China is the Shanghai Cooperation Organisation (SCO) which is also the first RTA China signed. China initiated and helped to bring about the SCO. This RTA is crucial for the border security of China. This is because the territories of the members of the SCO are adjacent to China's border in the whole north and west. The border of China in the north and the west are mainly minority ethnic provinces such as Xinjiang, Tibet and Inner Mongolia. Another geographic consideration is that most of the SCO members are located in Central Asia. They are the bridges for China to connect Asia and Europe. The SCO focuses more on cooperation in security and anti-terrorism but it has started to focus more on economic development as well.

Signing RTAs with China's neighbour countries is a means to enhance diplomacy with important surrounding neighbours. It is also a good way to create greater opportunity for common development with neighbouring countries and to make them benefit from China's great economic growth. Diplomacy is an important consideration that drives China's RTA strategy in China's surrounding areas.

\subsubsection{Establishing long-term and reliable energy and resource supply relationships}

The unbalance of supply and demand on energy and resources is increasingly prominent throughout the whole world. As a big developing country, this problem is particularly acute for China. In 2007, China's global proportion of coal consumption was $41.27 \%$ and for natural gas consumption $2.30 \%$. China's oil consumption accounted for $9.31 \%$ of the 
total oil consumption of the world and hydroelectricity consumption was $15.4 \% .{ }^{21}$ The iron ore imports of China during the five years between 2002 and 2007 was 1.34 billion tons accounting for $42 \%$ of the total iron ore amount of the global maritime transportation (China United Steel 2009).

The huge demand of China for energy and resources influences the relationship between demand and supply in the world energy and resource markets. As a huge buyer on the energy and resource markets, China's influence on pricing is excessively passive. There are two reasons for this situation. Firstly, China's growing demand for energy and resources are non-negotiable (they are required for development) and this pushes prices up especially when the supply market is irreplaceable. An example is Australia's iron ore. Although India and Brazil are also big iron ore suppliers, considering the quality of iron ore and the shipping cost, Australia is preferred by China. Secondly, China's companies as the buyers have not formed an alliance to seize the initiative in price negotiation.

Signing institutional RTAs with the energy or resource-exporting countries can provide security on energy and resource supply for China. The stable relationship with supply countries could also help China to improve the pricing power. Meanwhile, the RTA web can diversify the energy and resource supply channels. For example, China now trades in Central Asia for petrol and natural gas, in ASEAN for forestry and minerals, and with the GCC for oil, as well as with Australia for iron ore and Chile for copper ore. An important

\footnotetext{
${ }^{21}$ The data was calculated based on the data of BP Statistical Review of World Energy 2008.
} 
consideration for China when conducting RTA negotiation is therefore ensuring long term stable markets for resources necessary for China's economic development.

\subsubsection{Coordinating the "Going Out" strategy}

Accompanying increased exports from China is a surge in disputes targeting China. Under the WTO system, tariff barriers are extremely restricted. As a result, over the last decade other protective measures have been launched more frequently. These trade protectionist measures include technical barriers to trade and increasingly have been subject to trade remedy investigations. ${ }^{22}$ China has been at the top of the list of countries subject to anti-dumping investigations for 12 years. The situation for exports from China has been getting more and more difficult in recent years. In 2008, export products of China were subjected to 93 trade remedy investigations from 21 countries. Among the 93 trade remedy investigations 70 involved anti-dumping investigations, 11 anti-subsidy investigations and the rest investigations into safeguard measures with 2 special safeguard measures (MOFCOM 2009). Products which suffered investigations had to exit the market in question or pay extremely high punitive tariffs. Only the products which won the cases could keep the market after the investigation.

These trade disputes seriously deteriorate the export environment for China. Trade remedy investigations could easily cause a retaliatory trade war between the WTO members. The negative consequence of such a series of trade disputes would be a situation of redundant export products and a shortage of import resources. One of the ways to lesson these

\footnotetext{
${ }^{22}$ Trade remedy investigations generally involve investigations of allegations of dumping, subsidy, safeguards and special safeguard measures.
} 
disputes is direct investment in the export target countries. The Chinese "Going Out" strategy which has been implemented since 1998 encourages all kinds of enterprises to invest overseas and build transnational companies. The strategy also aims to create new foreign markets and international production and marketing systems for Chinese enterprises. Furthermore, signing RTAs with the investment target countries can create a good investment environment for the companies of China. Developing such an RTA strategy can also improve China's situation in trade disputes somewhat because some of the investigations are caused by a dispute over China's market economy status. The premise of signing an RTA with China is that the partner admits the market economy status of China thus taking away the ability to make this dispute.

\subsubsection{The RTA Strategies of Australia and New Zealand}

Australia and New Zealand established the Closer Economic Relations agreement early in 1983. However, both of them did not start their RTA strategies systematically until the beginning of this century. The regional integration agreements of Australia and New Zealand are presented in Table 20 and Table 21 respectively. 
Table 20 Australia's Regional Integration Agreements

\begin{tabular}{|c|c|c|}
\hline Members & Agreements & Stage of progresses \\
\hline \multicolumn{3}{|l|}{ Agreements in force } \\
\hline Australia-New Zealand & $\begin{array}{lcc}\text { Australia-New } & \text { Zealand } & \text { Closer } \\
\text { Economic } & \text { Relations } & \text { Trade } \\
\text { Agreement } & & \\
& & \end{array}$ & Entered into force in January 1983 \\
\hline Australia-Singapore & $\begin{array}{lll}\text { Singapore-Australia } & \text { Free } & \text { Trade } \\
\text { Agreement } & & \\
\end{array}$ & Entered into force in July 2003 \\
\hline Australia-United States & $\begin{array}{l}\text { Australia-United States Free Trade } \\
\text { Agreement }\end{array}$ & Entered into force in January 2005 \\
\hline Australia-Thailand & $\begin{array}{l}\text { Thailand-Australia } \\
\text { Free }\end{array}$ & Entered into force in January 2005 \\
\hline Australia-ASEAN & $\begin{array}{l}\text { Joint Declaration on the } \\
\text { ASEAN-Australia Comprehensive } \\
\text { Partnership }\end{array}$ & $\begin{array}{l}\text { Signed in 2007. Covers political and } \\
\text { security, economic, socio-cultural } \\
\text { and development cooperation. }\end{array}$ \\
\hline Australia-NZ-ASEAN & $\begin{array}{l}\text { ASEAN-Australia-NZ Free Trade } \\
\text { Agreement }\end{array}$ & Signed in February 2009. \\
\hline \multicolumn{3}{|c|}{ Agreements under negotiation } \\
\hline Australia-China & $\begin{array}{l}\text { Australia-China } \\
\text { Free }\end{array}$ & Report on round 13, December 2008 \\
\hline $\mathrm{ACTA}^{23}$ & $\begin{array}{l}\text { Anti-Counterfeiting } \\
\text { Agreement }\end{array}$ & Report on round 4, December 2008 \\
\hline Australia-Malaysia & $\begin{array}{l}\text { Malaysia-Australia } \text { Free } \\
\text { Agreement }\end{array}$ & $\begin{array}{l}\text { Agreed to resume negotiations in } \\
2009\end{array}$ \\
\hline Australia-GCC & $\begin{array}{lll}\text { Australia-GCC } & \text { Free } & \text { Trade } \\
\text { Agreement } & & \\
\end{array}$ & Report on round 3, in February 2009 \\
\hline Australia-Japan & $\begin{array}{lll}\text { Australia-Japan } & \text { Free } & \text { Trade } \\
\text { Agreement } & & \\
\end{array}$ & Report on round 4, in February 2009 \\
\hline $\begin{array}{l}\text { Australia-The Republic } \\
\text { of Korea }\end{array}$ & $\begin{array}{lll}\begin{array}{l}\text { Australia--Korea } \\
\text { Agreement }\end{array} & \text { Free } & \text { Trade } \\
\end{array}$ & Launched negotiations in March 2009 \\
\hline \multicolumn{3}{|l|}{ Agreements under study } \\
\hline Australia-India & $\begin{array}{lll}\text { Australia-India } & \text { FTA } & \text { Feasibility } \\
\text { Study } & & \end{array}$ & $\begin{array}{l}\text { The Joint Study Group met twice in } \\
2008\end{array}$ \\
\hline Australia-Indonesia & $\begin{array}{l}\text { Indonesia-Australia } \\
\text { Feasibility Study }\end{array}$ & Expected to be completed in 2009 \\
\hline
\end{tabular}

${ }^{23}$ The countries or regions involved in ACTA are Australia, Canada, the European Union, Japan, Korea, Mexico, New Zealand, Singapore, Switzerland, the United Arab Emirates and the United States. 
Table 21 New Zealand's Regional Integration Agreements

\begin{tabular}{|c|c|c|}
\hline Countries & Agreements & Stage of progresses \\
\hline \multicolumn{3}{|l|}{ Agreements in force } \\
\hline New Zealand-Australia & $\begin{array}{l}\text { Australia and New Zealand } \\
\text { Closer Economic Relations Trade } \\
\text { Agreement }\end{array}$ & Entered into force in January 1983 \\
\hline New Zealand-Singapore & $\begin{array}{l}\text { Agreement between New } \\
\text { Zealand and Singapore on a } \\
\text { Closer Economic Partnership }\end{array}$ & Entered into force in January 2001 \\
\hline New Zealand-Thailand & $\begin{array}{l}\text { New Zealand-Thailand Closer } \\
\text { Economic Partnership } \\
\text { Agreement }\end{array}$ & Entered into force in July 2005 \\
\hline $\begin{array}{l}\text { New Zealand-Brunei } \\
\text { Darussalam, Chile and } \\
\text { Singapore }\end{array}$ & $\begin{array}{l}\text { Trans-Pacific Strategic Economic } \\
\text { Partnership Agreement }\end{array}$ & $\begin{array}{l}\text { Entered into force in May 2006; } \\
\text { Negotiation on financial services and } \\
\text { investment began in March } 2009 \text { with } \\
\text { the US participating. }\end{array}$ \\
\hline New Zealand-China & $\begin{array}{l}\text { Free Trade agreement between } \\
\text { China and New Zealand }\end{array}$ & Entered into force in October 2008 \\
\hline $\begin{array}{l}\text { New Zealand- } \\
\text { Australia-ASEAN }\end{array}$ & $\begin{array}{l}\text { ASEAN, Australia and New } \\
\text { Zealand Free Trade Agreement }\end{array}$ & Signed in February 2009 \\
\hline \multicolumn{3}{|c|}{ Agreements under negotiation } \\
\hline $\mathrm{ACTA}$ & $\begin{array}{ll}\text { Anti-Counterfeiting } & \text { Trade } \\
\text { Agreement } & \\
\end{array}$ & Report on round 4, December 2008 \\
\hline New Zealand-GCC & $\begin{array}{l}\text { Free Trade Agreement Between } \\
\text { New Zealand and GCC }\end{array}$ & Report on round 4, February 2009 \\
\hline New Zealand-Malaysia & $\begin{array}{l}\text { Free Trade Agreement Between } \\
\text { New Zealand and Malaysia }\end{array}$ & Report on round 8, November 2008 \\
\hline New Zealand-Hong Kong & $\begin{array}{l}\text { Closer Economic Partnership } \\
\text { Between New Zealand and Hong } \\
\text { Kong }\end{array}$ & $\begin{array}{l}\text { Talks were suspended in late } 2002 \\
\text { after five rounds. Preparatory talks } \\
\text { restarted in March } 2009 \text {. }\end{array}$ \\
\hline $\begin{array}{l}\text { New Zealand-The } \\
\text { Republic of Korea }\end{array}$ & $\begin{array}{l}\text { Free Trade Agreement Between } \\
\text { New Zealand and Korea }\end{array}$ & $\begin{array}{l}\text { Announced the launch of negotiation } \\
\text { in March } 2009\end{array}$ \\
\hline \multicolumn{3}{|l|}{ Agreements under study } \\
\hline New Zealand-India & $\begin{array}{l}\text { Free Trade Agreement Between } \\
\text { New Zealand and India }\end{array}$ & Finished the joint study \\
\hline New Zealand-Japan & $\begin{array}{l}\text { New Zealand-Japan Joint } \\
\text { Economic Consultations }\end{array}$ & Established working groups in 2006 \\
\hline
\end{tabular}

From the tables above it is apparent that both Australia and New Zealand have focused their attention in Asia. This decision complies with their economic interests. The Asian 
market is the most important export destination for both Australia and New Zealand. In the lists of Australia and New Zealand's trade partners, both of them have 10 Asian countries or regions in the top 15 range. Furthermore, Asia is the nearest continent to the isolated Oceania. Geographic considerations are another explanation for the close trade relationship between Asia and Oceania. Although this influence is increasingly limited due to the development of modern transportation, the natural geographic proximity remains important in the relationship of trade because the low cost of transportation can improve the competitiveness of products. For instance, ASEAN is the most convenient region in Asia to trade with Australia and New Zealand. The importance of ASEAN for Australia and New Zealand is not only seen in the ASEAN-Australia-New Zealand FTA, but also from the series of FTAs that Australia and New Zealand signed with the countries from ASEAN independently.

Both Australia and New Zealand are resource-rich countries but net importers of petroleum. They have the same energy-exporting partner as China does, namely GCC in west Asia. Other than the consideration of important trade partners and energy suppliers, maintaining a balance among different continents is another consideration in Australia's and New Zealand's RTA strategies. Australia's RTA web covers Oceania, Asia, North America and Latin America. New Zealand's RTA web has not developed as much as Australia's but still covers Oceania, Asia and Latin America. Although neither Australia nor New Zealand is involved in an FTA with European countries, both of them have been members of the Organization for Economic Co-Operation and Development (OECD) for nearly forty years. 
Australia and New Zealand have deep connections with Europe both economically and socially.

\subsubsection{The RTA Web of China, Australia and New Zealand}

Figure 8 on the next page shows that China, Australia and New Zealand have already formed their own hub \& spoke systems and that each is a hub country in their own right. However, the three RTA systems of China, Australia and New Zealand overlap each other and form an RTA web. China, Australia and New Zealand choose some of the same spoke countries. That situation gives those spoke countries the position of a hub-country. Consequently, the overlapped hub \& spoke systems decrease the benefit of China, Australia and New Zealand as hub countries. Complex RTA webs "can create a nightmarish tangle of administrative procedures that raise costs for enterprises and for governments" (Baldwin 1994, 108). The increased administrative cost is ascribed to the Rules of Origin that every FTA requires. Even though the gains of the hub \& spoke system are reduced by the formation of the RTA web, participating in the system still benefits these economies more than drifting away from the system. 


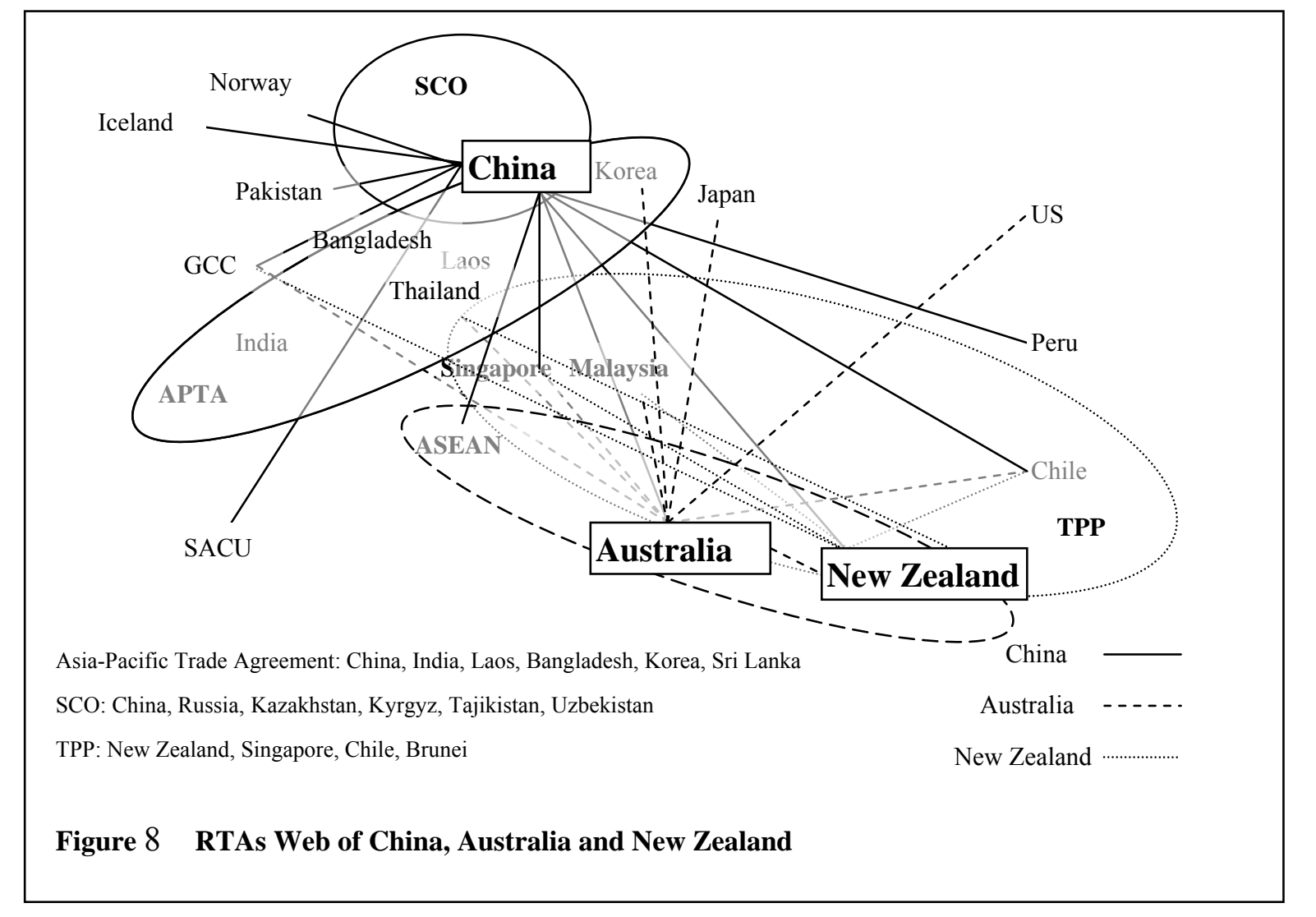

One general feature in China, Australia and New Zealand RTA strategies is that they all focus on Asian countries. China, Australia and New Zealand are members of Asia-Pacific Economic Cooperation (APEC). This indicates that China, Australia and New Zealand have common interest in Asia and that the FTAs between them will reinforce these connections. In addition, the China-New Zealand FTA and the negotiation of the China-Australia FTA show the determination of these governments to cooperating and developing the Asia-Pacific area.

Another common feature of the RTA strategies of China, Australia and New Zealand is that each country chooses both developing and developed partners in their hub \& spoke systems. Every country has its special factor endowment and different competitive advantages. The international division of labour is influenced by both geographic factors 
and economic factors. Economic factors include the degree of economic development and the economic structure of a country. As a result, one country participates in the international division of labour at different levels and with different ways simultaneously. That means, establishing FTAs with different structures (the North-North FTA and the North-South FTA for the developed country, the North-South FTA and the South-South FTA for the developing country) benefits a hub country in both directions.

From the perspective of the country in the South, it could participate in the international division of labour with a competitive advantage on labour-intensive products in the North-South production system. At the same time, the country in the South could also participate in the international division of labour with the competitive advantage on capital-intensive products in the South-South production system even though the capital-intensive advantage of the country in the South may have only just begun to take shape.

Accompanying the operation of a North-South FTA, the inflow of FDI from a developed country helps to improve the industry structure of the developing country. The absorption of the technology and the administrative experience which comes from FDI promotes the efficiency of the developing country in the production of capital-intensive or technology-intensive products. This improvement in the developing country creates a competitive advantage in capital or technology intensive production compared to other developing countries. 
From the perspective of a country in the North, the benefit of building a North-North FTA and a North-South FTA simultaneously is threefold. Firstly, a North-North FTA expands intra-industry trade between the developed countries with the same competitive advantages. The competition in the FTA increases product differentiation and the competitiveness inside the industry. Secondly, in a North-South FTA the developed country can participate in the international division of labour with its capital and technology intensive advantages. That means the developed country can occupy the upper reaches of the industry chain in the system of international division of labour with the developing countries. The upper reaches of the industry chain confers not only a high rate of return but also gives the initiative to control the industry. Finally, a North-South FTA can also give the developed country access to the markets of the developing countries which are usually protected by high tariffs or non-tariff measures.

To conclude, China, Australia and New Zealand intend to establish their own hub \& spoke systems and take hold of the gains as the hub country. Although the RTA web decreases their benefits as hub countries, the effects of the system are still considerable for China, Australia and New Zealand. It is necessary to build RTAs with both developed and developing countries for the sake of further development. It should also be noticed that China, Australia and New Zealand now have the means to upgrade their domestic industries and improve their industry structures with the help of foreign resources. Overall, the RTA web creates a complex web of trade agreements that China, Australia and New Zealand are each benefiting from through increased trade, investment and greater competition enhancing each others competitiveness. 


\subsection{The Insurance Effect of the China-New Zealand FTA and the China-Australia FTA during the Economic Crisis}

In early 2008, the sub-prime mortgage turmoil in the United States developed into a global economic crisis. The crisis has already slowed down the economic development of the world. It is predicted that the growth rate of the world output would decrease to $3.0 \%$ in 2009. The GDP growth rate of the developed economies would be $0.5 \%$ and most of them would even have negative growth rates. 2009 will be the most stressful period of the post-war period. The situation for emerging and developing economies should be much better with a growth rate of $6.1 \%$. China is estimated to be in an even better situation with a growth rate of the output of China would be $9.3 \%$ in year 2009 (IMF 2008).

Emerging and developing economies will be the major force resisting the crisis created in the centre of the global financial system because the real economy is still dominant in the economic systems of the emerging and developing countries. ${ }^{24}$ So far the international economic organisations have not had any excellent results resisting the crisis. Although the crisis has driven the restart of the WTO talks, multilateral negotiation and consensus rule need a lot of time to finish and an even longer time to show any effect. In contrast, the bilateral FTAs and regional agreements react to the economic crisis more directly because of the much smaller scale in mechanisms and the greater institutional agreements.

The importance of RTAs is apparent in this global economic crisis. Specifically, it is the Insurance Effect (Fernández and Portes 1998) of the North-South FTAs that will help

\footnotetext{
${ }^{24}$ The real economy involves the economic activities which are based on material production and circulation. Finance is in the category of virtual economy which is based on the real economy.
} 
buffer the RTA members from the worst effects of the global downturn. There are two important reasons for this. Firstly, the members of the FTA can not impute damages to its trade partners by raising protection measures on their own market. The agreement will maintain the good trade environment during the economic crisis. Without the constraints of the agreement, the trade protection measures would most likely be the first choice for most of the countries suffering the effects of the economic crisis. Furthermore, trade protection of one country would most likely cause retaliatory reactions by the other trade partners. This series of actions would deteriorate every country's situation in the economic crisis and this shows the importance of the FTAs

Secondly, the members of the FTA will rely less on outside markets due to market integration inside the free trade area. Under the circumstances of economic crisis, the developed countries would face an unsettling economic recession. Compared to the advanced economies, the outputs of the developing countries would be more stable with relatively high growth rates. Because of the FTA, the developing countries will help to drive economic growth of the developed countries through the combined markets throughout the economic crisis.

Specifically in regard to the China-New Zealand FTA and the China-Australia FTA, the insurance effect should work in both of the North-South FTAs throughout the economic crisis. China is a developing country with a huge market and a 9\% of GDP growth rate as well as a new policy of encouraging consumption. Under these conditions the China-New Zealand FTA, which guarantees greater access to Chinese markets, is insurance for New 
Zealand throughout the economic crisis. Although the China-Australia FTA is still under negotiation, it is unlikely that China will raise protection measures against Australia during the crisis because of the importance of this FTA for China. The import from New Zealand and Australia are mainly non-flexible resources that will probably be sustained around the normal level. This situation will help New Zealand and Australia to maintain their exports. At the same time, the exports of China to New Zealand and Australia are mainly low priced daily products such as clothing and shoes. These low price products help increase the consumer surplus during the economic crisis.

To conclude, the insurance effect of the North-South FTAs throughout the economic crisis is important for the developed country members. On the other hand, the economic crisis can also be a big opportunity for the development of the China-New Zealand FTA and the negotiation of the China-Australia FTA as well as the security of open markets in the developed world for China.

\subsection{The Meaning of the China-New Zealand FTA and the China-Australia FTA}

When China established its RTA strategy, the first step was to create agreements with the developing neighbours of China. The North-South FTAs are the second step. The China-New Zealand FTA and the China-Australia FTA are the main parts of this step.

Choosing New Zealand as the first developed partner to build the North-South FTA is an expected choice for China. New Zealand is an advanced economy with deep political and 
social connections with the European countries. However, New Zealand is independent from the economic circles of the European Union and the United States. In this case, New Zealand is a perfect wedge between China and the developed economies. Australia is in a similar situation but with a larger economic scale. The smaller advanced economy of New Zealand is therefore the most suitable for the first trial agreement because the inevitable negative impacts of the North-South FTA will be acceptable for China under the circumstances of small economic scale. On the other hand, the fastest economic growth of China and the biggest developing market are good reasons for New Zealand to join in the China-New Zealand FTA. Another reason is that China is a good economic ally for New Zealand and the China-New Zealand FTA could help New Zealand to avoid negative status in the competition with other Asian countries. As a result, the China-New Zealand FTA is the first North-South FTA for China.

The importance of the China-New Zealand FTA is not shown in how the FTA affects GDP growth but in what China can learn from the FTA. The first comprehensive North-South FTA will give China great experience in how to cooperate with the developed countries in the sensitive agriculture and cattle husbandry areas. The FTA could also help China to make some progress in service industries. Furthermore, the significance of the China-New Zealand FTA is in giving an example for all the other North-South FTAs of China that may follow.

Australia is also a developed economy which is independent from the economic circles of the European Union and the United States. The special international status of Australia 
makes the China-Australia FTA an important one for the RTA strategy of China as well. The difficult negotiation between Australia and China will give China more experience at negotiating with larger advanced economies and also provide a model for future North-South FTAs between China and developed economies of scale.

Both the China-New Zealand FTA and the proposed China-Australia FTA are significant developments for the consolidation of the economic and political status of China, Australia and New Zealand in the Asia-Pacific region. The final chapter will overview the major findings of this research and discuss the significance of these findings for the theoretical models introduced earlier before concluding the discussion of the significance of these North-South FTAs for China, New Zealand, Australia and the Asia Pacific Region. 


\section{Conclusion}

Thie research has developed a model of assessing the economic impact of north-south FTAs that incorporates dynamics effects of traditional gains and non-traditional gains in assessment, using the cases of China's FTAs with New Zealand and Australia. This research has not only argued the importance of the understanding of the real economic impact of the North-South FTAs, but also provided a research framework for their assessment.

The major findings of this research are that in the North-South FTAs both developing countries and developed countries benefit more from the dynamic effect and the non-traditional gains than static effect. Robson's three-country static model shows that the trade creation effect exists in North-South FTA. Both the Northern member and the Southern member benefit due to the FTA and even the outside world benefits from the North-South FTA. The dynamic effects of the North-South FTAs are mainly the competition effect and investment creation. The results of RCA and TC indexes show that the competitive effect stimulates further development of the strong industries of China, New Zealand and Australia and the vulnerable industries suffer negative impacts. The industries reinforced are New Zealand's cattle husbandry and forestry, Australia's agriculture and mining and China's textiles and manufacturing. Furthermore, some services categories of New Zealand and Australia will also have further development on China's market. On the contrary, the industries that China will be challenged are exactly the ones which New Zealand and Australia will further develop, and vice versa. 
The competitive effect which derives from market integration and the liberalisation of trade will help China improve the industry structure. The negative impacts on the vulnerable industries create an opportunity for China to restructure and redevelop them through knowledge transfer from the experience from the Northern partners. Furthermore, investment creation in the North-South FTAs will bring China bi-directional technology spill over effects which will help China improve the technology progress.

The non-traditional gains of the North-South FTA were mainly in the area of the RTA strategies of China, New Zealand and Australia and the insurance effect under the economic crisis. Based on the hub \& spoke theory, China, New Zealand and Australia take the positive attitudes to structure their own hub \& spoke systems and compete to be the hub countries. The hub country will seize a much bigger proportion of the benefits than the spoke country in the FTA. However, this research found that the hub \& spoke systems of China, New Zealand and Australia overlap each other and form an RTA web. The formation of the RTA web reduces the benefit of the hub country but the system is still dominant and leads to greater development. It was also found that China, New Zealand and Australia choose the RTA members based on considerations of important trade partners, energy sources and the balance among continents. Furthermore, they all build FTAs with different structures, the North-North and the North-South FTAs for the developed country, the South-South and the North-South FTAs for the developing country. It was found that the double-structure FTAs introduce better participation in the international division of labour for both the developed and the developing countries. 
The global economic crisis slows down economic development, especially for the advanced economies. However, the Asian developing economies will remain the engine of the global economy during the crisis. This research found that FTAs restrict trade protection measures, which is a guarantee for the sound trade between the members during the economic crisis. In addition, the China-New Zealand FTA and the proposed China-Australia FTA will serve the Northern countries by opening a stable Southern market with huge consumption potential. Therefore, the insurance effect of the North-South FTA will help the developed countries to stabilize economic conditions.

The China-New Zealand FTA and the China-Australia FTA are important parts in the RTA strategy of China. This research has found that they not only bring China economic benefits but also set an example for future North-South FTAs that China may negotiate. The North-South FTA is a relatively new form in the regional integration family. Under the circumstances of general development of multilateral trade, whilst both the Northern and the Southern members can not benefit greatly from the static effects this research highlighted that when we pay attention to the dynamic effect and non-traditional gains, the economic impact of the North-South FTAs is more significant. The economic impacts of the North-South FTAs are not only limited to trade expansion but also in the industrial restructuring and international relations of the member countries. Both the developed and developing members can promote their domestic economic development and resist the uncertainty of the multilateral trade system through these North-South RTAs. 
These findings are important for the existing theories on RTAs, FTAs and North-South RTAs in particular. They show that the static effect is no longer the main reason to build RTAs. The dynamic effect is more likely to promote economic vitality and development, and non-traditional gains have significant diplomatic and political meaning making them the main considerations for both the developed and developing economies to pursue RTAs especially the asymmetric North-South FTAs. Furthermore, different from the traditional theories of RTAs, in the North-South FTA the country in the South turns their passive status to an active status. Accompanying the changing international economic situation, the developing countries utilise their great economic growth, economic vitality and sensitive political status to attract developed countries to sign RTAs with them. The developing countries maximise their economic and political interests by using the advanced economic and political institutions and experiences from the North-South FTAs. As a result, the North-South FTA becomes a double-win instrument for both the developed and developing countries.

These findings also suggest that future research should focus on the dynamic effects and the non-traditional gains of FTAs which are more accurate indicators of the real economic impacts of FTAs.

In conclusion the findings of this research have shown that when analysing FTAs it is important to look beyond the static effects of trade liberalisation and incorporate into the analysis dynamic effects and the non-traditional gains. Analysis with dynamic effects and 
non- traditional gains incorporated provides a more accurate and realist way to explain the overall influence of the FTA on the economy and polity of both North and South partners. 


\section{Bibliography}

Australian Government Department of Foreign Affairs and Trade. Free Trade Agreements. 2009. Accessed March 29, 2009 at http://www.dfat.gov.au/trade/ftas.html.

Australian Government Department of Foreign Affairs and Trade and China Ministry of Commerce. Australia and China Free Trade Agreement Joint Feasibility Study. 2005. Accessed October 21, 2008 at http://www.dfat.gov.au/geo/china/fta/feasibility full.pdf

Bai, Dangwei, and Ligao Cheng. 2003. “Assessing the Non-Traditional Gains From FTA and its Application on East Asia". World Economy 03(6):65-69.

Balassa, Bela. 1961. The Theory of Economic Integration. Homewood, Ill., R. D. Irwin.

Balassa, Bela. 1965. "Trade Liberalization And Revealed Competitive Advantage" The Manchester School of Economic and Social Studies 33(2): 99-123.

Baldwin, Richard E. 1994. Towards an Integrated Europe. Peter Johns CEPR

Baldwin, Richard. 2003. Economic Geography and Public Policy. Princeton University Press.

Bhagwati, Jagdish. 1992. "Regionalism versus Multilateralism” paper presented at a World Bank Conference.

British Petroleum. BP Statistical Review of World Energy. 2008. Accessed March 21, 2009 at

http://www.bp.com/liveassets/bp_internet/globalbp/globalbp_uk_english/reports_and publications/statistical_energy_review_2008/STAGING/local_assets/downloads/pdf/st atistical_review_of_world_energy_full_review_2008.pdf

Central Intelligence Agency. The World FactBook. 2009. Accessed June 05, 2009 at https://www.cia.gov/library/publications/the-world-factbook/rankorder/2001 rank.html.

Chen, Shiyi, and Zhichun Yin. 2008. "Dynamic Effect of China Building FTAs: Long Term Equilibrium and Short Term Adjustment". World Economy and Politics 08(3):47-57.

China Ministry of Commerce (MOFCOM)

China Communications Development Report. 2008. Accessed October 22, 2008 at http://tradeinservices.mofcom.gov.cn/index.do?method=noCacheView\&id=51504 
China Financial Development Report. 2008. Accessed October 15, 2008 at http://tradeinservices.mofcom.gov.cn/index.do?method=noCacheView\&id=58465 Country Report of Australia. 2008. Accessed February9, 2009 at http://countryreport.mofcom.gov.cn/record/qikan.asp?id=1118; Country Report of Australia. 2007. Accessed August13, 2008 at http://countryreport.mofcom.gov.cn/record/qikan.asp?id=528; Country Report of New Zealand.2008. Accessed February6, 2009 at http://countryreport.mofcom.gov.cn/record/qikan.asp?id=1111; Country Report of New Zealand. 2007. Accessed August28, 2008 at http://countryreport.mofcom.gov.cn/record/qikan.asp?id=568; China Trade in Services Development Report. 2008. Accessed October 13, 2008 at http://tradeinservices.mofcom.gov.cn/g/2008-06-13/48292.shtml;

Foreign Market Access Report-Australia. 2008. Accessed September 24, 2008 at http://gpj.mofcom.gov.cn/accessory/200805/1210068880705.pdf;

Foreign Market Access Report-New Zealand. 2008. Accessed September 24, 2008 at http:/gpj.mofcom.gov.cn/accessory/200805/1210069076322.pdf.

Statistical Bulletin of China's Outward Foreign Direct Investment. 2007. Accessed October 30, 2008 at http://hzs.mofcom.gov.cn/accessory/200809/1222502733006.pdf. China Ministry of Commerce and New Zealand Government Ministry of Foreign Affairs and Trade. A Joint Study Report on a Free Trade Agreement between China and New Zealand. 2004. Accessed September 1, 2008 at http://www.mfat.govt.nz/downloads/trade-agreement/china/chinanzftastudy.pdf Free Trade Agreement between Government of The People's Republic of China and The Government of New Zealand. 2008. Accessed October 15, 2008 at http://www.chinafta.govt.nz/1-The-agreement/2-Text-of-the-agreement/index.php China Ministry of Land and Resources Communique on Land and Resources of China 2007. 2008. Accessed December 12, 2008 at http://www.mlr.gov.cn/wszb/20090331bzzbhxdzzk/beijingziliao/200903/t20090331_1 $\underline{17345 . h t m}$ 
Communique on Land and Resources of China 2006. 2007. Accessed December 12, 2008 at http://www.gov.cn/gzdt/2007-07/03/content_670789.htm

China United Steel Web. 2009. Accessed March 12, 2009 at http://www.custeel.com/1002/1002003/1002003_1037.shtml.

Corden, W M. 1972. "Economies of Scale and Customs Union Theory". The Journal of Political Economy 80(3):465-475.

Dunning, J. H. 1998. "Globalization and New Geography of Foreign Direct Investment". Oxford Development Studies 26(1): 47-69.

Fernández, Raquel, and Jonathan Portes. 1998. "Returns to Regionalism: An Analysis of Nontraditional Gains from Regional Trade Agreements". The World Bank Economic Review 12(2):197-220.

Gao, Cheng. 2008. "An Analysis on Asymmetric Dependence of the Trade between Australia and China" Journal of Contemporary Asia-Pacific Students 08(2):105-123.

Hoekman, Bernard. 2005. "Designing North South Trade Agreements to Promote Economic Develop". World Bank Working Paper. [Online]. 2005 [Cited September, 2008]. Available from

http://www.gem.sciences-po.fr/content/publications/pdf/Hoekman_North_South_PTA s.pdf

International Monetary Fund. World Economic Outlook. 2008. Accessed October, 2008 at http://www.imf.org/external/pubs/ft/weo/2008/02/pdf/text.pdf.

Kokko, Ari. 1993. "Technology, market characteristics, and spillovers". Journal of Development Economics 43(1994): 279-293.

Krugman, Paul R.1981. "Intra-industry Specialization and the Gains from Trade". The Journal of Political Economy 89(5):959-973.

Krugman, Paul R. 1980. "Scale Economies, Product Differentiation, and the Pattern of Trade". The American Economic Review 70(5):950-959.

Li, Li, Bingjia Shao, and Xun Cheng. 2008. "Quantitive Analysis on the Impact of China-New Zealand FTA on Both Sides' Economies". International Trade Issues 08(3):49-54.

Li, Xiangyang. 2002. "Regional Economic Cooperation in the Era of Globalization". World Economic 02(5):3-9. 
Liu, Chengyang. 2006. China Joining in the Mutual FTAs. Nankai University Press.

Mai, Yinhua, Philip Adams, Mingtai Fan, Ronglin Li and Zhaoyang Zheng. 2005

"Modelling the Potential Benefits of an Australia-China Free Trade Agreement". Working paper No.G-153

National Bureau of Statistics of China. 2009. Accessed March 10, 2009 at http://www.stats.gov.cn/tjsj/qtsj/gjsj/2007/t20080626_402488340.htm.

New Zealand Ministry of Foreign Affairs \& Trade, Trade Agreements. 2009. Accessed March 29, 2009 at http://www.mfat.govt.nz/Trade-and-Economic-Relations/Trade-Agreements/index.php New Zealand Ministry of Foreign Affairs \& Trade, Trade Agreements, China-New Zealand FTA, More about the agreement, Key outcomes. 2008. Accessed December 03,2008 at http://chinafta.govt.nz/1-The-agreement/1-Key-outcomes/1-Goods/index.phphttp://chi nafta.govt.nz/1-The-agreement/1-Key-outcomes/2-Services/index.php.

http://chinafta.govt.nz/1-The-agreement/1-Key-outcomes/3-Investment/index.php OECD database, Statistic Portal, Country profiles. 2008. Accessed January 10, 2009 at http://stats.oecd.org/WBOS/Index.aspx?DatasetCode=CSP2008

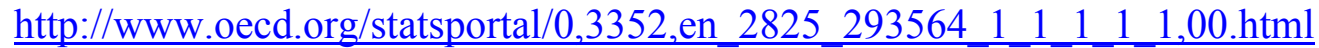

Peterson, John and Richard Barras. 1987. "Measuring International Competitiveness in Service" The Service Industries Journal 7(2): 131-142

Robson, Peter. 1987. The Economics of International Integration. Allen \& Unwin Publisher.

Statistics New Zealand. 2008. Accessed November 29, 2008 at http://www.stats.govt.nz/default.htm

Su, Xuechuan. 2006. "South-South Cooperation or North-South Cooperation?----The Choice of Developing Countries in International Regional Economic Integration" Economic Survey 35(3):35-37.

Sun, Yuhong. 2007. Global FTAs Net and Regional Integration Strategy of Developing Countries. University of International Business and Economics Publisher.

United Nations Commodity Trade Statistics Database, Data Availability, interactive. 2008. Accessed November 2, 2008 at http://comtrade.un.org/db/mr/daInteractive.aspx. 
United Nations Conference on Trade and Development, Handbook of Statistics Online, International Trade in Services. 2008. Accessed February 18, 2009 at http://stats.unctad.org/Handbook/TableViewer/tableView.aspx

Viner, Jacob. 1950. The Customs Union Issue. The Carnegie Endowment for International Peace.

Vollrath, T.L. 1991. “A Theoretical Evaluation of Alternative Trade Intensity Measures of Revealed Comparative Advantage" Review of World Economics 127(2):265-280.

Wang, Weiwei. 2007. "A Study on Growth Effects of Regional Economic Integration and Model Selection" Doctor Pater Submitted to University of International Business and Economics.

Wonnacott, Ronald J. 1996. "Trade and Investment in a Hub-and-Spoke System Versus a Free Trade Area". World Economy 19(3):237-252.

World Trade Organization, Trade Topics, Regional Trade Agreements. 2009. Accessed March 28, 2009 at http://www.wto.org/english/tratop_e/region_e/region_e.htm.

World Trade Organization, The WTO, Key Publications, International Trade Statistics, Statistics Database, Tariff Profiles. 2008. Accessed December, 2008 at http://stat.wto.org/TariffProfile/WSDBTariffPFView.aspx?Language $=\mathrm{E} \&$ Country $=\mathrm{C}$ $\underline{\mathrm{N}}$

http://stat.wto.org/TariffProfile/WSDBTariffPFView.aspx?Language=E\&Country $=\mathrm{A}$ $\underline{\mathrm{U}}$.

WSDB (WTO Statistics Database), Time series on international trade. 2008. Accessed November 10, 2008 at http://stat.wto.org/StatisticalProgram/WSDBStatProgramHome.aspx? Language=E.

Yang, Jun, Jikun Huang and Huanguang Qiu. 2005. "On the Economic Effect of Setting up the China-Australia Free Trade Area and Policy Suggestions". International Trade Issues 05(11):65-70.

Yu, Youwei, Yuju Li and Xiaowen Chen. 2006. "On the Non-equilibrium and Trade Expansion Between China and Australia". International Economics and Trade Research 22(3):24-26.

Zhang, Hong. 2006. Regional Integration and the Cooperation of East Asia. The People Press. 
Zhou, Shudong, Qiang Wu, Bingchuan Hu and Qifeng Cui. 2006. "Economic Effects of the China-Australia FTA". Agricultural and Technical Economy 06(6):19-23. 


\section{Appendixes}

\section{Appendix 1}

\section{Major Exports from New Zealand to China by Commodity (HS2002)}

unit: US dollars

\begin{tabular}{|c|c|c|c|c|c|c|}
\hline HS & Commodity & 2003 & 2004 & 2005 & 2006 & 2007 \\
\hline 01 & Live animals & $8,282,416$ & $59,966,010$ & $9,539,884$ & $2,428,832$ & $5,680,433$ \\
\hline 02 & Meat and edible meat offal & $36,900,423$ & $33,682,106$ & $33,541,912$ & $33,412,900$ & $51,861,034$ \\
\hline 03 & Fish and crustaceans, molluscs and other aquatic invertebrates & $26,444,241$ & $60,085,890$ & $79,421,416$ & $63,570,315$ & $68,233,529$ \\
\hline 04 & Dairy produce; birds eggs; natural honey & $178,675,463$ & $231,426,960$ & $211,793,717$ & $248,750,052$ & $288,046,546$ \\
\hline 05 & Products of animal origin, not elsewhere specified & $45,904,324$ & $55,885,260$ & $61,710,589$ & $55,285,186$ & $60,166,429$ \\
\hline 06 & Live trees and other plants & 212,249 & 887,116 & 858,005 & 291,756 & $1,920,613$ \\
\hline 08 & Edible fruit, nuts, peel of citrus fruit, melons & $3,504,355$ & $3,786,993$ & $6,656,677$ & $11,551,550$ & $13,935,649$ \\
\hline 12 & Oil seeds and oleaginous fruits & 773,494 & $1,156,827$ & $2,017,793$ & $3,868,101$ & $2,637,466$ \\
\hline 15 & Animal or vegetable fats and oils & $29,150,914$ & $43,333,633$ & $36,817,795$ & $41,753,201$ & $64,418,617$ \\
\hline 19 & Preparations of cereals, flour, starch or milk; bakers' wares & $5,612,657$ & $13,676,562$ & $39,044,125$ & $47,642,282$ & $63,270,259$ \\
\hline 21 & Miscellaneous edible preparations & $2,513,914$ & $3,678,004$ & $2,554,267$ & $3,197,650$ & $5,005,226$ \\
\hline 22 & Beverages, spirits and vinegar & 286,018 & 343,151 & $1,128,486$ & $1,206,502$ & $1,703,423$ \\
\hline 23 & Residues and waste from the food industries & $19,861,348$ & $21,199,913$ & $17,230,385$ & $18,735,860$ & $18,935,590$ \\
\hline 26 & Ores, slag and ash & $7,166,952$ & $20,893,783$ & $45,291,014$ & $25,951,345$ & $20,515,414$ \\
\hline 33 & Essential oils and resinoids; perfumery, cosmetic or toilet preparations & 434,863 & 137,356 & 237,250 & 964,853 & $1,601,520$ \\
\hline 35 & Albuminoids, modified starches, glues, enzymes & $7,839,227$ & $13,718,238$ & $16,079,028$ & $31,103,446$ & $28,909,804$ \\
\hline 39 & Plastics and articles thereof & $2,616,189$ & $3,045,568$ & $3,564,646$ & $4,566,296$ & $9,467,846$ \\
\hline 41 & Raw hides and skins (other than fur skins) and leather & $58,597,908$ & $61,751,162$ & $52,375,445$ & $45,805,533$ & $79,368,176$ \\
\hline 43 & Fur skins and artificial fur, manufactures thereof & $2,594,461$ & $2,133,444$ & $1,802,700$ & $1,537,482$ & $2,021,385$ \\
\hline 44 & Wood and articles of wood, wood charcoal & $112,373,188$ & $107,389,087$ & $107,445,082$ & $158,195,739$ & $173,037,221$ \\
\hline 47 & Pulp of wood or of other fibrous cellulose material & $47,932,461$ & $107,060,486$ & $95,811,563$ & $103,076,280$ & $158,318,529$ \\
\hline 48 & Paper and paperboard; articles of paper pulp, of paper or of paperboard & $17,981,889$ & $21,588,241$ & $22,206,561$ & $22,460,315$ & $24,660,1$ \\
\hline 51 & Wool, fine or coarse animal hair; horsehair yarn and woven fabric & $83,980,772$ & $102,232,630$ & $113,013,531$ & $120,736,100$ & $128,270,865$ \\
\hline 72 & Iron and steel & $4,650,823$ & $4,330,640$ & $7,303,458$ & $11,692,385$ & $11,128,944$ \\
\hline
\end{tabular}




\begin{tabular}{|c|c|c|c|c|c|c|}
\hline 73 & Articles of iron or steel & $1,639,457$ & $3,004,773$ & $4,794,889$ & $3,332,970$ & $5,244,694$ \\
\hline 74 & Copper and articles thereof & $5,491,044$ & $8,294,619$ & $17,684,741$ & $28,508,337$ & $29,350,790$ \\
\hline 76 & Aluminium and articles thereof & $13,297,268$ & $18,176,073$ & $14,157,357$ & $19,249,108$ & $18,902,356$ \\
\hline 84 & Machinery and mechanical appliances; parts thereof & $7,623,401$ & $17,256,578$ & $14,059,337$ & $18,054,802$ & $22,705,375$ \\
\hline 85 & Electrical, electronic equipment & $18,503,556$ & $20,101,922$ & $22,143,963$ & $33,237,668$ & $34,992,104$ \\
\hline 90 & Optical, photo, technical, medical, etc apparatus & 913,601 & $1,405,123$ & $1,371,304$ & $1,232,741$ & $2,472,110$ \\
\hline
\end{tabular}

Data source: UN Comtrade Database. 


\section{Appendix 2}

\section{Major Imports of New Zealand from China by Commodity (HS2002)}

\begin{tabular}{|c|c|c|c|c|c|c|}
\hline $\mathrm{HS}$ & Commodity & 2003 & 2004 & 2005 & 2006 & 2007 \\
\hline 20 & Preparations of vegetables. fruit or nuts & 8.239 .430 & 8.070 .247 & 15.530 .879 & 18.954 .446 & 29.615 .979 \\
\hline 28 & Inorganic chemicals & $24,153,869$ & $29,533,827$ & $29,927,876$ & $39,309,548$ & $38,611,141$ \\
\hline 29 & Organic chemicals & $14,222,538$ & $19,180,121$ & $29,804,730$ & $27,690,771$ & $41,231,659$ \\
\hline 31 & Fertilizers & $9,480,346$ & $17,041,186$ & $7,831,346$ & $1,876,775$ & $30,566,238$ \\
\hline 33 & Essential oils and resinoids; perfumery, cosmetic or toilet preparations & $12,161,591$ & $10,641,392$ & $11,270,241$ & $12,929,580$ & $16,980,207$ \\
\hline 39 & Plastics and articles thereof & $45,568,643$ & $64,398,005$ & $82,149,685$ & $101,018,688$ & $128,081,300$ \\
\hline 40 & Rubber and articles thereof & $13,013,721$ & $16,897,459$ & $22,549,002$ & $27,762,971$ & $41,415,448$ \\
\hline 42 & Articles of leather; saddlery and harness & $35,306,011$ & $44,052,368$ & $52,847,225$ & $55,196,911$ & $69,597,184$ \\
\hline 44 & Wood and articles of wood, wood charcoal & $5,909,604$ & $9,835,914$ & $11,873,956$ & $15,679,877$ & $18,380,366$ \\
\hline 48 & Paper and paperboard; articles of paper pulp, of paper or of paperboard & $19,380,801$ & $13,532,733$ & $40,113,315$ & $51,382,691$ & $68,330,917$ \\
\hline 49 & Printed books, newspapers, pictures and other products of the printing industry & $7,001,805$ & $11,802,727$ & $14,585,729$ & $16,711,245$ & $20,736,221$ \\
\hline 61 & Articles of apparel, accessories, knitted or crocheted & $180,626,829$ & $219,326,109$ & $258,571,711$ & $288,427,802$ & $341,210,187$ \\
\hline 62 & Articles of apparel, accessories, not knitted or crocheted & $175,979,750$ & $212,469,805$ & $238,050,092$ & $251,079,989$ & $302,495,152$ \\
\hline 63 & Other made up textile articles; sets; worn clothing and worn textile article & $45,643,909$ & $63,032,775$ & $78,043,937$ & $85,238,064$ & $100,370,905$ \\
\hline 64 & Footwear, gaiters and the like; parts of such articles & $78,955,576$ & $97,696,281$ & $115,138,318$ & $126,667,338$ & $139,967,919$ \\
\hline 69 & Ceramic products & $20,220,815$ & $23,784,557$ & $27,602,336$ & $31,282,557$ & $39,670,929$ \\
\hline 70 & Glass and glassware & $19,730,715$ & $24,464,702$ & $31,573,604$ & $44,236,376$ & $63,474,736$ \\
\hline 71 & Natural or cultured pearls, precious or semi-precious stones & $6,825,738$ & $10,187,394$ & $16,029,576$ & $19,100,320$ & $22,405,764$ \\
\hline 72 & Iron and steel & $5,513,640$ & $7,903,880$ & $9,702,582$ & $16,655,409$ & $23,555,088$ \\
\hline 73 & Articles of iron or steel & $45,335,020$ & $74,681,023$ & $92,646,071$ & $108,059,497$ & $144,368,842$ \\
\hline 76 & Aluminium and articles thereof & $6,383,789$ & $11,100,363$ & $15,510,752$ & $20,165,871$ & $27,726,913$ \\
\hline 82 & Tools, implements, cutlery, spoons and forks, of base metal & $19,038,614$ & $25,658,958$ & $27,184,080$ & $29,065,792$ & $34,645,442$ \\
\hline 83 & Miscellaneous articles of base metal & $12,099,273$ & $16,591,151$ & $20,054,452$ & $24,267,279$ & $30,547,436$ \\
\hline 84 & Machinery and mechanical appliances; parts thereof & $188,645,666$ & $301,677,565$ & $490,722,239$ & $575,854,250$ & $733,001,800$ \\
\hline 85 & Electrical machinery and equipment and parts thereof & $268,790,704$ & $354,942,180$ & $467,541,285$ & $527,795,372$ & $750,611,167$ \\
\hline 87 & Vehicles other than railway or tramway rolling stock & $25,392,297$ & $36,595,250$ & $48,221,668$ & $50,026,487$ & $66,777,416$ \\
\hline 90 & Optical, photo, technical, medical, etc apparatus & $43,411,546$ & $44,044,540$ & $61,695,381$ & $61,695,381$ & $71,928,683$ \\
\hline 94 & Furniture; bedding, mattresses, cushions and similar stuffed furnishing & $67,855,267$ & $117,843,108$ & $151,816,834$ & $170,145,646$ & $221,379,769$ \\
\hline
\end{tabular}


95 Toys, games and sports requisites; parts and accessories thereof 96 Miscellaneous manufactured articles

Data source: UN Comtrade Database.

$102,734,871$

$11,342,828$

$113,657,161$

$14,837,028$

$17,082,020$

$42,433,153$

$18,403,404$

$174,301,800$ 


\section{Appendix 3}

\section{Major Exports from Australia to China by Commodity (HS2002)}

unit: US dollars

\begin{tabular}{|c|c|c|c|c|c|c|}
\hline HS & Commodity & 2003 & 2004 & 2005 & 2006 & 2007 \\
\hline 02 & Meat and edible meat offal & $41,790,760$ & $52,208,821$ & $52,394,510$ & $42,999,681$ & $58,828,716$ \\
\hline 03 & Fish and crustaceans, molluscs and other aquatic invertebrates & $41,066,952$ & $55,707,030$ & $91,090,939$ & $56,381,232$ & $41,527,524$ \\
\hline 04 & Dairy produce; birds eggs; natural honey; & $42,722,732$ & $46,571,434$ & $40,267,987$ & $49,552,957$ & $85,299,510$ \\
\hline 10 & Cereals & $94,146,056$ & $108,793,621$ & $132,634,073$ & $174,196,036$ & $59,295,323$ \\
\hline 15 & Animal or vegetable fats and oils & $60,453,656$ & $101,199,811$ & $81,608,395$ & $85,736,423$ & $165,767,472$ \\
\hline 22 & Beverages, spirits and vinegar & $3,688,917$ & $6,254,661$ & $12,052,930$ & $29,400,795$ & $48,442,884$ \\
\hline 25 & Salt; sulfur; earths and stone; plastering materials & $7,592,884$ & $9,276,811$ & $13,430,032$ & $29,372,447$ & $44,646,071$ \\
\hline 26 & Ores, slag and ash & $1,341,756,416$ & $2,269,405,804$ & $5,382,630,209$ & $7,476,928,242$ & $9,456,158,202$ \\
\hline 27 & Mineral fuels, mineral oils and products of their distillation & $752,371,712$ & $730,695,116$ & $689,231,436$ & $738,465,284$ & $795,961,647$ \\
\hline 28 & Inorganic chemicals & $15,335,998$ & $16,371,123$ & $20,310,778$ & $22,018,090$ & $54,779,865$ \\
\hline 30 & Pharmaceutical products & $20,151,400$ & $32,648,500$ & $61,812,654$ & $108,292,607$ & $144,161,993$ \\
\hline 32 & Tanning or dyeing extracts & $99,298,376$ & $110,017,628$ & $110,825,871$ & $121,861,874$ & $116,079,936$ \\
\hline 39 & Plastics and articles thereof & $48,753,504$ & $51,343,784$ & $77,519,950$ & $83,434,556$ & $124,285,931$ \\
\hline 41 & Raw hides and skins (other than fur skins) and leather & $127,965,984$ & $161,533,480$ & $149,317,518$ & $303,038,642$ & $362,929,639$ \\
\hline 44 & Wood and articles of wood; wood charcoal & $50,787,108$ & $66,413,157$ & $87,428,461$ & $101,506,120$ & $111,638,433$ \\
\hline 47 & Pulp of wood or of other fibrous cellulose material & $5,686,613$ & $16,422,453$ & $42,321,913$ & $59,554,643$ & $104,610,392$ \\
\hline 48 & Paper and paperboard; articles of paper pulp, of paper or of paperboard & $54,256,552$ & $36,010,623$ & $37,550,298$ & $33,663,190$ & $32,362,722$ \\
\hline 51 & Wool, fine or coarse animal hair; horsehair yarn and woven fabric & $611,739,840$ & $916,628,004$ & $1,013,417,670$ & $1,042,185,197$ & $1,432,322,853$ \\
\hline 52 & Cotton & $47,306,816$ & $161,443,639$ & $287,539,480$ & $284,283,936$ & $160,200,181$ \\
\hline 71 & Natural or cultured pearls, precious or semi-precious stones & $47,306,816$ & $1,692,835$ & $77,756,220$ & $23,609,238$ & $34,647,115$ \\
\hline 72 & Iron and steel & $206,108,784$ & $128,997,545$ & $81,156,737$ & $52,500,987$ & $104,699,058$ \\
\hline 73 & Articles of iron or steel & $5,024,798$ & $4,196,926$ & $8,341,206$ & $13,692,250$ & $36,399,500$ \\
\hline
\end{tabular}


74 Copper and articles thereof

$\begin{array}{lllll}106,617,296 & 169,462,911 & 187,177,159 & 318,868,352 & 317,769,824 \\ 50,277,584 & 107,514,639 & 111,170,302 & 283,198,516 & 493,343,430 \\ 258,197,344 & 298,340,640 & 305,009,729 & 329,253,664 & 335,473,912 \\ 4,527,680 & 25,512,702 & 78,489,957 & 134,066,249 & 108,050,390 \\ 144,896,752 & 207,764,843 & 275,602,898 & 283,446,722 & 329,507,558 \\ 77,036,048 & 77,666,425 & 88,540,352 & 116,785,864 & 130,479,705 \\ 8,295,811 & 9,695,597 & 144,677,528 & 16,936,170 & 76,435,122 \\ 47,864,028 & 25,389,308 & 26,451,287 & 37,128,681 & 44,272,645\end{array}$

Data source: UN Comtrade Database. 


\section{Appendix 4}

\section{Major Imports of Australia from China by Commodity (HS2002)}

unit: US dollars

\begin{tabular}{|c|c|c|c|c|c|c|}
\hline HS & Commodity & 2003 & 2004 & 2005 & 2006 & 2007 \\
\hline 28 & Inorganic chemicals & $64,241,957$ & $80,840,996$ & $101,953,075$ & $114,997,985$ & $138,044,823$ \\
\hline 29 & Organic chemicals & $85,474,883$ & $145,381,643$ & $170,285,537$ & $197,451,746$ & $283,607,500$ \\
\hline 31 & Fertilizers & $12,426,007$ & $47,923,712$ & $56,527,002$ & $24,275,433$ & $126,134,753$ \\
\hline 39 & Plastics and articles thereof & $187,319,496$ & $370,458,130$ & $477,982,383$ & $570,751,192$ & $739,162,659$ \\
\hline 40 & Rubber and articles thereof & $53,269,398$ & $104,433,775$ & $158,680,629$ & $228,234,859$ & $299,975,258$ \\
\hline 42 & Articles of leather; saddlery and harness & $121,344,892$ & $285,132,355$ & $315,182,474$ & $340,554,498$ & $426,413,715$ \\
\hline 44 & Wood and articles of wood; wood charcoal & $31,010,486$ & $85,527,225$ & $84,123,808$ & $106,602,107$ & $141,815,124$ \\
\hline 48 & Paper and paperboard; articles of paper pulp, of paper or of paperboard & $72,956,577$ & $136,367,038$ & $178,457,206$ & $240,084,456$ & $298,256,414$ \\
\hline 49 & Printed books, newspapers, pictures and other products of the printing industry & $6,697,209$ & $62,135,882$ & $78,789,585$ & $91,457,884$ & $135,110,217$ \\
\hline 61 & Articles of apparel and clothing accessories, knitted or crocheted & $605,868,129$ & $919,832,204$ & $1,091,344,914$ & $1,189,765,680$ & $1,375,589,841$ \\
\hline 62 & Articles of apparel and clothing accessories, not knitted or crocheted & $536,976,543$ & $916,085,738$ & $1,109,037,821$ & $1,204,498,155$ & $1,307,357,064$ \\
\hline 63 & Other made up textile articles; sets; worn clothing and worn textile article & $210,559,746$ & $287,769,336$ & $318,735,661$ & $368,390,102$ & $443,857,561$ \\
\hline 64 & Footwear, gaiters and the like; parts of such articles & $149,318,029$ & $450,229,324$ & $524,928,405$ & $596,921,599$ & $661,032,929$ \\
\hline 69 & Ceramic products & $75,546,951$ & $133,723,922$ & $158,139,330$ & $178,866,119$ & $224,522,296$ \\
\hline 70 & Glass and glassware & $70,073,774$ & $110,435,809$ & $124,218,387$ & $131,701,826$ & $162,345,477$ \\
\hline 71 & Natural or cultured pearls, precious or semi-precious stones & $24,752,440$ & $62,400,547$ & $82,906,456$ & $94,037,739$ & $114,996,974$ \\
\hline 72 & Iron and steel & $20,863,886$ & $90,776,292$ & $270,582,553$ & $150,526,288$ & $254,203,105$ \\
\hline 73 & Articles of iron or steel & $226,918,831$ & $439,230,389$ & $530,534,181$ & $628,042,485$ & $913,116,667$ \\
\hline 74 & Copper and articles thereof & $5,255,285$ & $29,303,304$ & $47,511,078$ & $79,694,857$ & $107,018,841$ \\
\hline 76 & Aluminium and articles thereof & $117,234,709$ & $177,150,365$ & $214,466,748$ & $286,345,836$ & $350,671,182$ \\
\hline 82 & Tools, implements, cutlery, spoons and forks, of base metal & $62,603,886$ & $119,909,309$ & $121,780,720$ & $144,591,469$ & $168,367,950$ \\
\hline 83 & Miscellaneous articles of base metal & $39,656,545$ & $112,420,700$ & $124,852,810$ & $148,776,880$ & $196,565,537$ \\
\hline
\end{tabular}


84 Machinery and mechanical appliances; parts thereof

85 Electrical machinery and equipment and parts thereof

87 Vehicles other than railway or tramway rolling stock

89 Ships, boats and floating structures

90 Optical, photographic, cinematographic and thereof

94 Furniture; bedding, mattresses, cushions and similar stuffed furnishing

95 Toys, games and sports requisites; parts and accessories thereof

96 Miscellaneous manufactured articles

Data source: UN Comtrade Database.

\begin{tabular}{lllll}
$1,089,074,463$ & $2,385,094,856$ & $3,240,483,224$ & $3,775,156,076$ & $4,593,922,087$ \\
$857,364,004$ & $2,374,409,808$ & $2,833,891,356$ & $3,658,438,178$ & $5,110,696,730$ \\
$107,972,304$ & $218,145,078$ & $262,848,061$ & $349,928,974$ & $468,742,061$ \\
$5,547,269$ & $17,819,267$ & $54,577,757$ & $97,008,253$ & $107,752,952$ \\
$65,072,481$ & $270,994,462$ & $325,632,147$ & $320,988,473$ & $277,514,450$ \\
$271,841,040$ & $654,776,099$ & $843,915,331$ & $1,038,941,857$ & $1,277,800,456$ \\
$216,092,446$ & $695,836,810$ & $806,532,645$ & $991,011,638$ & $1,170,319,960$ \\
$26,523,983$ & $76,818,769$ & $78,899,773$ & $94,309,080$ & $108,591,285$ \\
\hline
\end{tabular}

$76,818,769$

$78,899,773$

$94,309,080$

$108,591,285$ 


\section{Appendix 5}

\section{Major Exports from New Zealand to Australia by Commodity (HS2002)}

Unit: NZ\$

\begin{tabular}{|c|c|c|c|c|c|c|}
\hline HS & Commodity & 2003 & 2004 & 2005 & 2006 & 2007 \\
\hline 01 & Live animals & $68,597,873$ & $90,113,210$ & $99,085,253$ & $85,218,792$ & $78,128,988$ \\
\hline 03 & Fish and crustaceans, molluscs and other aquatic invertebrates & $168,900,143$ & $163,002,456$ & $153,730,769$ & $175,537,353$ & $188,010,983$ \\
\hline 04 & Dairy produce; birds eggs; natural honey; & $207,238,957$ & $253,936,323$ & $260,356,105$ & $306,630,458$ & $326,109,510$ \\
\hline 07 & Edible vegetables and certain roots and tubers & $73,367,740$ & $78,470,475$ & $81,448,587$ & $93,635,185$ & $105,129,664$ \\
\hline 08 & Edible fruit and nuts; peel of citrus fruit or melons & $61,384,125$ & $72,273,697$ & $85,128,677$ & $87,871,908$ & $91,622,616$ \\
\hline 19 & Preparations of cereals, flour, starch or milk; bakers' wares & $92,462,421$ & $109,131,451$ & $128,653,432$ & $155,715,461$ & $164,320,397$ \\
\hline 20 & Preparations of vegetables, fruit or nuts & $91,011,065$ & $105,765,160$ & $92,975,579$ & $114,274,065$ & $116,465,752$ \\
\hline 21 & Miscellaneous edible preparations & $149,666,528$ & $163,558,639$ & $184,248,573$ & $199,168,554$ & $200,845,269$ \\
\hline 22 & Beverages, spirits and vinegar & $136,433,033$ & $176,845,549$ & $194,557,708$ & $257,296,445$ & $327,436,034$ \\
\hline 27 & Mineral fuels, mineral oils and products of their distillation & $270,741,878$ & $297,468,366$ & $369,397,041$ & $423,806,725$ & $1,075,867,712$ \\
\hline 34 & Soap, organic surface-active agents & $80,447,282$ & $76,022,477$ & $78,580,702$ & $67,150,091$ & $83,846,489$ \\
\hline 38 & Miscellaneous chemical products & $80,347,289$ & $99,944,279$ & $87,771,147$ & $95,735,581$ & $77,682,771$ \\
\hline 39 & Plastics and articles thereof & $256,696,862$ & $277,614,176$ & $292,772,613$ & $283,042,271$ & $282,591,045$ \\
\hline 44 & Wood and articles of wood; wood charcoal & $398,497,648$ & $394,319,866$ & $343,228,583$ & $345,025,862$ & $356,118,489$ \\
\hline 47 & Pulp of wood or of other fibrous cellulose material & $94,686,756$ & $96,092,134$ & $88,135,339$ & $108,294,529$ & $104,725,150$ \\
\hline 48 & Paper and paperboard; articles of paper pulp, of paper or of paperboard & $364,422,631$ & $281,458,284$ & $202,691,360$ & $248,488,022$ & $302,215,606$ \\
\hline 51 & Wool, fine or coarse animal hair; horsehair yarn and woven fabric & $165,079,013$ & $144,571,767$ & $124,760,153$ & $122,268,121$ & $128,295,056$ \\
\hline 57 & Carpets and other textile floor coverings & $115,465,141$ & $108,179,404$ & $104,396,037$ & $109,819,973$ & $95,132,411$ \\
\hline 61 & Articles of apparel and clothing accessories, knitted or crocheted & $70,520,034$ & $70,471,741$ & $70,657,017$ & $70,081,818$ & $73,686,495$ \\
\hline 62 & Articles of apparel and clothing accessories, not knitted or crocheted & $111,638,997$ & $120,749,098$ & $115,927,803$ & $116,247,832$ & $116,497,978$ \\
\hline 71 & Natural or cultured pearls, precious or semi-precious stones & $289,392,712$ & $318,554,755$ & $327,461,014$ & $375,724,460$ & $355,134,719$ \\
\hline 72 & Iron and steel & $132,632,187$ & $166,621,417$ & $201,000,605$ & $156,927,282$ & $202,392,021$ \\
\hline
\end{tabular}




\begin{tabular}{|c|c|c|c|c|c|c|}
\hline 73 & Articles of iron or steel & $133,213,508$ & $132,395,015$ & $113,766,837$ & $117,017,144$ & $118,603,002$ \\
\hline 76 & Aluminium and articles thereof & $100,177,772$ & $115,113,826$ & $87,253,024$ & $101,905,997$ & $115,396,250$ \\
\hline 84 & Machinery and mechanical appliances; parts thereof & $715,341,305$ & $751,246,560$ & $737,780,561$ & $785,655,024$ & $850,794,838$ \\
\hline 85 & Electrical machinery and equipment and parts thereof; sound recorders and $\mathrm{r} . .$. & $287,924,243$ & $325,413,754$ & $345,167,120$ & $397,909,044$ & $405,126,652$ \\
\hline 87 & Vehicles other than railway or tramway rolling stock & $138,975,726$ & $144,438,681$ & $143,067,675$ & $153,156,386$ & $149,543,307$ \\
\hline 89 & Ships, boats and floating structures & $169,177,141$ & $29,303,432$ & $36,845,818$ & $83,903,676$ & $82,747,577$ \\
\hline 90 & Optical, photographic, cinematographic, measuring, checking, precision, med ... & $111,976,497$ & $112,405,062$ & $121,617,470$ & $108,270,987$ & $121,005,791$ \\
\hline 94 & Furniture; bedding, mattresses, cushions and similar stuffed furnishing & $96,617,861$ & $94,663,785$ & $87,792,350$ & $98,573,315$ & $109,775,868$ \\
\hline
\end{tabular}

Data source: Statistics New Zealand. 


\section{Appendix 6}

\section{Major Imports of New Zealand from Australia by Commodity (HS2002)}

Unit: NZ\$

\begin{tabular}{|c|c|c|c|c|c|c|}
\hline HS & Commodity & 2003 & 2004 & 2005 & 2006 & 2007 \\
\hline 17 & Sugars and sugar confectionery & $119,251,898$ & $114,668,097$ & $120,907,839$ & $161,934,215$ & $129,687,466$ \\
\hline 18 & Cocoa and cocoa preparations & $64,373,439$ & $64,705,554$ & $70,721,880$ & $73,919,483$ & $85,279,066$ \\
\hline 19 & Preparations of cereals, flour, starch or milk; bakers' wares & $154,552,583$ & $158,677,270$ & $169,175,876$ & $191,969,726$ & $198,849,739$ \\
\hline 20 & Preparations of vegetables, fruit or nuts & $97,130,913$ & $90,055,996$ & $88,952,517$ & $96,884,979$ & $103,129,465$ \\
\hline 21 & Miscellaneous edible preparations & $157,628,780$ & $166,049,976$ & $162,618,948$ & $188,536,941$ & $184,476,501$ \\
\hline 22 & Beverages, spirits and vinegar & $185,425,765$ & $181,866,527$ & $189,451,348$ & $197,884,213$ & $194,421,583$ \\
\hline 23 & Residues and waste from the food industries & $64,243,872$ & $52,416,678$ & $49,741,730$ & $55,475,613$ & $72,698,012$ \\
\hline 27 & Mineral fuels, mineral oils and products of their distillation & $767,931,580$ & $1,163,457,483$ & $978,461,386$ & $1,074,423,968$ & $1,379,435,060$ \\
\hline 28 & Inorganic chemicals & $268,791,998$ & $301,319,636$ & $293,782,204$ & $399,823,290$ & $344,734,276$ \\
\hline 30 & Pharmaceutical products & $236,150,213$ & $204,790,349$ & $240,059,757$ & $263,598,330$ & $343,472,114$ \\
\hline 32 & Tanning or dyeing extracts & $104,880,783$ & $101,110,639$ & $104,708,254$ & $110,124,732$ & $123,009,818$ \\
\hline 33 & Essential oils and resinoids; perfumery, cosmetic or toilet preparations & $129,948,204$ & $118,561,926$ & $114,540,005$ & $117,001,465$ & $111,428,100$ \\
\hline 34 & Soap, organic surface-active agents & $64,500,175$ & $67,252,156$ & $69,948,570$ & $81,788,417$ & $98,115,897$ \\
\hline 38 & Miscellaneous chemical products & $73,763,076$ & $81,436,917$ & $89,202,597$ & $110,066,911$ & $120,257,851$ \\
\hline 39 & Plastics and articles thereof & $270,587,971$ & $291,304,192$ & $316,696,031$ & $328,626,088$ & $331,082,258$ \\
\hline 40 & Rubber and articles thereof & $52,397,022$ & $55,996,532$ & $55,058,992$ & $58,240,584$ & $70,640,667$ \\
\hline 48 & Paper and paperboard; articles of paper pulp, of paper or of paperboard & $423,375,133$ & $414,730,467$ & $388,759,856$ & $386,646,367$ & $386,664,060$ \\
\hline 49 & Printed books, newspapers, pictures and other products of the printing industry; & $189,821,691$ & $187,277,800$ & $190,421,052$ & $189,747,250$ & $192,487,663$ \\
\hline 71 & Natural or cultured pearls, precious or semi-precious stones & $55,200,087$ & $59,783,448$ & $64,684,517$ & $83,072,549$ & $78,634,380$ \\
\hline 72 & Iron and steel & $169,056,026$ & $238,423,686$ & $215,598,872$ & $225,023,752$ & $223,493,846$ \\
\hline 73 & Articles of iron or steel & $170,930,201$ & $199,264,607$ & $223,922,037$ & $224,123,385$ & $221,804,032$ \\
\hline 74 & Copper and articles thereof & $80,920,201$ & $81,094,664$ & $105,131,509$ & $195,003,098$ & $152,402,350$ \\
\hline
\end{tabular}


76 Aluminium and articles thereof

$139,131,780 \quad 147,606,068$

$24,073,560 \quad 26,550,570$

$139,899,770 \quad 175,379,797$

$161,292,157$

79 Zinc and articles thereof

84 Machinery and mechanical appliances; parts thereof

$549,395,297 \quad 587,229,000$

$30,503,210 \quad 63,146,565$

$67,586,415$

85 Electrical machinery and equipment and parts thereof; sound recorders and $\mathrm{r}$...

$327,891,115 \quad 391,280,251$

87 Vehicles other than railway or tramway rolling stock

$814,862,447 \quad 862,440,203$

$517,966,814 \quad 535,649,877$

$505,273,511$

89 Ships, boats and floating structures

$96,483,045 \quad 51,932,698$

$405,688,213 \quad 438,216,221$

$405,893,117$

90 Optical, photographic, cinematographic, measuring, checking, precision, med ...

$130,387,728 \quad 127,496,024$

$816,113,338 \quad 620,851,140$

$674,846,423$

$69,850,151$

$71,777,918$

$61,291,943 \quad 79,873,325$

$80,660,447$

94 Furniture; bedding, mattresses, cushions and similar stuffed furnishing

$154,214,228 \quad 150,501,886$

$153,590,224$

Data source: Statistics New Zealand. 
Appendix 7 Original Data for RCA Index

Exports to the World by Commodity (HS 2007) and Country in 2007 (1)

Unit: US\$

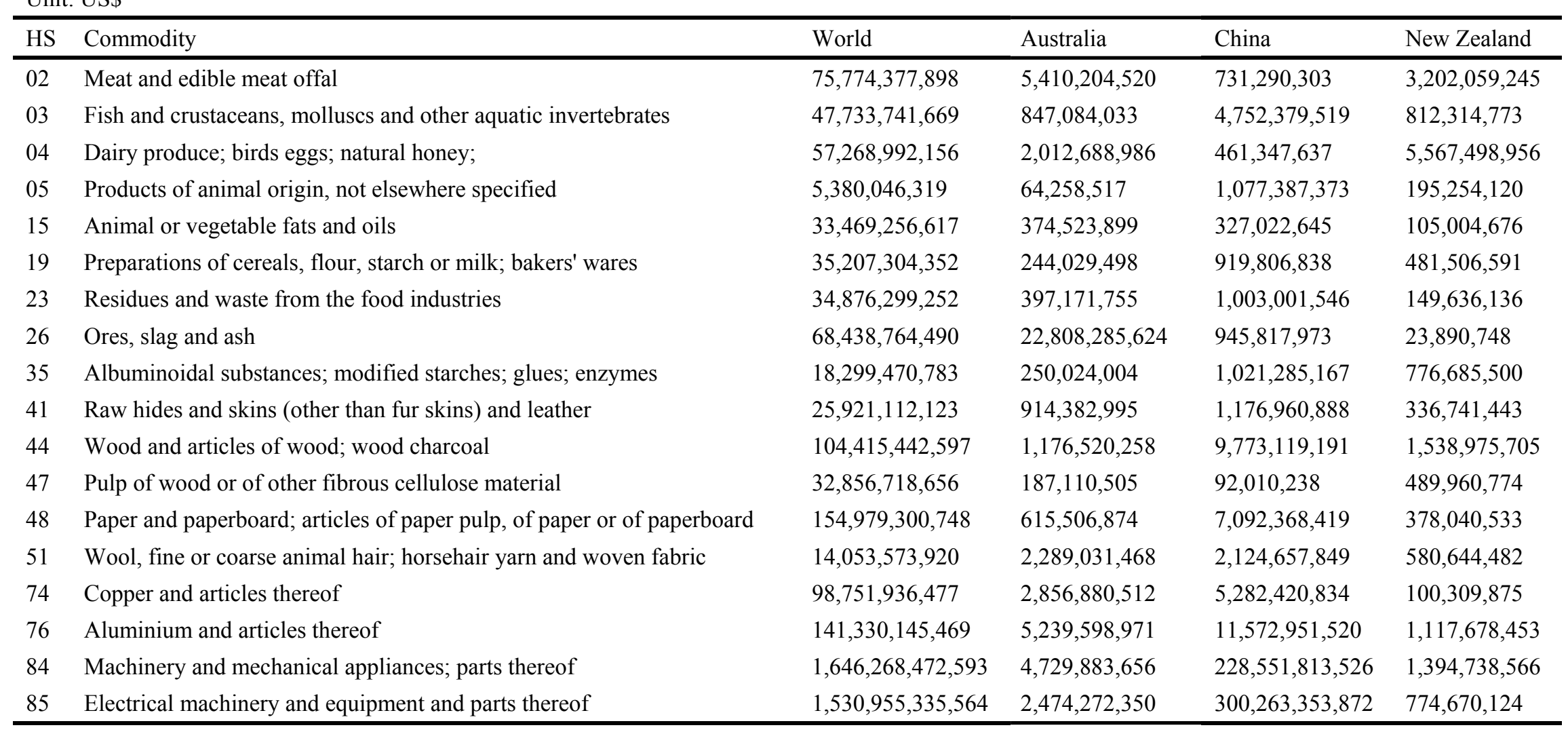

Data source: UN Comtrade Database. 


\section{Appendix 8}

Exports to the World by Commodity (HS 2007) and Country in 2007 (2)

Unit: US\$

\begin{tabular}{lllll}
\hline HS & Commodity & World & Australia & China \\
\hline 10 & Cereals & $62,916,763,598$ & $2,211,558,046$ & $1,967,047,881$ \\
27 & Mineral fuels, mineral oils and products of their distillation & $1,129,679,604,186$ & $31,647,895,684$ & $19,950,969,513$ \\
32 & Tanning or dyeing extracts & $59,662,467,935$ & $513,018,068$ & $3,577,017,498$ \\
39 & Plastics and articles thereof & $401,695,646,166$ & $935,648,206$ & $26,397,231,684$ \\
52 & Cotton & $36,068,086,057$ & $486,258,576$ & $9,358,810,392$ \\
72 & Iron and steel & $362,925,960,070$ & $1,372,852,321$ & $39,942,540,468$ \\
75 & Nickel and articles thereof & $40,747,574,036$ & $1,527,196,898$ & $695,484,016$ \\
\hline
\end{tabular}

Data source: UN Comtrade Database. 


\section{Appendix 9}

Exports to the World by Commodity (HS 2007) and Country in 2007 (3)

Unit: US\$

\begin{tabular}{|c|c|c|c|c|c|}
\hline HS & Commodity & World & Australia & China & New Zealand \\
\hline 28 & Inorganic chemicals & $86,177,254,768$ & $5,521,460,559$ & $9,661,173,118$ & $15,084,575$ \\
\hline 29 & Organic chemicals & $314,037,673,563$ & $135,915,434$ & $20,596,783,741$ & $42,616,388$ \\
\hline 42 & Articles of leather; saddlery and harness & $40,053,123,057$ & $37,654,187$ & $14,229,340,057$ & $11,783,106$ \\
\hline 48 & Paper and paperboard; articles of paper pulp, of paper or of paperboard & $154,979,300,748$ & $615,506,874$ & $7,092,368,419$ & $378,040,533$ \\
\hline 61 & Articles of apparel and clothing accessories, knitted or crocheted & $136,335,754,696$ & $80,583,063$ & $61,326,006,525$ & $77,662,799$ \\
\hline 62 & Articles of apparel and clothing accessories, not knitted or crocheted & $131,675,267,164$ & $87,012,108$ & $47,315,655,617$ & $107,298,451$ \\
\hline 63 & Other made up textile articles; sets; worn clothing and worn textile article & $30,354,797,595$ & $68,610,815$ & $13,554,900,810$ & $43,447,654$ \\
\hline 64 & Footwear, gaiters and the like; parts of such articles & $70,300,238,713$ & $36,570,174$ & $25,305,587,255$ & $43,544,359$ \\
\hline 69 & Ceramic products & $34,327,541,650$ & $71,382,123$ & $6,640,895,921$ & $5,234,617$ \\
\hline 70 & Glass and glassware & $53,619,299,262$ & $153,163,200$ & $7,148,550,719$ & $19,174,913$ \\
\hline 73 & Articles of iron or steel & $227,557,547,378$ & $713,079,996$ & $36,677,846,814$ & $204,754,526$ \\
\hline 82 & Tools, implements, cutlery, spoons and forks, of base metal & $43,772,842,190$ & $168,140,704$ & $7,186,851,292$ & $51,261,059$ \\
\hline 85 & Electrical machinery and equipment and parts thereof & $1,530,955,335,564$ & $2,474,272,350$ & $300,263,353,872$ & $774,670,124$ \\
\hline 87 & Vehicles other than railway or tramway rolling stock & $1,092,859,095,578$ & $3,438,504,474$ & $31,803,561,481$ & $194,065,026$ \\
\hline 90 & Optical, photographic, cinematographic and thereof & $358,176,142,582$ & $2,061,580,857$ & $37,061,719,563$ & $397,054,419$ \\
\hline 94 & Furniture; bedding, mattresses, cushions and similar stuffed furnishing & $143,012,910,360$ & $199,559,504$ & $35,942,020,095$ & $146,652,736$ \\
\hline 95 & Toys, games and sports requisites; parts and accessories thereof & $78,636,405,932$ & $346,265,113$ & $27,105,186,795$ & $33,095,196$ \\
\hline
\end{tabular}

Data source: UN Comtrade Database. 


\section{Appendix 10 Original Data for TC Index}

Exports and Imports of Services by Country in 2006

\begin{tabular}{|c|c|c|c|c|c|c|c|}
\hline Code & Type of Services & $\begin{array}{l}\text { Australia } \\
\text { Export }\end{array}$ & Import & $\begin{array}{l}\text { China } \\
\text { Export }\end{array}$ & Import & $\begin{array}{l}\text { New Zea } \\
\text { Export }\end{array}$ & $\begin{array}{l}\text { d } \\
\text { Import }\end{array}$ \\
\hline 200 & Total EBOPS Service & $33,088.70$ & $32,250.50$ & $91,999.20$ & $100,833.00$ & $7,873.70$ & $7,774.10$ \\
\hline 205 & 1 Transportation & $6,358.10$ & $11,334.10$ & $21,015.30$ & $34,369.00$ & $1,655.10$ & $2,585.90$ \\
\hline 236 & 2 Travel & $17,854.10$ & $11,690.20$ & $33,949.00$ & $24,321.70$ & $4,562.70$ & $2,525.90$ \\
\hline 245 & 3 Communications services & 645.5 & 644.1 & 737.9 & $42,142.40$ & 150.93 & 194.9 \\
\hline 249 & 4 Construction services & 97.2 & 0.00 & $2,752.60$ & 764.1 & 20.08 & 50.7 \\
\hline 253 & 5 Insurances services & 530.3 & 677.9 & 548.2 & $8,831.10$ & 26.6 & 211.3 \\
\hline 260 & 6 Financial services & 756.2 & 451.9 & 145.4 & 891.5 & 79.8 & 74.5 \\
\hline 262 & 7 Computer and information services & $1,061.10$ & 934.7 & $2,957.70$ & $1,738.80$ & 181.5 & 270.4 \\
\hline 266 & 8 Royalties and license fees & 621.2 & $2,221.00$ & 204.5 & $6,634.10$ & 123.5 & 486.8 \\
\hline 268 & 9 Other business services & $4,013.10$ & $2,826.30$ & $28,972.00$ & $20,605.30$ & 821.6 & $1,233.40$ \\
\hline 287 & 10 Personal, cultural, and recreational services & 502.3 & 851 & 137.4 & 121.5 & 153 & 41 \\
\hline 291 & 11 Government services, n.i.e. & 649.6 & 619.3 & 578.7 & 506.4 & 97.3 & 99.1 \\
\hline
\end{tabular}

Data source: UNCTAD Handbook of Statistics online, International trade in services, http://stats.unctad.org/Handbook/TableViewer/tableView.aspx. 


\section{Appendix 11}

Exports and Imports of Services by Country in 2005

Unit: million US\$

\begin{tabular}{|c|c|c|c|c|c|c|c|}
\hline Code & Type of Services & $\begin{array}{l}\text { Australia } \\
\text { Export }\end{array}$ & Import & $\begin{array}{l}\text { China } \\
\text { Export }\end{array}$ & Import & $\begin{array}{l}\text { New Zeal } \\
\text { Export }\end{array}$ & $\begin{array}{l}\text { Ind } \\
\text { Import }\end{array}$ \\
\hline 200 & Total EBOPS Service & $31,046.80$ & $30,504.80$ & $74,404.10$ & $83,795.50$ & $8,295.60$ & $8,213.20$ \\
\hline 205 & 1 Transportation & $6,169.60$ & $10,758.90$ & $15,426.50$ & $28,447.50$ & $1,636.30$ & $2,779.70$ \\
\hline 236 & 2 Travel & $16,868.20$ & $11,252.60$ & $29,296.00$ & $21,759.10$ & $4,865.20$ & $2,662.10$ \\
\hline 245 & 3 Communications services & 624.7 & 624.7 & 485.2 & 603.4 & 273.1 & 301.3 \\
\hline 249 & 4 Construction services & 94.5 & 0.00 & $2,592.90$ & $1,619.40$ & 54.2 & 28.1 \\
\hline 253 & 5 Insurances services & 530 & 676.6 & 549.4 & $7,199.60$ & 27.4 & 240.7 \\
\hline 260 & 6 Financial services & 763.8 & 408.3 & 145.2 & 159.5 & 87.3 & 126 \\
\hline 262 & 7 Computer and information services & 886.1 & 802.4 & $1,840.20$ & $1,622.50$ & 191.5 & 248.5 \\
\hline 266 & 8 Royalties and license fees & 552.4 & $2,004.80$ & 157.4 & $5,321.30$ & 92.2 & 551.3 \\
\hline 268 & 9 Other business services & $3,451.30$ & $2,607.20$ & $23,282.60$ & $16,286.50$ & 796.3 & $1,127.90$ \\
\hline 287 & 10 Personal, cultural, and recreational services & 437.6 & 773.7 & 133.9 & 153.9 & 169.6 & 42.9 \\
\hline 291 & 11 Government services, n.i.e. & 668.5 & 595.6 & 494.7 & 622.8 & 102 & 102.7 \\
\hline
\end{tabular}

Data source: China Trade in Services, http://tradeinservices.mofcom.gov.cn/index.shtml. 
